MARIANA DE SOUZA ARANHA GARCIA GOMES

CARACTERIZAÇÃO FENOTÍPICA DO CAMUNDONGO MUTANTE ESPONTÂNEO TREMOR UTILIZANDO UMA BATERIA DE TESTES COMPORTAMENTAIS

São Paulo

2017 


\section{CARACTERIZAÇÃO FENOTÍPICA DO CAMUNDONGO MUTANTE ESPONTÂNEO TREMOR UTILIZANDO UMA BATERIA DE TESTES COMPORTAMENTAIS}

Dissertação apresentada ao Programa de Pós-
Graduação em Patologia Experimental e
Comparada da Faculdade de Medicina
Veterinária e Zootecnia da Universidade de
São Paulo para a obtenção do título de Mestre
em Ciências

Departamento:

Departamento de Patologia

Área de Concentração:

Patologia Experimental e Comparada

Orientador:

Profa. Dra. Claudia Madalena Cabrera Mori

São Paulo 
Autorizo a reprodução parcial ou total desta obra, para fins acadêmicos, desde que citada a fonte.

\section{DADOS INTERNACIONAIS DE CATALOGAÇÃO NA PUBLICAÇÃO}

(Biblioteca Virginie Buff D’Ápice da Faculdade de Medicina Veterinária e Zootecnia da Universidade de São Paulo)

Garcia Gomes, Mariana de Souza Aranha

Caracterização fenotípica do camundongo mutante espontâneo tremor utilizando uma bateria de testes comportamentais. / Mariana de Souza Aranha Garcia Gomes. -- 2017.

$98 \mathrm{f}$. : il.

Dissertação (Mestrado) - Universidade de São Paulo. Faculdade de Medicina Veterinária e Zootecnia. Departamento de Patologia, São Paulo, 2017.

Programa de Pós-Graduação: Patologia Experimental e Comparada.

Área de concentração: Patologia Experimental e Comparada.

Orientador: Profa. Dra. Claudia Madalena Cabrera Mori.

1. Mutação espontânea. 2. Deficiência motora. 3. Ataxia. 4. Gene Egr3.

5. Doenças neurológicas. I. Título. 


\section{CERTIFICADO}

Certificamos que o Projeto intitulado "CARACTERIZAÃ $\square$ Ã $\square$ FENOTÃ $\square$ PICA DO CAMUNDONGO MUTANTE ESPONTÃ $\square$ NEO TREMOR UTILIZANDO UMA BATERIA DE TESTES COMPORTAMENTAIS ", protocolado sob o CEUA no 4124150116, sob a responsabilidade de Cláudia Madalena Cabrera Mori e equipe; Mariana de Souza Aranha Garcia Gomes; Maria Martha Bernardi; Silvia Maria Gomes Massironi - que envolve a produção, manutenção e/ou utilização de animais pertencentes ao filo Chordata, subfilo Vertebrata (exceto o homem), para fins de pesquisa científica (ou ensino) - encontra-se de acordo com os preceitos da Lei 11.794, de 8 de outubro de 2008, com o Decreto 6.899, de 15 de julho de 2009, com as normas editadas pelo Conselho Nacional de Controle da Experimentação Animal (CONCEA), e foi aprovado pela Comissão de Ética no Uso de Animais da Faculdade de Medicina Veterinária e Zootecnia da Universidade de São Paulo (CEUA/FMZV) em reunião de 23/03/2016.

We certify that the proposal "PHENOTYPIC CARACTERIZATION OF SPONTANEOUS MUTANT MICE TREMOR USING BEHAVIORAL TEST BATTERIES. ", utilizing 62 Isogenics mice (males and females), protocol number CEUA 4124150116, under the responsibility of Cláudia Madalena Cabrera Mori and team; Mariana de Souza Aranha Garcia Gomes; Maria Martha Bernardi; Silvia Maria Gomes Massironi - which involves the production, maintenance and/or use of animals belonging to the phylum Chordata, subphylum Vertebrata (except human beings), for scientific research purposes (or teaching) - it's in accordance with Law 11.794, of October 8 2008, Decree 6899, of July 15, 2009, with the rules issued by the National Council for Control of Animal Experimentation (CONCEA), and was approved by the Ethic Committee on Animal Use of the University of São Paulo (CEUA/FMZV) in the meeting of 03/23/2016.

Vigência da Proposta: de 02/2016 a 02/2018

Área: Patologia Experimental E Comparada

Procedência: Biotério do Departamento de Patologia da FMVZ USP

$\begin{array}{lllll}\text { Espécie: } & \text { Camundongos isogênicos } & \text { sexo: } & \text { Machos e Fêmeas } & \text { idade: } 8 \text { a } 18365 \quad 31 \\ \text { Linhagem: } & \text { C57BL/6 } & \text { Peso: } & 200 \text { a } 200\end{array}$

Procedência: Biotério do Departamento de Patologia da FMVZ USP

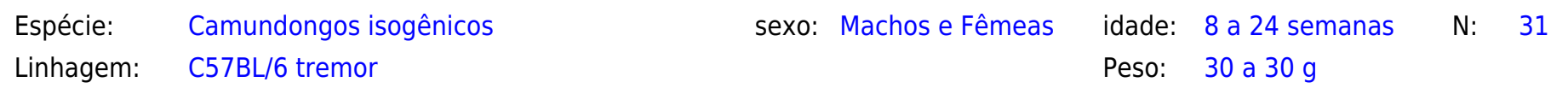

Resumo: O camundongo de laboratório é amplamente utilizado como o modelo animal na investigação de componentes genéticos e celulares que são relevantes para o entendimento de processos fisiológicos e patológicos em seres humanos e outras espécies animais. Relatos de literatura descrevem inúmeras mutações, em diferentes regiões do genoma do camundongo, causando alterações neurológicas. Esses modelos constituíram importantes ferramentas para o estudo das doenças neurodegenerativas e para o avanço dos tratamentos nas últimas décadas. A mutação espontânea tremor (tr), autossômica recessiva, foi observada na colônia de camundongos Swiss do Biotério do Departamento de Patologia da FMVZ/USP causando tremores, ataxia e convulsões. $\mathrm{Na}$ análise histopatológica evidenciou-se deficiência de mielina principalmente nas meninges e camada molecular do cerebelo. Posteriormente, realizaram-se dez retrocuzamentos com a linhagem C57BL/6 para mudança do fundo genético. Resultados preliminares do mapeamento genético, utilizando marcadores microssatélites, indicam que a mutação tremor encontra-se no cromossomo 14, possivelmente no gene Egr3 (Early Growth Response 3). A caracterização fenotípica dos camundongos mutantes será realizada pela avaliação de parâmetros comportamentais de motilidade, psicomotores, sensoriais e ligados ao sistema nervoso por meio de observação direta dos animais. Serão utilizados camundongos machos com 8 semanas de idade, sendo 20 mutantes tremor e 20 camundongos C57BL/6 que não apresentavam a mutação para o grupo controle. Inicialmente, os testes serão realizados no campo aberto e ordenados por parâmetro avaliado, na seguinte sequência: 1) atividade geral dos animais e sistema sensorial: frêmito vocal, irritabilidade, reflexo auricular, aperto de cauda, reflexo corneal e resposta ao toque; 2) testes psicomotores: contorção, trem posterior, reflexo de endireitamento, tônus corporal e força de agarrar; 3) avaliação do sistema nervoso central e autônomo: tremores, convulsões, cauda em pé, sedação, anestesia, ataxia, ptose, lacrimação, micção e defecação. Os outros testes a serem realizados envolvem: a memória e aprendizado nos testes de reconhecimento de objetos, o comportamento em labirinto em cruz elevada, comportamento no labirinto em T, a coordenação motora em trave elevada e a resposta comportamental no teste de suspensão pela cauda e nado forçado. Para a caracterização molecular desse animal serão realizados estudos mais detalhados baseados em dados da literatura e também em bases de dados, como o MGI (Mouse Genome Informatics), visando correlacionar o fenótipo do mutante tr com as alterações observadas em mutações no gene Egr3. Posteriormente, o gene candidato será sequenciado pelo método de Sanger. 


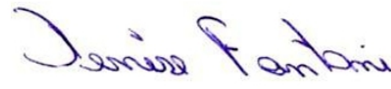

Profa. Dra. Denise Tabacchi Fantoni

Presidente da Comissão de Ética no Uso de Animais

Faculdade de Medicina Veterinária e Zootecnia da Universidade de São Paulo

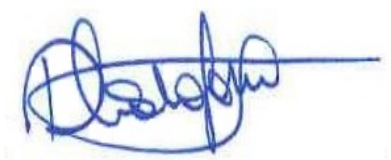

Roseli da Costa Gomes

Secretaria Executiva da Comissão de Ética no Uso de Animais Faculdade de Medicina Veterinária e Zootecnia da Universidade de São Paulo 
IImo(a). Sr(a).

Responsável: Cláudia Madalena Cabrera Mori

Área: Patologia Experimental E Comparada

Claudia Madalena Cabrera Mori (orientador)

Título da proposta: "CARACTERIZAÇÃO FENOTÍPICA DO CAMUNDONGO MUTANTE ESPONTÂNEO TREMOR UTILIZANDO UMA BATERIA DE TESTES COMPORTAMENTAIS ".

Parecer Consubstanciado da Comissão de Ética no Uso de Animais FMVZ/USP

A Comissão de Ética no Uso de Animais da Faculdade de Medicina Veterinária e Zootecnia da Universidade de São Paulo, no cumprimento das suas atribuições, analisou e APROVOU a Emenda (versão de 11/abril/2017) da proposta acima referenciada.

Resumo apresentado pelo pesquisador: "No projeto original foram previstos experimentos para avaliar o desenvolvimento físico e dos reflexos dos camundongos mutantes tremor (Material e Métodos item 3.3). No entanto, não foi possível realizar esses experimentos em camundongos com fundo genético C57BL/6 devido à baixa taxa de reprodução desse mutante. Como alternativa para obter o número de filhotes necessário para os testes de desenvolvimento, nós propomos realizar os mesmos testes com a mutação original que foi observada na colônia de camundongos Swiss do biotério do VPT. Nesse sentido, será necessário incluir mais dois grupos, ou seja, os camundongos mutantes tremor Swiss e seus respectivos controles Swiss normais, aumentando o número amostral de 62 para 142 animais.".

Comentário da CEUA: "O pesquisador solicitou o aumento do número de animais explicando de forma adequada o porque desta solicitação.".

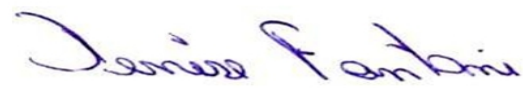

Profa. Dra. Denise Tabacchi Fantoni

Presidente da Comissão de Ética no Uso de Animais

Faculdade de Medicina Veterinária e Zootecnia da Universidade de São Paulo

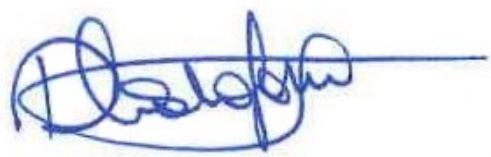

Roseli da Costa Gomes

Secretaria Executiva da Comissão de Ética no Uso de Animais Faculdade de Medicina Veterinária e Zootecnia da Universidade de São Paulo 
Autor: GARCIA-GOMES, Mariana de Souza Aranha

Título: CARACTERIZAÇÃO FENOTÍPICA DO CAMUNDONGO MUTANTE ESPONTÂNEO TREMOR UTILIZANDO UMA BATERIA DE TESTES COMPORTAMENTAIS

Dissertação apresentada ao Programa de PósGraduação em Patologia Experimental e Comparada da Faculdade de Medicina Veterinária e Zootecnia da Universidade de São Paulo para a obtenção do título de Mestre em Ciências

Data:

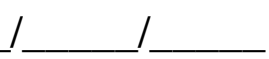

\section{Banca Examinadora}

Prof. Dr.

Instituição: Julgamento:

Prof. Dr.

Instituição: Julgamento:

Prof. Dr. Instituição: Julgamento: 


\section{AGRADECIMENTOS}

Primeiramente aos meus pais e irmãos por todo o amor, carinho, broncas (necessárias) e apoio que me deram - sempre - para que eu fosse alguém cada vez melhor. Obrigada por tudo. Amo vocês.

Aos meus irmãos: sei que sempre poderei contar com vocês.

Aos meus amigos por toda a paciência que sempre tiveram, pelo apoio, pelo amor (do qual eu não seria capaz de sequer questionar) em todos os momentos da minha vida, e pelos nãos que me ajudaram a manter os pés no chão. Vocês me tornam todos os dias alguém melhor, portanto, melhor pra enfrentar isso. Amo vocês.

À minha incrível orientadora Claudia Mori por ter me guiado, ensinado tanto, ajudado a iniciar minha carreira profissional e por tornar isso tão gostoso. Mas principalmente por ser a incrível orientadora e pessoa que é, que tantas vezes soube quando me dizer: "preciso disso para amanhã" ou "vai pra sua casa descansar, amanhã você termina isso". Ter você nesse caminho tornou tudo possível, e sem duvidas, muito mais fácil. Que sejam ainda muitos e muitos anos de trabalho juntas.

A todos os professores do departamento que de forma direta ou indireta ajudaram com o projeto.

Ao meu grupo de trabalho - Jilma, Dennis, Pedro, Sandra e Luciana - sempre tão acessível, disposto e esforçado. Obrigada por ter me permitido confiar meu projeto a vocês. Tive a sorte de poder fazer amigos no trabalho, e a ajuda de vocês foi muito mais do que eu poderia sequer pedir. Obrigada e contem comigo sempre.

Aos colegas de laboratório - Jilma, Dennis, Leonardo, Rafael e Elena - as manhãs de trabalho com sono só foram possíveis por que vocês estavam lá. Obrigada.

As minhas co-orientadoras Martha Bernardi e Silvia Massironi, e ao nosso grupo de pesquisa - Marianna, Jilma, Dennis, Pedro, Ana, Elaine, Sandra, e Tiago - do fundo do meu coração, obrigada por todo o conhecimento passado e discutido. Vocês são incríveis. Muito obrigada. 
Aos colegas pós-graduandos do departamento - especialmente à Thaísa Sandini por toda a ajuda com a coleta de amostras. Muito obrigada.

Ao laboratório de farmacologia do VPT - em especial ao Herculano, à Nicole, e ao Vagner por tudo que sempre ajudaram. Muito obrigada.

Ao laboratório de histopatologia - Luciano e Claudio - por ter ajudado com todas as amostras fixadas, incluídas, cortadas e coradas. Muito obrigada.

À equipe do biotério de Patologia - Luciana, Nelsinho e Mauro. A companhia e a ajuda de vocês foram imprescindíveis. Muito obrigada.

Em especial ao Mauro Mattos, da equipe do biotério, por - em um dia normal de trabalho - ter percebido que naquela caixa em especifico haviam filhotes tremendo, e por ter acreditado na sua desconfiança de que eles deveriam ser estudados. Sem você - literalmente - nada disso teria sido possível. Muitíssimo obrigada.

À CAPES por ter acreditado nesse projeto, ter concedido a bolsa de pesquisa, e tornado isso realidade.

Aos animais que deram a vida pela ciência para que esse estudo se concretizasse, o que cabe a mim é garantir que farei o possível para que não tenha sido em vão.

Esse trabalho é - sem dúvida alguma - de vocês também, a ajuda de cada um foi essencial. 
"Se o cérebro fosse tão simples a ponto de nós podermos entendê-lo; nós seríamos tão simples que não entenderíamos." Lyall Watson 


\section{RESUMO}

GARCIA-GOMES, M. S. A. Caracterização fenotípica do camundongo mutante espontâneo tremor utilizando uma bateria de testes comportamentais. [Phenotypic Caracterization of spontaneous mutant mice tremor using behavioral test batteries.]. 2017; 98 f. Dissertação (Mestrado em Ciências) - Faculdade de Medicina Veterinária e Zootecnia, Universidade de São Paulo, São Paulo, 2017.

A mutação espontânea tremor (tr), autossômica recessiva, foi identificada na colônia de camundongos Swiss no Biotério do Departamento de Patologia da Faculdade de Medicina Veterinária e Zootecnia da Universidade de São Paulo. Os mutantes apresentaram como principais características fenotípicas tremores, ataxia e convulsões tônicas audiogênicas. Por meio de dez retrocruzamentos essa mutação foi transferida para a linhagem congênica C57BL/6 (N10). O mapeamento genético com marcadores microssatélites distribuídos pelo genoma do camundongo indicou que a mutação tr encontra-se no cromossomo 14, na região entre 33,21 e $38,21 \mathrm{cM}$, tendo como possível candidato o gene Egr3 (Early Growth Response 3). O presente estudo teve como objetivo caracterizar o fenótipo comportamental do camundongo mutante tremor. A caracterização do fenótipo dos camundongos mutantes Swiss foi realizada a partir do nascimento até a idade adulta. Os parâmetros do desenvolvimento físico analisados foram: desdobramento das orelhas, erupção dos dentes incisivos, abertura dos olhos, surgimento da pelagem completa, ganho de peso e comprimento dos filhotes e desenvolvimento sexual. No desenvolvimento reflexológico foram analisados: preensão palmar, geotaxia negativa, endireitamento de postura e sobressalto. No $21^{\circ}$ dia de vida foi realizado o teste de campo aberto para analisar a atividade geral dos animais, e no $60^{\circ}$ dia esse teste foi repetido, juntamente com testes para analisar parâmetros comportamentais. Os testes realizados em campo aberto foram ordenados por parâmetro avaliado; 1) atividade geral dos animais e sistema sensorial: frêmito vocal, irritabilidade, reflexo auricular, aperto de cauda, reflexo corneal e resposta ao toque; 2) testes psicomotores: trem posterior, reflexo de endireitamento, tônus corporal e força de agarrar; 3) avaliação do sistema nervoso central: tremores, cauda em pé, micção e defecação. Demais testes realizados analisaram: comportamento em labirinto em cruz elevada, 
coordenação motora em trave elevada, memória espacial no labirinto em $\mathrm{T}$, e respostas comportamentais nos testes de natação forçada e de suspensão pela cauda. Exceto pelo menor peso no desmame, os parâmetros de desenvolvimento analisados não apresentaram diferenças significativas entre os mutantes e controles, - que confirmou a hipótese de que as alterações fenotípicas somente são perceptíveis a partir de 3 semanas de vida. A caracterização comportamental do fenótipo também foi realizada nos mutantes em fundo genético C57BL/6, de ambos os sexos, com 8 semanas de idade. Em relação aos camundongos controle, nos mutantes houve aumento da presença de cauda em pé, da ataxia e do tremor; menor frequência de levantar e de limpeza do corpo (grooming); redução da coordenação motora, indicando evidente prejuízo motor. Também foram observadas respostas negativas à ansiedade e hiperatividade, mas não houve alteração na memória espacial dos mutantes. Os resultados indicaram que o mutante tremor apresentou prejuízos de origem no sistema nervoso central; demostraram também que o fenótipo observado coincide com as alterações descritas na literatura, sugerindo o gene Egr3 como possível candidato para a mutação. A caracterização fenotípica desse animal é importante no entendimento das alterações causadas pela mutação e se essa apresenta potencial como modelo para doenças neurológicas.

Palavras-chave: 1. Mutação espontânea. 2. Deficiência Motora. 3. Ataxia. 4. Gene Egr3. 5. Doenças neurológicas 
ABSTRACT

GARCIA-GOMES, M. S. A. Phenotypic Caracterization of spontaneous mutant mice tremor using behavioral test batteries. [Caracterização fenotípica do camundongo mutante espontâneo tremor utilizando uma bateria de testes comportamentais]. 2017. 98 f. Dissertação (Mestrado em Ciências) - Faculdade de Medicina Veterinária e Zootecnia, Universidade de São Paulo, São Paulo, 2017.

The autosomal recessive spontaneous mutation tremor (tr) was identified in the Swiss mice colony of the laboratory animal facility of the Department of Pathology, from Faculdade de Medicina Veterinária e Zootecnia - Universidade de São Paulo. The mutants presented tremors, ataxia and audiogenic tonic convulsions as the main expressive characteristics. This mutation was moved from Swiss onto C57BL/6- by ten backcrosses (N10). Genetic mapping with microsatellite markers distributed through the mouse genome showed that the mutation is on 14 chromosome, between 33.21 and 38.21 cM, making Egr3 (Early Growth Response 3) a candidate gene. This study aimed to characterize the behavior phenotype of the tremor mice. Phenotypic characterization of the Swiss mutant mice was performed from birth to adulthood. The physical development points analyzed were: unfolding of the ears, eruption of the incisor teeth, opening the eyes, complete fur, weight gain and length, and sexual development. The reflexology development ones were: palmar grip, negative geotaxia, posture straightening and reaction to sound. On the 21-day-old the open field test was performed to analyze the activity of the animals, and on the 60 -day-old this task was repeated along with tests to analyze behavioral parameters. The tests performed in the open field were evaluated by parameters; 1) general activity and sensory system: vocalization, irritability, auricular reflex, tail flick, corneal reflex and response to touch; 2) psychomotor tests: hindquarter fall, surface-righting reflex, body tone and grasping strength; 3) evaluation of the central nervous system: tremors, straub tail, micturition and defecation. Other tests analyzed: behavior in elevated plus maze, motor coordination in balance beam test, spatial memory in $\mathrm{T}$ maze alternation test, and behavioral responses in forced swing and tail suspension tests. Except for the lower weight at weaning, the development parameters analyzed did not show significant differences between the mutants and controls, which 
confirmed the hypothesis that phenotypic changes are only perceptible after 3 weeksold. The behavioral characterization of the phenotype was also performed on 8week-old C57BL/6 mutants of both sexes. In comparison to the control mice, in the mutants there were an increase in the presence of straub tail, ataxia and tremor; less frequent rearing and grooming; less motor coordination, indicating evident motor impairment. Negative responses to anxiety and hyperactivity were also observed, but there was no change in the spatial memory of the mutants. The results indicated that the tremor mutant presented damages in the central nervous system; also showed that the phenotype coincides with the changes described in the literature, suggesting the Egr3 gene as a possible candidate for the mutation. The phenotypic characterization of this animal is important to clarify impairments caused by the genetic mutation, and also identify if this potential model could be useful to study neurological diseases.

Keywords: 1. Spontaneuos mutation. 2. Motor Deficiency. 3. Ataxia. 4. Egr3 Gene.

5. Neurological diseases 


\section{LISTA DE FIGURAS}

\section{CAPÍTULO 1 - Análise o desenvolvimento e caracterização do fenótipo dos camundongos mutantes espontâneos tremor}

Figura 1 - Esquema representativo do delineamento experimental dos testes de desenvolvimento pós-natal, avaliação dos reflexos e testes comportamentais dos camundongos Swiss tremor.

Figura 2 - Esquema de marcação dos filhotes Swiss (controle) e Swiss tremor.......35

Figura 3 - Foto representativa do desdobramento das orelhas em camundongos Swiss: A) filhote com as orelhas ainda dobradas (2PN); B) filhote com as orelhas já desdobradas (3PN) 36

Figura 4 - Foto representativa do surgimento dos dentes incisivos em camundongos Swiss; o filhote já apresenta os incisivos inferiores e os superiores (8PN).

Figura 5 - Foto representativa do surgimento da pelagem completa em camundongos Swiss; o filhote já apresenta pelagem completa (8PN)

Figura 6 - Foto representativa da abertura dos olhos em camundongos Swiss; o filhote já apresenta os olhos abertos (14PN).

Figura 7 - Foto representativa do teste de reflexo de preensão palmar em camundongos Swiss. A) filhote com o reflexo de preensão palmar (3PN); B) filhote já sem o reflexo de preensão palmar (10PN)

Figura 8 - Foto representativa do teste de reflexo endireitamento de postura em camundongos Swiss (3PN). A) no início do teste: filhote em decúbito dorsal; B) filhote com os membros dianteiros já em posição normal; C) filhote voltando à posição normal; D) no fim do teste: em posição normal (3PN). 
Figura 9 - Foto representativa do teste de reflexo de geotaxia negativa em camundongos Swiss. A) filhote no início do teste: com a cabeça direcionada para baixo; B) filhote no fim do teste: com a cabeça direcionada para cima (3PN). .40

Figura 10 - Esquema representativo da sequência dos testes comportamentais utilizados para a fenotipagem dos camundongos Swiss tremor.

Figura 11 - Arena utilizada para a realização do teste de atividade geral em campo aberto

Figura 12 - Foto representativa do aparato utilizado para realização do teste do Labirinto em Cruz Elevada. 45

Figura 13 - Foto representativa do aparato utilizado para teste de Labirinto em Cruz Elevada. A) camundongo C57BL/6 no braço fechado; B) camundongo C57BL/6 no braço aberto

Figura 14 - Foto representativa do aparato utilizado para a realização do teste de coordenação motora em trave elevada, com o camundongo C57BL/6. 46

Figura 15 - Foto representativa do aparato utilizado para realização do teste de memória no Labirinto em $\mathrm{T}$.

Figura 16 - Camundongo C57BL/6 no labirinto em T. A) Camundongo no braço esquerdo do labirinto em T; B) no braço direito; C) na zona inicial.

Figura 17 - Foto representativa da cuba utilizada para realização do teste de natação forçada

Figura 18 - Foto representativa do aparato utilizado para realizar o teste de suspensão pela cauda .50

Figura 19 - Parâmetros analisados dos camundongos Swiss (controle) e Swiss tremor no teste de atividade geral em campo aberto, realizado no dia 21PN. Os 
dados foram apresentados em média e respectivos erros-padrão. Teste t de Student. $A$ - grooming- ${ }^{* * *} p<0,0001 ; B$ - levantar ${ }^{* *} p=0,0015$.

Figura 20 - Parâmetros analisados dos camundongos Swiss (controle) e Swiss tremor de ambos os sexos no teste de atividade geral em campo aberto-60PN. Realizado no dia 60PN. Os dados são apresentados em média e respectivos errospadrão. A - ${ }^{*} p=0,0334 ; B$ - ${ }^{*} p=0,0362 ; C$ e $D$ - ${ }^{* *} p<0,0001$; $E$ - ${ }^{*} p=0,0409$. .56

Figura 21 - Respostas dos camundongos machos Swiss (controle) e Swiss tremor no teste de ansiedade em cruz elevada. São apresentadas as distribuições dos dois grupos. Teste t de Student. A - ${ }^{* \star *} p=0,0006 ; B-{ }^{* *} p=0,0062$. N=8/grupo.

Figura 22 - Respostas dos camundongos machos Swiss (controle) e Swiss tremor no teste de coordenação motora em trave elevada. São apresentadas as distribuições dos dois grupos. ${ }^{* \star *} p=0,0001$ em relação ao grupo controle (teste $U$ de MannWitney). $\mathrm{N}=8 /$ grupo. 59

Figura 23 - Comportamento de camundongos machos Swiss (controle) e Swiss tremor no teste de alternância espontânea em Labirinto em T. Os dados são apresentados em média e respectivos erros-padrão. Teste $U$ de Mann-Witney. $\mathrm{N}=8 /$ grupo. .60

Figura 24 - Comportamento de camundongos machos Swiss (controles) e Swiss tremor no teste de natação forçada. Os dados são apresentados em média e respectivo erro-padrão. Teste $t$ de student. $N=8 /$ grupo. ${ }^{* \star *} p<0,0001$

Figura 25 - Comportamento de camundongos machos Swiss (controle) e Swiss tremor no teste de suspensão pela cauda. Os dados são apresentados em média e respectivo erro-padrão. Teste t de student. $\mathrm{N}=8 /$ grupo. ${ }^{* *} \mathrm{p}<<0,0001$ 61 


\section{CAPÍTULO 2 - Caracterização comportamental do camundongo mutante espontâneo tremor em fundo genético C57BL/6}

Figura 1 - Esquema representativo dos cruzamentos realizados para que a mutação fosse transferida para o fundo genético C57BL/6.

Figura 2 - Atividade geral observada em camundongos C57BL/6 (controle) e C57BL/6 tremor, de ambos os sexos. Resultados observados no teste de atividade geral em campo aberto, (Machos: $n=8 /$ grupo, fêmeas: $n=12 /$ grupo). Os dados são apresentados em média e respectivos erros-padrão. ${ }^{*} p<0,05$ em relação ao grupo controle, teste t de Student. A e B - ${ }^{* \star *} p=0,0003 ;$ C e D - ${ }^{* *} p=0,0033 ; E-{ }^{*} p=0,0243$; $F-{ }^{*} \mathrm{p}=0,0418$

Figura 3 - Resposta ao toque de camundongos C57BL/6 tremor fêmeas. Os dados são apresentados em média e respectivos erros-padrão. Teste $U$ de Mann Witney. $\mathrm{N}=12 /$ grupo. ${ }^{* *} \mathrm{p}=0,0043$.

Figura 4 - Resposta dos camundongos fêmeas C57BL/6 (controle) e C57BL/6 tremor no teste de Labirinto em cruz elevada para ansiedade. EBF- número de entradas no braço fechado. $\mathrm{N}=8 / \mathrm{grupo}$. Os dados são apresentados em média e respectivos desvio-padrão. ${ }^{* * *} p<0,0001$ 76

Figura 5 - Resposta dos camundongos fêmeas C57BL/6 tremor no teste de Labirinto em cruz elevada para ansiedade. Resultados observados no teste de ansiedade em Labirinto em Cruz Elevada. $\mathrm{N}=12 /$ grupo. Os dados são apresentados em média e respectivos desvio-padrão. A - ${ }^{*} p=0,0170$; $-{ }^{* * *} p<0,0001$ .77

Figura 6: Resposta dos camundongos fêmeas C57BL/6 tremor no teste de Labirinto em cruz elevada para ansiedade. \%TBA - porcentagem de tempo nos braços abertos; \%EBA - porcentagem do número de entradas nos braços abertos. $\mathrm{N}=$ 12/grupo. Os dados são apresentados em média e respectivos desvio-padrão. A ${ }^{*} \mathrm{p}=0,0410 ; B-{ }^{* * *} \mathrm{p}<0,0001$ .77

Figura 7 - Resultados dos camundongos machos C57BL/6 (controle) e C57BL/6 tremor no teste no labirinto em cruz elevada para evocação de memória espacial. 
\%EBA - Porcentagem de Entradas nos braços abertos, \%TBA -porcentagem de tempo nos braços abertos. $\mathrm{N}=9$ /grupo. Resultados apresentados em média e respectivos erro-padrão. A - ${ }^{* *} p=0,0014 ; B-{ }^{* *} p=0,0036 ; C \quad-{ }^{* *} p=0,0025 ; D$ ${ }^{*} \mathrm{p}=0,0113$

Figura 8 - Resultados dos camundongos machos C57BL/6 (controle) e C57BL/6 tremor no teste no labirinto em cruz elevada para evocação de memória espacial. EBA - número de entradas nos braços abertos, EBF - número de entradas nos braços fechados. $\mathrm{N}=9$ /grupo. Resultados apresentados em média e respectivos erropadrão. $A-{ }^{* * *} p=0,0003 ; B-{ }^{* *} p=0,0036 ; C-{ }^{* * *} p=0,0008$.

Figura 9 - Resultados dos camundongos machos C57BL/6 (controle) e C57BL/6 tremor no teste no labirinto em cruz elevada para evocação de memória espacial. TBA - tempo nos braços abertos, TBF - tempo nos braços fechados. N=9/grupo. Resultados apresentados em média e respectivos erro-padrão. A - ${ }^{* *} p=0,0025$; B ${ }^{*} \mathrm{p}=0,0113 ; \mathrm{C}-{ }^{* * *} \mathrm{p}=0,0002 ; \mathrm{D}-{ }^{* *} \mathrm{p}=0,0099$ .81

Figura 10 - Resultados dos camundongos fêmeas C57BL/6 (controle) e C57BL/6 tremor no teste no labirinto em cruz elevada para evocação de memória espacial. \%EBA - Porcentagem de Entradas nos braços abertos, \%TBA -porcentagem de tempo nos braços abertos. $\mathrm{N}=12$ /grupo. Resultados apresentados em média e respectivos erro-padrão. A - ${ }^{* *} p=0,0051 ; B-{ }^{*} p=0,0207 ; C \quad-{ }^{* *} p=0,0004 ; D$ ${ }^{* *} \mathrm{p}=0,0063$

Figura 11 - Resultados dos camundongos fêmeas C57BL/6 (controle) e C57BL/6 tremor no teste no labirinto em cruz elevada para evocação de memória espacial. EBA - Entradas nos braços abertos), TBA - tempo nos braços abertos), TBF tempo nos braços fechados. $\mathrm{N}=12$ /grupo. Resultados apresentados em média e respectivos erro-padrão. $A-{ }^{* * *} p=0,0004$; $B-{ }^{* * *} p=0,0006$; $C-{ }^{* *} p=0,0012$; D ${ }^{* *} p=0,0070 ; E-{ }^{* *} p=0,0025 ; F-{ }^{* *} p<0,0001$ .84

Figura 12 - Respostas dos camundongos machos (A) e fêmeas (B) C57BL/6 (controle) e C57BL/6 tremor no teste de coordenação motora em trave elevada. São 
apresentadas as distribuições dos dois grupos. ${ }^{* *} p<0,0001$ (teste $U$ de MannWitney). Machos: $n=8 /$ grupo, fêmeas: $n=12$ /grupo. .85

Figura 13 - camundongo C57BL/6 no teste de coordenação motora em trave elevada. A) camundongo controle C57BL/6 andando na trave; B) camundongo tremor andando na trave. .86

Figura 14 - Comportamento de camundongos C57BL/6 (controle) e C57BL/6 tremor de ambos os sexos no teste de alternância espontânea em Labirinto em T. Os dados são apresentados em média e respectivos erros-padrão. Teste $U$ de MannWitney. .86

Figura 15 - Comportamento de camundongos C57BL/6 (controle) e C57BL/6 tremor de ambos os sexos no teste de natação forçada. Os dados são apresentados em média e respectivos erros-padrão. Teste $T$ de Student. Machos: $n=8 / g r u p o$, fêmeas: $n=12$ grupo. A e $B-{ }^{* * *}<0,0001 ; C-{ }^{* *} p=0,0015$ .88

Figura 16 - Comportamento de camundongos C57BL/6 (controle) e C57BL/6 tremor de ambos os sexos no teste de suspensão pela cauda. Os dados são apresentados em média e respectivos erros-padrão. Teste $T$ de Student. Machos: $n=8 / g r u p o$, fêmeas: $n=12 /$ grupo. A e B ${ }^{* * *} p<0,0001$ 


\section{LISTA DE TABELAS \\ CAPÍTULO 1 - Análise o desenvolvimento e caracterização do fenótipo dos camundongos mutantes espontâneos tremor}

Tabela 1 - Resultados da análise do desenvolvimento físico pós-natal e sexual dos camundongos Swiss (controle) e Swiss tremor. Os dados foram contabilizados pelo dia que o parâmetro foi observado; e estão demonstrados em média e respectivo erro-padrão. .52

Tabela 2 - Resultados obtidos a partir da medição do peso(g) e do comprimento(cm) dos filhotes Swiss (controle) e Swiss tremor. Os dados estão representados em média e respectivo erro-padrão.

Tabela 3 - Resultados da análise dos reflexos em camundongos Swiss (controle) e Swiss tremor. Os dados são contabilizados pelo dia que o parâmetro ocorreu (com exceção do reflexo de preensão palmar; que foi medido o dia que o filhote o perdeu), e estão demonstrados em média e respectivo erro-padrão.

Tabela 4 - Resultados dos parâmetros de atividade geral observados no teste de campo aberto, realizado no dia $21 \mathrm{PN}$ dos camundongos Swiss (controle) e Swiss tremor, representados em média e respectivos erro-padrão. Os parâmetros grooming, levantar, defecação e micção foram contabilizados em número de eventos, e a locomoção foi medida em segundos.

Tabela 5 - Resultados dos parâmetros observados no teste de atividade geral em campo aberto realizado no dia 60PN, dos camundongos Swiss (controle) e Swiss tremor, de ambos os sexos. Os valores são apresentados em média e respectivo erro-padrão. .55

Tabela 6 - Resultados observados a partir da análise de sistema sensorial dos camundongos Swiss (controle) e Swiss tremor, de ambos os sexos, aos 60 dias de idade. Os dados são apresentados em mediana (valor mínimo e máximo). 
Tabela 7 - Respostas dos camundongos machos Swiss (controle) e Swiss tremor no teste de ansiedade no Labirinto em Cruz Elevada. Os valores estão representados em média e respectivos erro-padrão

\section{CAPÍTULO 2 - Caracterização comportamental do camundongo mutante espontâneo tremor em fundo genético C57BL/6}

Tabela 1 -Dados analisados no teste de atividade geral em Campo Aberto. Os dados foram representados em média e respectivos erro-padrão.

Tabela 2 - Sistema sensorial de camundongos C57BL/6 (controle) e C57BL/6 tremor, machos e fêmeas. Os dados são apresentados em mediana (mínimo e máximo)....73

Tabela 3 - Resultados dos parâmetros do sistema nervoso central analisados em campo aberto de camundongos C57BL/6 (controle) e C57BL/6 tremor, machos e fêmeas. Os dados são apresentados em mediana (mínimo e máximo), ou em presente/ausente.

Tabela 4 - Resultados dos camundongos machos obtidos no teste de ansiedade no labirinto em cruz elevada. Dados apresentados em média e respectivos erropadrão .75

Tabela 5 - Resultados dos camundongos fêmeas C57BL/6 (controle) e C57BL/6 tremor no teste de ansiedade em labirinto em cruz elevada. Apresentados em média e respectivos erro-padrão. 76

Tabela 6 - Comparação dos resultados d do teste de memória espacial em labirinto em cruz elevada em camundongos C57BL/6 (controle) e C57BL/6 tremor. Os valores foram apresentados em média e respectivos erro-padrão

Tabela 7: Resultados dos camundongos C57BL/6 (controle) e C57BL/6 tremor fêmeas observados no teste de labirinto em cruz elevada para evocação da memória 
espacial. Os valores foram apresentados em média e respectivos erro-padrão. $\mathrm{N}=12 /$ grupo. . .82

Tabela 8 - Respostas no teste de natação forçada de camundongosC57BL/6 (controle) e C57BL/6 tremor de ambos os sexos. Os dados são apresentados em mediana (mínimo e máximo)

Tabela 9 - Respostas no teste de suspensão pela cauda de camundongos C57BL/6 (controle) e C57BL/6 tremor de ambos os sexos. Os dados são apresentados em mediana (mínimo e máximo) .89 


\section{LISTA DE QUADROS}

CAPÍTULO 1 - Análise o desenvolvimento e caracterização do fenótipo dos camundongos mutantes espontâneos tremor

Quadro 1 - Descrição dos parâmetros utilizados para medir o desenvolvimento físico dos filhotes. .36

Quadro 2 - Parâmetros analisados do sistema sensorial; descrição dos sinais e escores atribuídos.

Quadro 3 - Parâmetros analisados do sistema psicomotor, descrição dos sinais e escores atribuídos. . .44

Quadro 4 - Parâmetros analisados do sistema nervoso central, descrição dos sinais e escores atribuídos.

Quadro 5 - Resultados observados a partir da análise dos parâmetros psicomotores. .57

Quadro 6 - Resultados observados a partir da análise dos parâmetros do sistema nervoso central dos camundongos Swiss (controle) e Swiss tremor de ambos os sexos. .58

\section{CAPÍTULO 2 - Caracterização comportamental do camundongo mutante espontâneo tremor em fundo genético C57BL/6}

Quadro 1 - Resultados dos parâmetros psicomotores analisados em campo aberto, de camundongos C57BL/6 (controle) e C57BL/6 tremor, de ambos os sexos. Os dados são apresentados em mediana (mínimo e máximo), ou em presente ou ausente. 


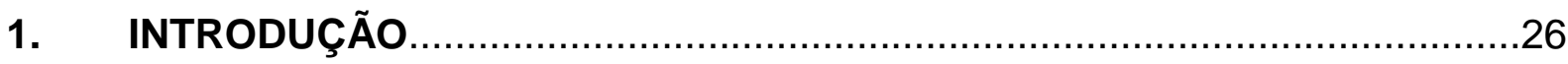

2. OBJETIVOS

3. AVALIAÇÃO DO DESENVOLVIMENTO PÓS-NATAL E CARACTERIZAÇÃO DO FENÓTIPO DOS CAMUNDONGOS MUTANTES ESPONTÂNEOS TREMOR. 30

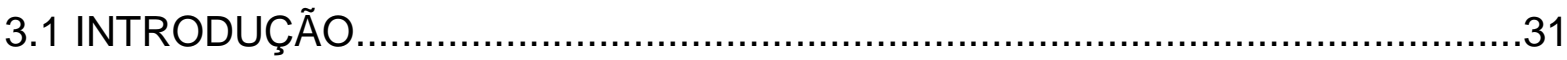

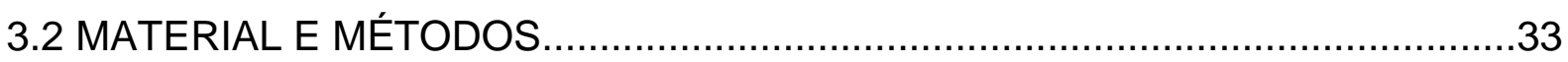

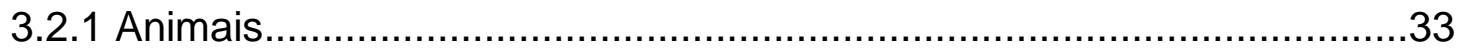

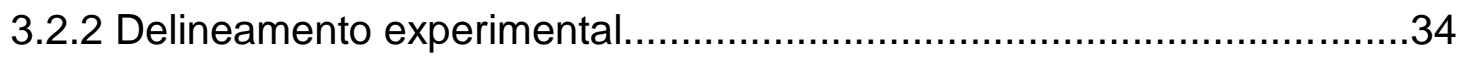

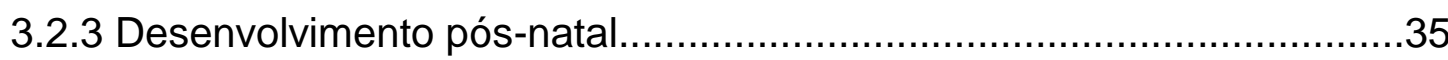

3.2.3.1 Avaliação do desenvolvimento físico........................................35

3.2.3.2 Avaliação dos reflexos durante o desenvolvimento ..................38

3.2.4 Testes Comportamentais .............................................................. 40

3.2.4.1 Atividade geral em Campo Aberto...........................................41

3.2.4.2 Parâmetros Comportamentais................................................42

3.2.4.3 Teste de ansiedade no Labirinto em Cruz Elevada..................44

3.2.4.4 Coordenação motora em Trave elevada...................................46

3.2.4.5 Teste de alternância espontânea em Labirinto em T.................47

3.2.4.6 Teste de Natação Forçada ………….......................................49

3.2.4.7 Teste de Suspensão pela cauda..............................................50

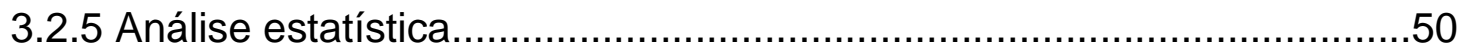

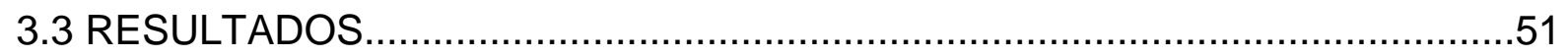

3.3.1 Desenvolvimento pós-natal.................................................................51

3.3.2 Avaliação do desenvolvimento físico ...................................................

3.3.3 Avaliação dos reflexos durante o desenvolvimento...............................52

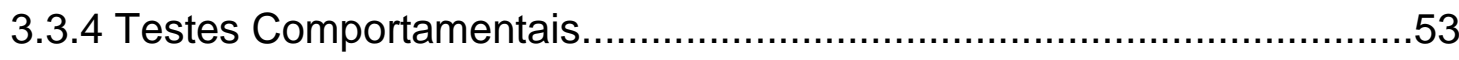

3.3.4.1 Atividade geral em campo aberto...........................................53 
3.3.4.2 Ansiedade no Labirinto em Cruz Elevada..............................58

3.3.4.3 Coordenação Motora em Trave Elevada...............................59

3.3.4.4 Memória em Labirinto em T.............................................60

3.3.4.5 Natação Forçada.............................................................60

3.3.4.6 Suspensão pela cauda............................................61

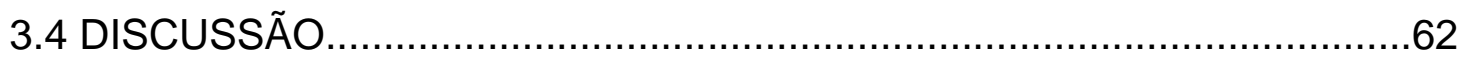

4. CARACTERIZAÇÃO COMPORTAMENTAL DO CAMUNDONGO MUTANTE ESPONTÂNEO TREMOR EM FUNDO GENÉTICO C57BL/6 ...........................65

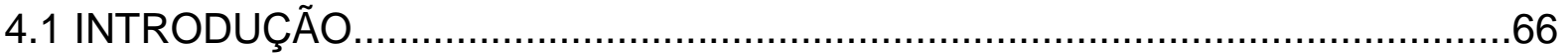

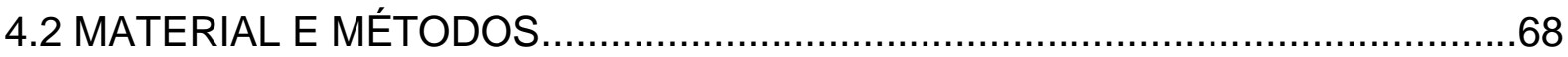

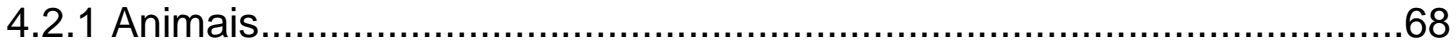

4.2.2 Delineamento experimental...................................................68

4.2.3 Teste do Labirinto em Cruz Elevada para evocação da memória espacial.

4.2.4 Análise estatística...............................................................69

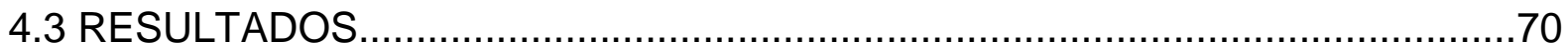

4.3.1 Atividade Geral em Campo Aberto..................................................70

4.3.2 Parâmetros Comportamentais........................................................73

4.3.3 Ansiedade em Cruz Elevada.......................................................75

4.3.4 Evocação de memória espacial no Labirinto em Cruz Elevada.............77

4.3.5 Coordenação Motora em Trave Elevada...........................................85

4.3.6 Memória em Labirinto em T....................................................86

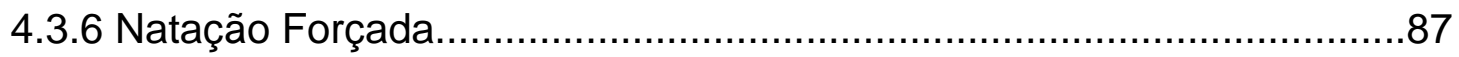

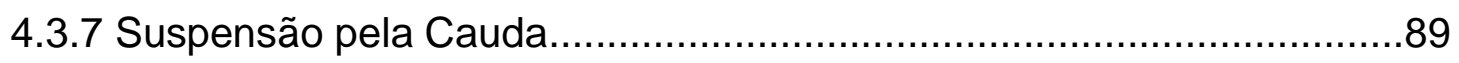

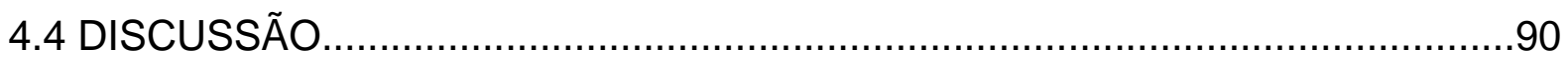

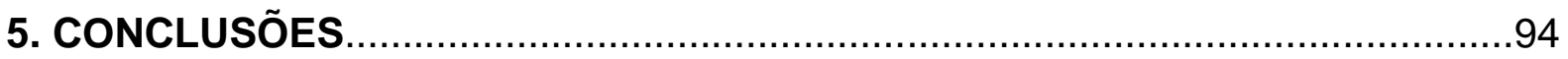

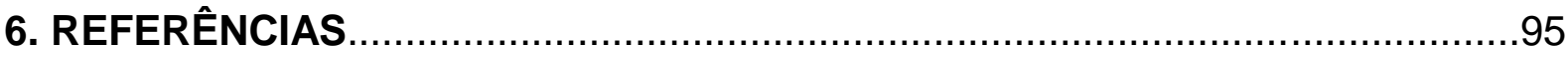




\section{INTRODUÇÃO}

As primeiras linhagens isogênicas de camundongos foram originadas a partir de estudos conduzidos por Miss Abbie Lantthrop, uma professora aposentada que criava camundongos em casa como animais de estimação, e os doava para as Universidades de Harvard e da Pensilvânia, o que, na década de 1900 fez com que esses animais passassem a servir como modelos para as pesquisas em laboratório (MASSIRONI, 2009). Desde então o camundongo é amplamente reconhecido como o modelo animal mais importante na investigação de componentes genéticos e celulares que são relevantes para o entendimento de processos fisiológicos e patológicos em seres humanos. Nesse sentido, um enorme arsenal de ferramentas está disponível para a realização de estudos experimentais em genética de camundongos, incluindo: a grande diversidade de linhagens isogênicas; 0 sequenciamento completo do genoma da linhagem C57BL/6 (além do sequenciamento parcial do genoma de dezenas de outras linhagens isogênicas); disponibilidade de mapas genéticos das variações do genoma (Single Nucleotide Polymorphisms - SNPs) e tecnologia para a manipulação direta e específica do genoma do camundongo (BULT et al., 2013).

O conhecimento do genoma do camundongo em paralelo com 0 conhecimento do genoma humano possibilitou extrapolar os resultados dos testes feitos em camundongos para a espécie humana com maior assertividade o que garante que os modelos animais sejam cada vez mais uteis - e usados com mais consciência - para o estudo das doenças humanas. Em geral, o aparecimento de uma nova mutação em camundongos é um evento raro, ocorrendo em média de $10^{-7}$ a $5 \times 10^{-6}$ em alelos dominantes e $5 \times 10^{-6}$ à $10^{-5}$ em alelos recessivos (GUENÉT, 2004; GUENÉT, 2005). No entanto, as primeiras mutações que foram originalmente estudadas ocorreram espontaneamente como, por exemplo, no caso dos camundongos atímicos nude, descritos pela primeira vez em 1962, em uma colônia de camundongos de laboratório em Glasgow, na Escócia (FLANAGAN, 1966). Devido às características desse modelo animal, o camundongo nude foi responsável por grandes avanços em estudos de imunologia. 
Relatos de literatura descrevem dezenas de mutações, em diferentes regiões do genoma do camundongo, causando, entre muitas outras, alterações neurológicas (NAVE, 1994; SWEET et al. 1996; MENALLED e CHESSELET, 2002; DAPPER e JUSTICE, 2005). Esses modelos constituíram importantes ferramentas para 0 estudo das doenças neurodegenerativas e para o avanço dos seus tratamentos nas últimas décadas. Entretanto, muitas dessas doenças, que acometem o ser humano, apresentam mecanismos pouco conhecidos, e consequentemente ainda não possuem cura. Portanto, modelos animais com alterações neurológicas são de potencial interesse para identificação de genes que podem vir a causar sintomas semelhantes em seres humanos e também para elucidar a patogenia e os mecanismos moleculares envolvidos.

Paralelamente à identificação dos genes envolvidos nessas mutações e das funções bioquímicas de seus produtos, que fornecem uma parte das informações sobre o fenótipo observado, o objetivo final da descrição de um modelo mutante é a determinação das funções do gene no contexto de todo o organismo. Desta forma, a análise comportamental auxilia na compreensão dos fenômenos que envolvem alterações no sistema nervoso central e periférico. Inicialmente, realiza-se o exame físico desses animais, observando-se aspectos comportamentais simples que são indicativos de saúde geral, tais como: peso corporal, temperatura corpórea, aparência da pele e pelos, atividade na gaiola, desempenho reprodutivo, agressão, construção de ninhos, etc. Observam-se também os reflexos neurológicos procurando identificar quaisquer deficiências graves que poderão impedir a realização de outros testes comportamentais. Posteriormente, as tarefas motoras e sensoriais servem para avaliar as habilidades físicas do mutante estudado (CRAWLEY, 2003; CRAWLEY, 2008).

Na colônia de camundongos Swiss, do Biotério do Departamento de Patologia da Faculdade de Medicina Veterinária e Zootecnia da Universidade de São Paulo, foi identificada uma mutação espontânea, autossômica recessiva, cujo primeiro fenótipo observado foi a presença de tremores que eram evidentes quando o animal se locomovia na gaiola, o que levou a denominar esse mutante de tremor. Muitos dos modelos mutantes espontâneos estudados, principalmente roedores, apresentam o tremor como característica fenotípica proeminente, por exemplo: em camundongos: trembler, shiverer, jimpy, ou em ratos: zitter. Alguns dos achados patológicos comuns a esses mutantes incluem desmielinização ou degeneração espongiforme 
central e periférica do sistema nervoso; já nos modelos de camundongos; vibrator e wobbler são lesões comuns a degeneração espinocerebelar e do sistema motor, respectivamente, outros modelos como os ratos shaker também apresentam degeneração das células de Purkinje (HIDETO MIWA, 2007)

Howng et al. (2010) descreveram o fenótipo do camundongos mutante hmcns, resultante de uma mutação recessiva que surgiu espontaneamente no fundo genético $\mathrm{C} 3 \mathrm{H} / \mathrm{HeJ}$. Esses mutantes foram caracterizados pelo tremor e a ocorrência de convulsões tônicas, começando no dia 14 pós-natal, devido à intensa hipomielinização no SNC. Geralmente, a maioria dos mutantes morre por volta de 25 dias de idade. $\mathrm{O}$ mapeamento genético desses camundongos revelou que o gene hmcns é um novo alelo do gene Zfp191, localizado no cromossomo 18, que desempenha um papel importante no processo de mielinização pelos oligodendrócitos. O mutante hmons apresenta características fenotípicas semelhantes ao tremor; no entanto, as alterações neurológicas parecem ser mais brandas em nossos mutantes, que sobrevivem por mais de 12 meses.

Considerando a importância de se estudar as mutações espontâneas ocorridas em roedores de laboratório, os objetivos do presente estudo foram: avaliar o desenvolvimento pós-natal e caracterizar o fenótipo da mutação tremor em camundongos Swiss. Ainda com o propósito de realizar o mapeamento genético, a mutação tremor foi transferida por cruzamentos para camundongos de fundo genético C57BL/6, os quais também foram fenotipicamente caracterizados por estudos comportamentais. 


\section{OBJETIVOS}

Os objetivos desse trabalho foram caracterizar o fenótipo dos camundongos mutantes tremor visando o estabelecimento de um possível modelo animal para estudos de doenças neurológicas em seres humanos e outras espécies animais, e para tanto:

- Avaliar o desenvolvimento físico pós-natal em camundongos Swiss tremor em comparação aos animais controle.

- Avaliar o desenvolvimento pós-natal dos reflexos em camundongos Swiss tremor em comparação aos animais controle.

- Avaliar por observação direta parâmetros da atividade geral, sensoriais, psicomotores e ligados ao sistema nervoso central e autônomo dos camundongos Swiss e C57BL/6 tremor e seus respectivos controles no campo aberto;

- Avaliar a coordenação motora dos camundongos Swiss e C57BL/6 tremor e seus respectivos controles no teste da trave elevada;

- Avaliar a memória espacial dos camundongos Swiss e C57BL/6 seus respectivos controles pelo teste de labirinto em $\mathrm{T}$;

- Avaliar a ansiedade dos camundongos Swiss e C57BL/6 tremor e seus respectivos controles, bem como, a memória espacial dos mutantes em fundo genético C57BL/6, no teste de labirinto em cruz elevada;

- Avaliar o comportamento dos camundongos Swiss e 2C57BL/6 tremor e seus respectivos controles a partir dos testes de nado forçado e suspensão pela cauda. 


\section{CAPÍTULO 1}

AVALIAÇÃO DO DESENVOLVIMENTO PÓS-NATAL E CARACTERIZAÇÃO DO FENÓTIPO DOS CAMUNDONGOS MUTANTES ESPONTÂNEOS TREMOR 


\subsection{INTRODUÇÃO}

A mutação espontânea tremor foi primeiramente identificada na colônia de camundongos heterogênicos Swiss, mantida no Biotério do Departamento de Patologia da Faculdade de Medicina Veterinária e Zootecnia da Universidade de São Paulo, por observação direta dos filhotes no momento do desmame, ou seja, com três semanas de vida. Foi observado que alguns filhotes de uma determinada ninhada apresentavam tremores, ataxia e convulsões tônicas de origem audiogênica. Esses filhotes foram desmamados e selecionados para estudos posteriores. Devido as suas características fenotípicas esses animais foram denominados tremor (tr). Observações iniciais demonstraram que ambos os sexos eram férteis, entretanto, as fêmeas apresentavam fertilidade inferior quando comparadas aos camundongos Swiss normais. O resultado dos cruzamentos entre animais mutantes, heterozigotos e selvagens permitiram caracterizar a mutação como de herança autossômica recessiva.

Segundo Ettinger \& Feldman (2004), tremores consistem em oscilações rítmicas involuntárias do corpo. São caracterizados por contrações musculares de alta frequência e relaxamento. Alguns autores classificam os tremores entre de ação e de repouso. Acredita-se que os tremores de repouso são causados pela perda de neurônios estriados nos núcleos da base, em humanos esses tremores são vistos na doença de Parkinson. Podem ocorrer tremores intencionais quando o movimento é direcionado para um objetivo, em geral são vistos em animais com doença cerebelar que acomete a verme ou as zonas cerebelares laterais. Esses animais também podem ter outros sintomas cerebelares como ataxia, dismetria e nistagmo. Os tremores de ação são vistos quando os músculos de um membro se contraem e podem aumentar quando a precisão do movimento é necessária. Em cães e gatos são descritas síndromes congênitas de tremor, ainda não muito bem esclarecidas e tais distúrbios só afetam o sistema nervoso central e podem ser hipomielinizantes ou desmielinizantes. Algumas doenças humanas de origem neurológica como, por exemplo, a esclerose múltipla ou o mal de Parkinson, também causam tremores que estão ligados à desmielinização dos neurônios cerebrais (RUBERT et. al., 2007; NEVES, et. al., 2007.). 
Convulsão é a manifestação clínica de uma descarga excessiva de neurônios cérebro-corticais hiperexcitáveis (ETTINGER \& FELDMAN, 2004). Nas células, há um desequilíbrio entre mecanismos excitatórios e inibitórios que favorecem o início súbito da excitação. O ácido gama-aminobutírico (GABA) e o glutamato são os principais neurotransmissores inibitórios e excitatórios. A inibição defeituosa de receptores GABA pode ter função essencial na patogênese de epilepsias, além de ativação defeituosa dos neurônios pelo GABA e tamponamento intracelular defeituoso do cálcio (LORENZ, 2006). Estudos realizados em modelos animais como, por exemplo, o rato WAR (Wistar Audiogenic Rat) e o hamster GASH:Sal, sugerem que os genes da família EGR (early growth response) possuem papel importante nos mecanismos envolvidos com as crises convulsivas audiogênicas (LÓPEZ-LÓPEZ et al., 2015). Estudos recentes demonstraram que os camundongos knockout das subunidades $\alpha 1$ dos receptores GABAa apresentavam tremor com características semelhantes às que estão presentes no tremor essencial em humanos: como tremor postural e cinético, e incoordenação motora. Esses camundongos apresentavam respostas deficientes (ou inexistentes) ao estímulo gabaérgico sináptico ou exógeno nas células de Purkinje no cerebelo, mesmo sem alterações morfológicas no SNC (HIDETO-MIWA, 2007).

Dezenas de mutações, em diferentes regiões do genoma do camundongo, causando alterações neurológicas já foram descritas (NAVE, 1994; SWEET et al. 1996; MENALLED \& CHESSELET, 2002; DAPPER \& JUSTICE, 2005). Esses modelos constituíram importantes ferramentas para o estudo das doenças neurodegenerativas e para o avanço dos tratamentos nas últimas décadas. Entretanto, muitas doenças neurodegenerativas que acometem o ser humano apresentam mecanismos pouco conhecidos e, muitas delas ainda não possuem tratamento. Nesse sentido, modelos animais com alterações neurológicas são de potencial interesse para identificar genes que podem causar sintomas semelhantes em seres humanos e também, para elucidar a patogenia e mecanismos moleculares envolvidos nessas doenças.

Assim sendo, esse trabalho teve como objetivo realizar os primeiros estudos de desenvolvimento físico pós-natal e dos reflexos além de caracterizar o comportamento dos mutantes tremor em diferentes idades uma vez que essas informações poderão contribuir para a identificação do gene mutado. Desta forma, após a caracterização fenotípica e molecular da mutação será possível correlacionar 
as alterações observadas com doenças humanas ou de outras espécies animais que se assemelhem, tornando o mutante tremor um possível modelo para estudos relacionados.

\subsection{MATERIAL E MÉTODOS}

\subsubsection{Animais}

Os camundongos (Mus musculus) utilizados nos experimentos foram provenientes do Biotério do Departamento de Patologia da Faculdade de Medicina Veterinária e Zootecnia da Universidade de São Paulo (FMVZ-USP), de padrão sanitário convencional monitorizado. Durante o experimento os animais foram mantidos em gaiolas de polipropileno medindo $30 \times 20 \times 13 \mathrm{~cm}$ com cama de granulado de sabugo de milho (Zea mays) autoclavado, trocada semanalmente. A sala dos animais era mantida com temperatura de $22 \pm 2{ }^{\circ} \mathrm{C}$ e umidade relativa do ar de $55 \pm 10 \%$. A iluminação artificial, controlada por "timer", com ciclo de 12 horas de claro e 12 horas de escuro. Ração comercial para camundongos (Nuvilab-CR1, Quimtia S.A., PR, Brasil) e água filtrada e autoclavada foram oferecidas ad libitum durante todo o experimento. As condições de alojamento e manejo dos animais estavam de acordo com as normas éticas internacionais, em especial àquelas do NRC (National Research Council, 2011).

Os procedimentos experimentais foram submetidos e aprovados pela Comissão de Ética no Uso de Animais da FVMZ/USP e receberam número de protocolo 4124150116, aprovado no dia 23 de Março de 2016. 


\subsubsection{Delineamento experimental}

O projeto foi dividido em duas partes: estudo do desenvolvimento pós-natal dos filhotes, e, posteriormente com os mesmos animais foi realizada a bateria de testes comportamentais, para a avaliação desses animais na idade adulta (conforme esquema mostrado na figura 1).

Figura 1 - Esquema representativo do delineamento experimental dos testes de desenvolvimento pósnatal, avaliação dos reflexos e testes comportamentais dos camundongos Swiss tremor.

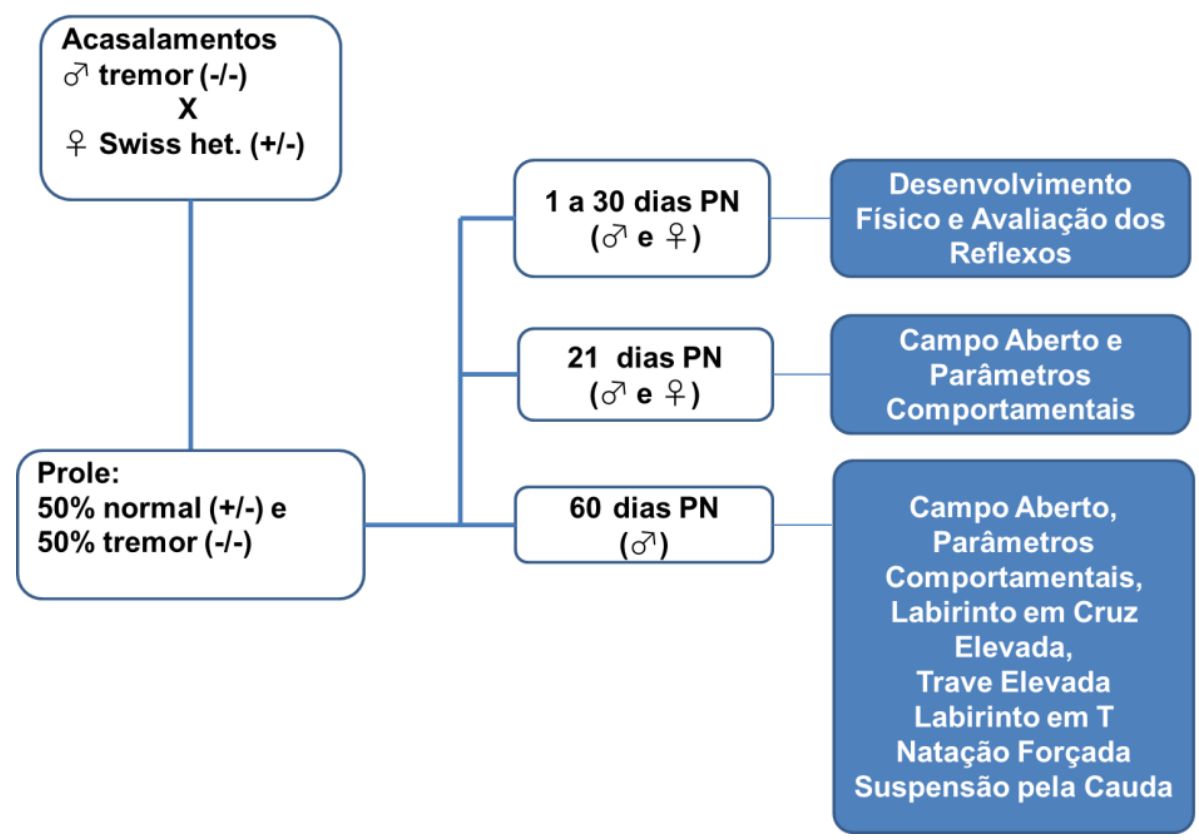

Fonte: (GARCIA-GOMES, 2017).

Para os testes de desenvolvimento 10 fêmeas Swiss heterozigotas para a mutação tremor (portadoras da mutação $[+/-]$ ) foram acasaladas com 5 camundongos machos homozigotos (afetados pela mutação [-/-]) para que a prole fosse composta de camundongos portadores e afetados em iguais proporções. Cada macho foi alojado em uma gaiola com duas fêmeas, aleatoriamente.

No dia 1 pós-natal (PN) as ninhadas foram padronizadas com 8 indivíduos, para que não houvesse competição entre os filhotes, que interferiria no desenvolvimento dos mesmos. Essa medida de padronizar as ninhadas foi adotada a partir da $2^{\mathrm{a}}$ ninhada - havíamos optado por não padronizá-las, já que não seria possível determinar quais eram os animais afetados e quais não, no entanto a 
primeira ninhada apresentou crescimento não homogêneo e mortalidade dos filhotes, o que nos fez optar pela padronização - gerando então a análise de apenas 9 das 10 ninhadas.

Após a padronização das ninhadas os filhotes foram marcados com tinta nanquim injetada por via subcutânea nos membros com as cores: vermelho ou verde (conforme esquema mostrado na figura 2).

Figura 2 - Esquema de marcação dos filhotes Swiss (controle) e Swiss tremor.

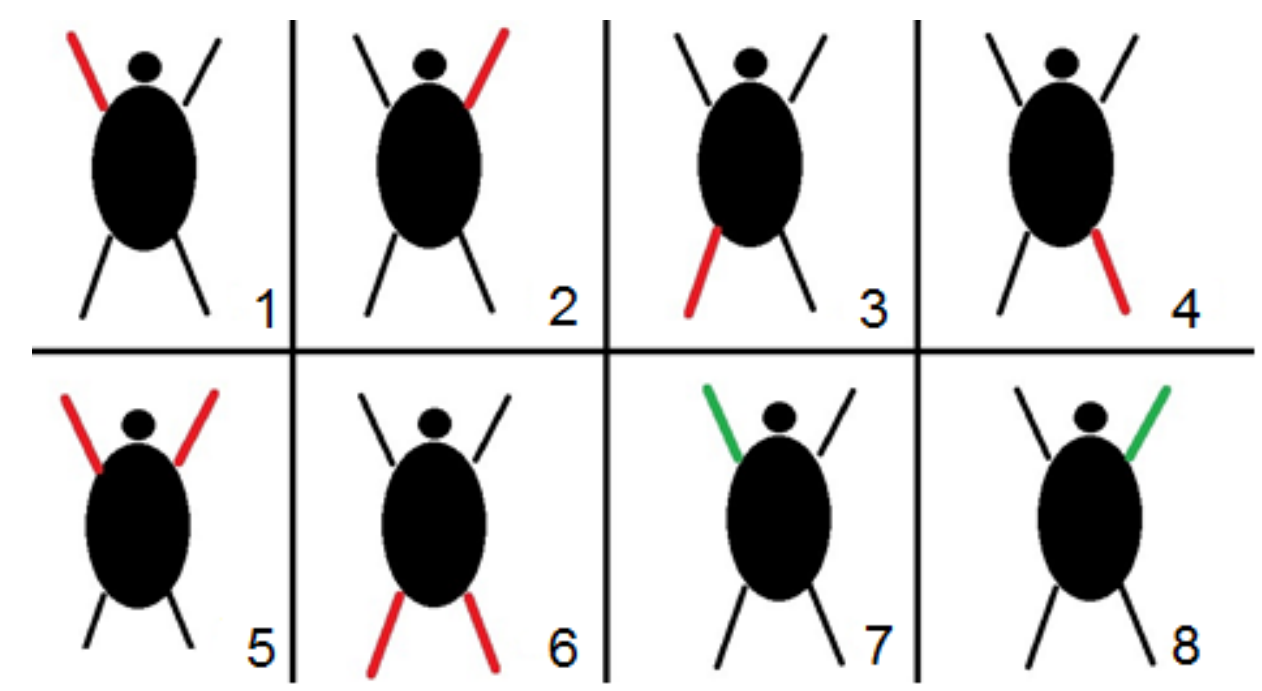

Fonte: (GARCIA-GOMES, 2016).

\subsubsection{Desenvolvimento pós-natal}

\subsubsection{Avaliação do desenvolvimento físico}

$\mathrm{Na}$ avaliação do desenvolvimento físico dos animais foram utilizados 68 filhotes (34 mutantes e 34 controles) e observados os dias de ocorrência dos seguintes parâmetros: desdobramento das orelhas, abertura dos olhos e erupção dos dentes incisivos inferiores e superiores, conforme pode ser observado no quadro 1 e nas figuras 3 a 6 .

As medições dos filhotes; comprimento - do focinho até a base da cauda (em centímetros) e peso (em gramas) foram realizadas nos dias 6, 13, e 21 PN. Ao final 
do experimento os pesos e os comprimentos dos animais mutantes e dos controles foram comparados.

Quadro 1 - Descrição dos parâmetros utilizados para medir o desenvolvimento físico dos filhotes.

\begin{tabular}{|l|l|l|}
\hline Parâmetro & $\begin{array}{l}\text { Período de } \\
\text { observação }\end{array}$ & Descrição \\
\hline Desdobramento da orelha & 3 a 6 PN & dia que as orelhas haviam se desdobrado \\
\hline Erupção dos dentes & 6 a 11 PN & $\begin{array}{l}\text { observação feita abrindo a boca dos filhotes com } \\
\text { ajuda de um clipes de papel - dia que o filhote } \\
\text { apresentou o a erupção dos incisivos inferiores e } \\
\text { superiores }\end{array}$ \\
\hline Surgimento de pelos & 7 a 9 PN & $\begin{array}{l}\text { dia que o filhote apresentava a troca completa da } \\
\text { pelugem por pelo. }\end{array}$ \\
\hline Abertura dos olhos & 11 a 16 PN & $\begin{array}{l}\text { dia que o filhote apresentou a primeira fresta da } \\
\text { abertura de pelo menos um dos olhos }\end{array}$ \\
\hline
\end{tabular}

Fonte: (adaptada de www.jax.org, 2017).

Figura 3 - Foto representativa do desdobramento das orelhas em camundongos Swiss: A) filhote com as orelhas ainda dobradas (2PN); B) filhote com as orelhas já desdobradas (3PN).

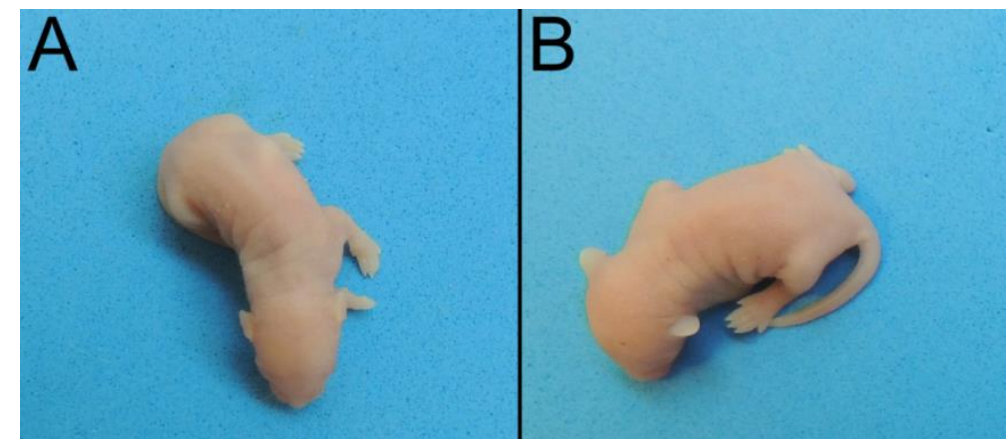

Fonte: (GARCIA-GOMES, 2017).

Figura 4 - Foto representativa do surgimento dos dentes incisivos em camundongos Swiss; o filhote já apresenta os incisivos inferiores e os superiores (8PN).

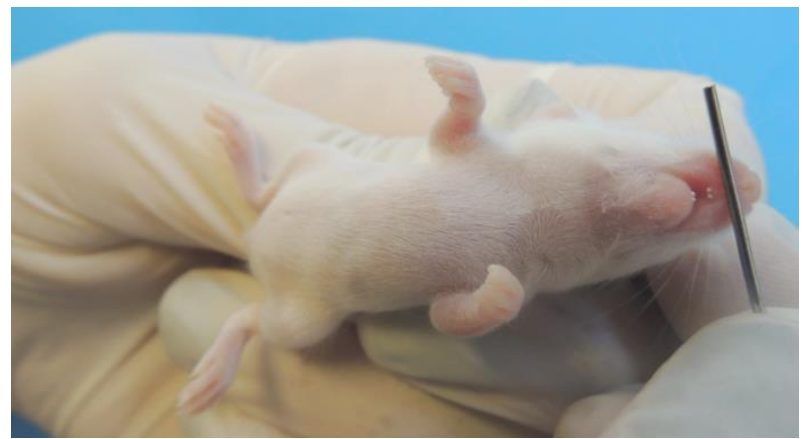

Fonte: (GARCIA-GOMES, 2017). 
Figura 5 - Foto representativa do surgimento da pelagem completa em camundongos Swiss; o filhote já apresenta pelagem completa. (8PN)

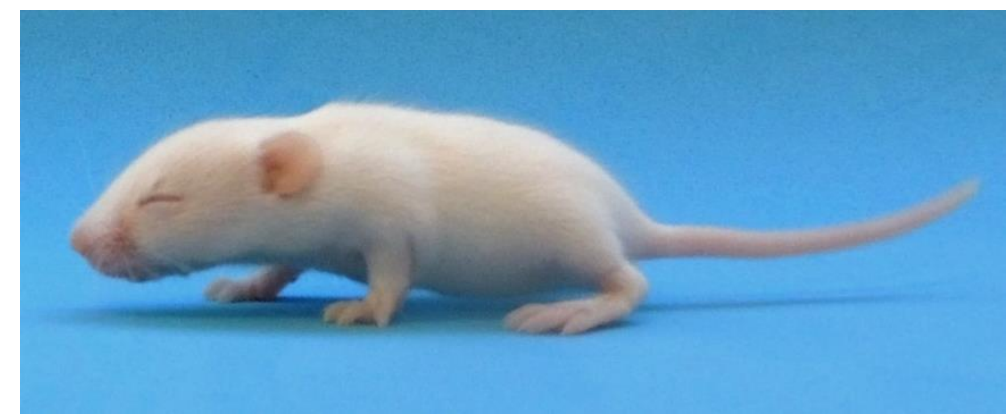

Fonte: (GARCIA-GOMES, 2017).

Figura 6 - Foto representativa da abertura dos olhos em camundongos Swiss; o filhote já apresenta os olhos abertos (14PN).

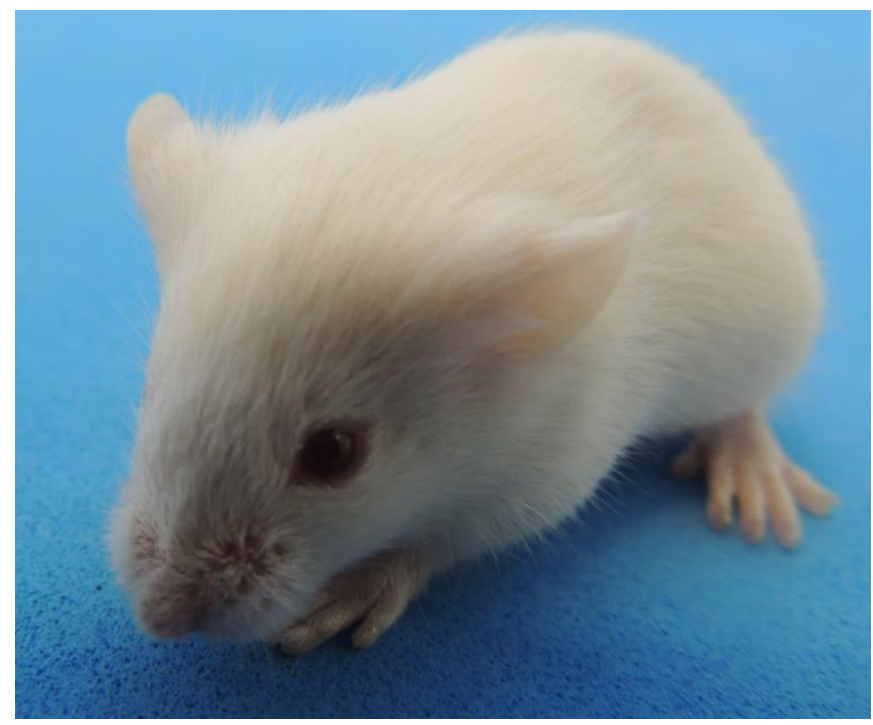

Fonte: (GARCIA-GOMES, 2017).

Para a avaliação do desenvolvimento sexual foram utilizados 40 camundongos (10 mutantes e 10 controles de ambos os sexos) e observando-se o dia de descida dos testículos e da abertura vaginal, conforme segue: a) descida de testículo: foi observado o dia em que os dois testículos desceram para a bolsa escrotal, no período entre $18^{\circ}$ e $23^{\circ}$ dia de vida dos filhotes machos, ou até que fosse observada a descida dos testículos (O'SHAUGHNESSY \& SHEFFIELD, 1991); b) abertura vaginal: foi registrado o dia da ocorrência da fresta vaginal. Esta observação foi realizada a partir do $30^{\circ}$ dia de vida dos filhotes fêmeas. 


\subsubsection{Avaliação dos reflexos durante o desenvolvimento}

Para a avaliação dos reflexos foram utilizados 68 filhotes, sendo 34 mutantes e 34 controles.

\section{Reflexo de preensão palmar}

Os filhotes eram contidos na mão do experimentador, e tinham uma das patas dianteiras tocada com a ponta de um clipes de papel para avaliação do reflexo de preensão palmar. $O$ critério para ocorrência do reflexo era o animal fechar a pata ao contato com o clipes (figura 7A). Este teste foi realizado do dia 1 ao dia $10 \mathrm{PN}$, ou até que os filhotes o perdessem. $O$ esperado era que o reflexo desaparecesse com o passar dos dias (figura 7B), ao contrário dos demais reflexos.

Figura 7 - Foto representativa do teste de reflexo de preensão palmar em camundongos Swiss. A) filhote com o reflexo de preensão palmar (3PN); B) filhote já sem o reflexo de preensão palmar $(10 \mathrm{PN})$.

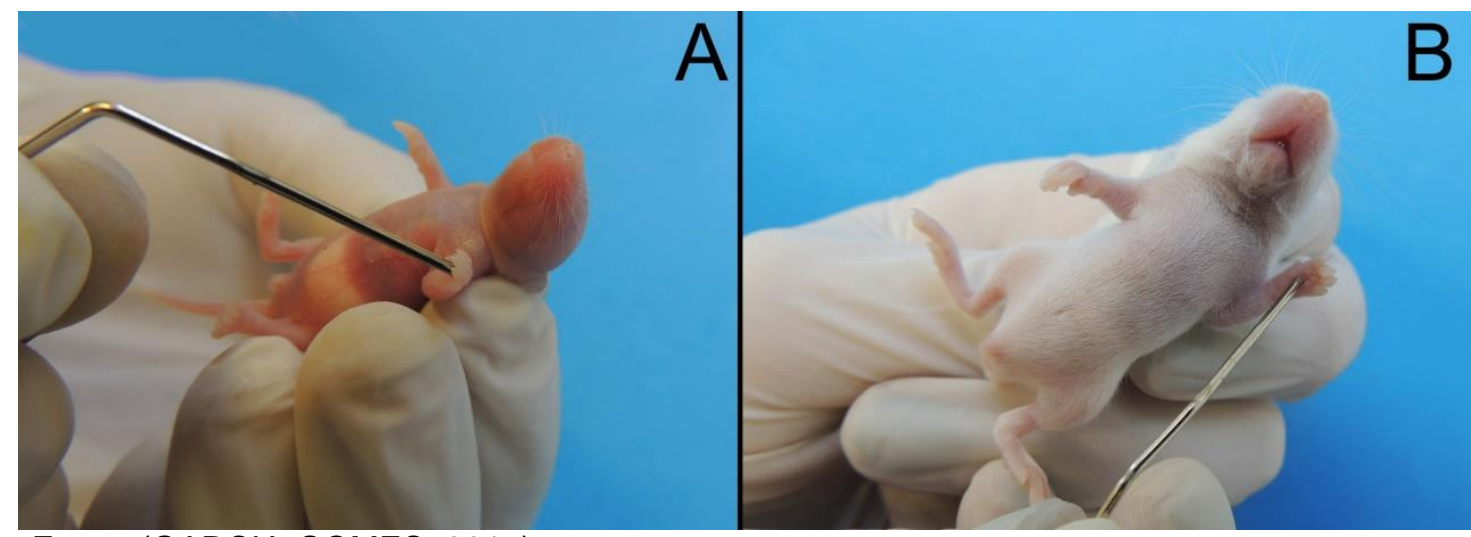

Fonte: (GARCIA-GOMES, 2017).

\section{Reflexo de endireitamento de postura}

Cada filhote era colocado em decúbito dorsal (figura 8A), e deveria voltar à posição normal do corpo, com os quatro membros espalmados na superfície (figuras 
8B, $8 \mathrm{C}$ e 8D). O período de latência máximo para este teste era de 30 segundos. Caso o filhote não conseguisse, era registrado que ele ainda não apresentava esse reflexo. O teste foi realizado a partir do $5^{\circ}$ dia $\mathrm{PN}$, até que todos apresentassem o reflexo.

Figura 8 - Foto representativa do teste de reflexo endireitamento de postura em camundongos Swiss (3PN). A) no início do teste: filhote em decúbito dorsal; B) filhote com os membros dianteiros já em posição normal; C) filhote voltando à posição normal; D) no fim do teste: em posição normal (3PN).

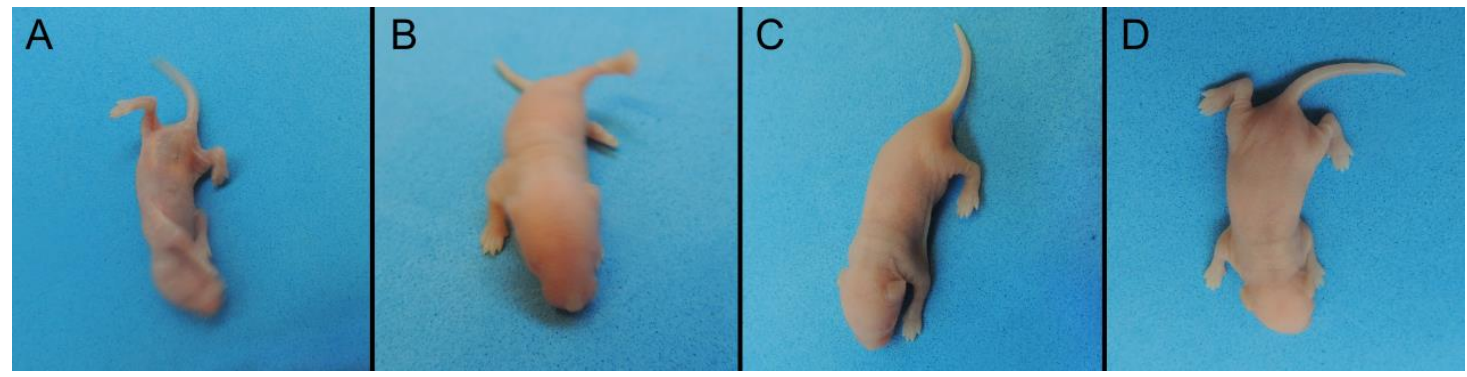

Fonte: (GARCIA-GOMES, 2017).

\section{Reflexo de geotaxia negativa}

O animal foi colocado em uma rampa de aproximadamente $45^{\circ}$ de inclinação, a $5 \mathrm{~cm}$ borda inferior dessa superfície, com a cabeça direcionada para baixo (figura 9A). O tempo que o animal demorou para virar na posição oposta, ou seja; com a cabeça para cima (figura 9B), foi medido. Os animais que não apresentaram o reflexo na primeira tentativa foram testados mais duas vezes. A ocorrência na primeira, segunda ou terceira tentativas foi registrada. Este teste foi realizado a partir do dia 4PN, a cada dois dias, até que o filhote apresentasse o reflexo. A latência máxima medida foi de 1 minuto. 
Figura 9 - Foto representativa do teste de reflexo de geotaxia negativa em camundongos Swiss. A) filhote no início do teste: com a cabeça direcionada para baixo; B) filhote no fim do teste com a cabeça direcionada para cima (3PN).

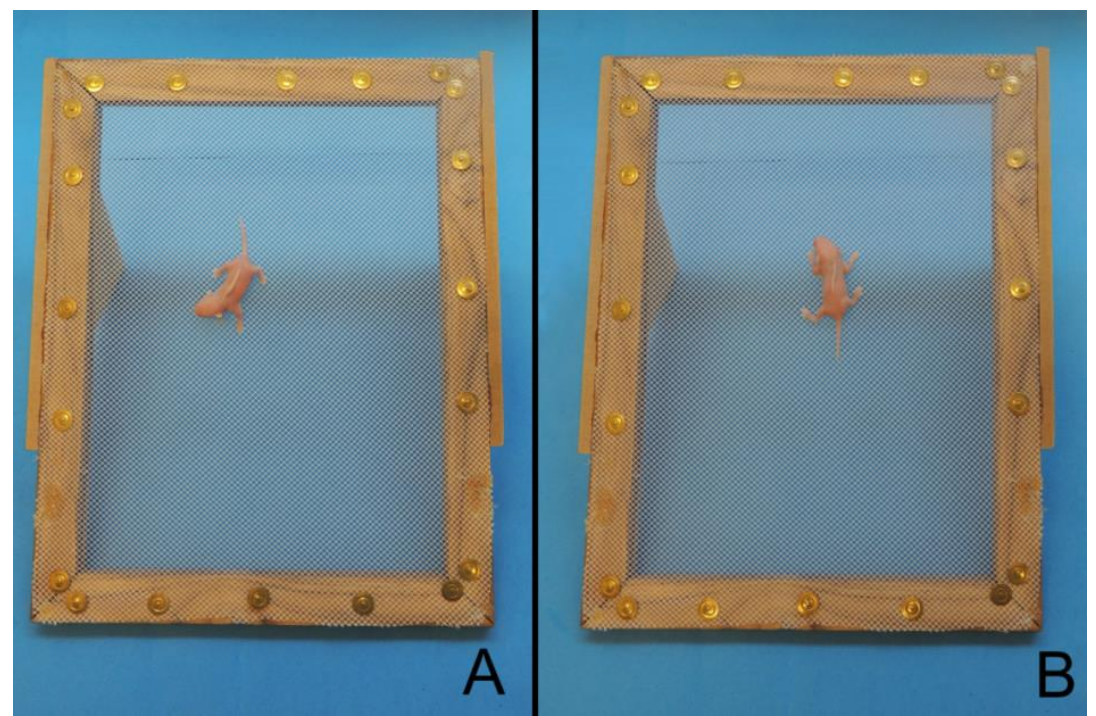

Fonte: (GARCIA-GOMES, 2017).

\section{Reflexo de sobressalto}

Os filhotes foram colocados na bancada e expostos a um estalido curto e seco - movimento de um molho de chaves ou estalar dos dedos, segundo Alder e Zbinden, (1977). Foi observado quando o animal apresentava movimentação logo após o ruído, que representou que o conduto auditivo estava aberto e que o animal tinha audição. Foi registrado o dia em que o animal apresentou pela primeira vez este reflexo. O teste foi realizado do $11^{\circ}$ ao $14^{\circ}$ dia $\mathrm{PN}$, ou até que os animais apresentassem o reflexo (RICCl et. al., 2014).

\subsubsection{Testes Comportamentais}

Para avaliação do fenótipo foi utilizada uma bateria de testes comportamentais (figura 10) que objetivavam a observação do estado geral de saúde, dos reflexos neurológicos, das habilidades sensoriais e da função motora dos animais que foram utilizados. Os testes foram realizados ao longo de 6 semanas, 
com o cuidado de que fosse realizado apenas um teste por semana e pelo menos 6 dias de intervalo entre um teste e outro para que os animais não sofressem influencia do teste anterior. Também tomou-se o cuidado para que os testes fossem realizados em ordem crescente de estresse pelo mesmo motivo, uma vez que testes estressantes aumentariam o nível de estresse dos animais e gerariam resultados questionáveis. Durante todos os testes, entre uma sessão e outra os labirintos foram limpos com solução de álcool a $5 \%$ para que o cheiro do animal anterior não influenciasse no próximo, nem o cheiro do álcool gerasse incômodo aos animais.

Figura 10 - Esquema representativo da sequência dos testes comportamentais utilizados para a fenotipagem dos camundongos Swiss tremor.

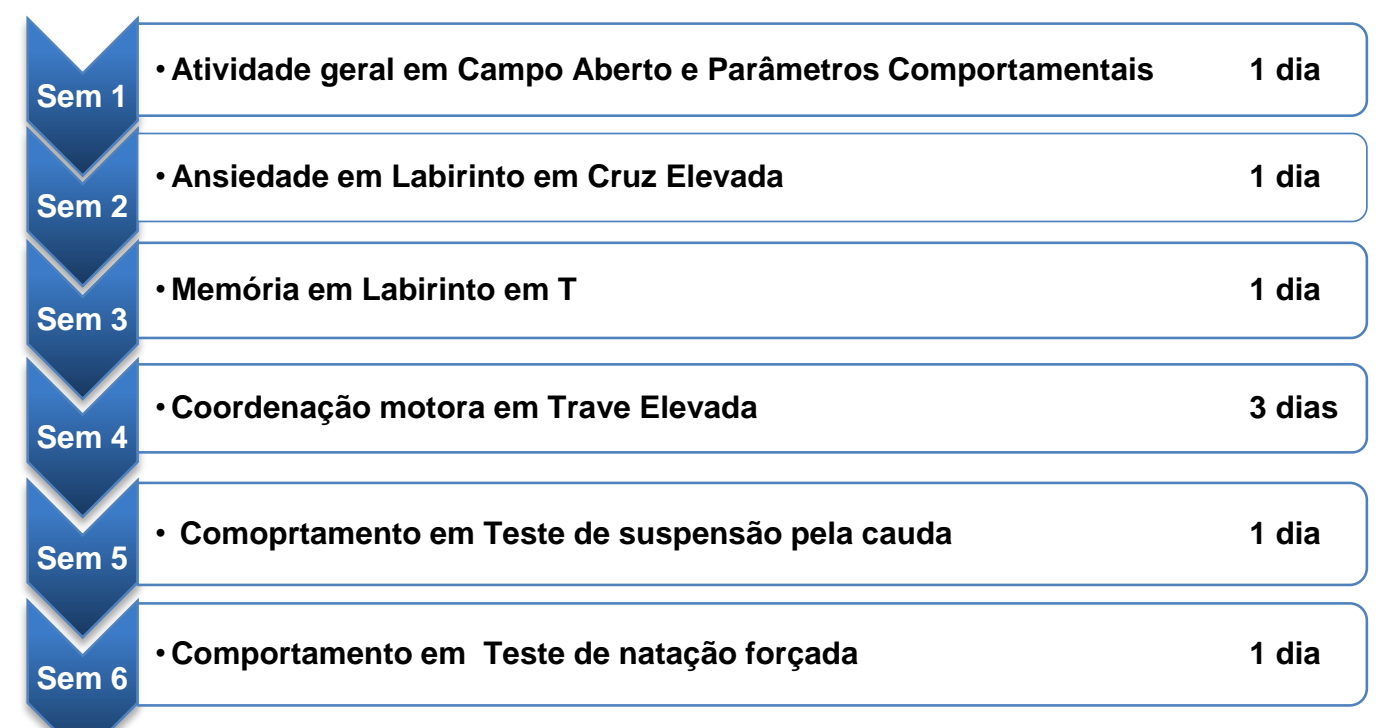

Fonte: (GARCIA-GOMES, 2017).

\subsubsection{Atividade geral em Campo Aberto}

O teste no labirinto de campo aberto teve o objetivo caracterizar de forma quantitativa e qualitativa os parâmetros exploratórios e motores em um ambiente novo (TATEM et. al., 2014), e foi realizado nos camundongos em duas idades, no dia do desmame (dia 21PN) e nos animais adultos (60PN). No dia 21PN foram utilizados 26 mutantes tremor e 26 controles, sem diferenciação por sexo. No dia 60PN os grupos de animais foram separados por sexo, para evitar possíveis influências hormonais após a puberdade, sendo testados 10 machos e 10 fêmeas 
mutantes e seus respectivos controles. Os testes foram realizados em campo aberto redondo de cor preta com $39 \mathrm{~cm}$ de diâmetro; que ficava a aproximadamente $50 \mathrm{~cm}$ do chão (figura 11).

Os parâmetros anotados foram: tempo de exploração (tempo em segundos que o animal explora a arena do campo aberto, seja com exploração horizontal ou vertical - quando o animal se levanta), frequência de levantar (número de vezes que o animal ficou apoiado sobre os membros posteriores com o corpo ereto, apoiandose ou não nas paredes do campo) e grooming - (número de vezes que o animal limpou o corpo com os membros dianteiros ou mostrou qualquer outra atividade voltada a si mesmo; como coçar-se), número de bolos fecais e de poças de micção.

Figura 11 - Arena utilizada para a realização do teste de atividade geral em campo aberto.

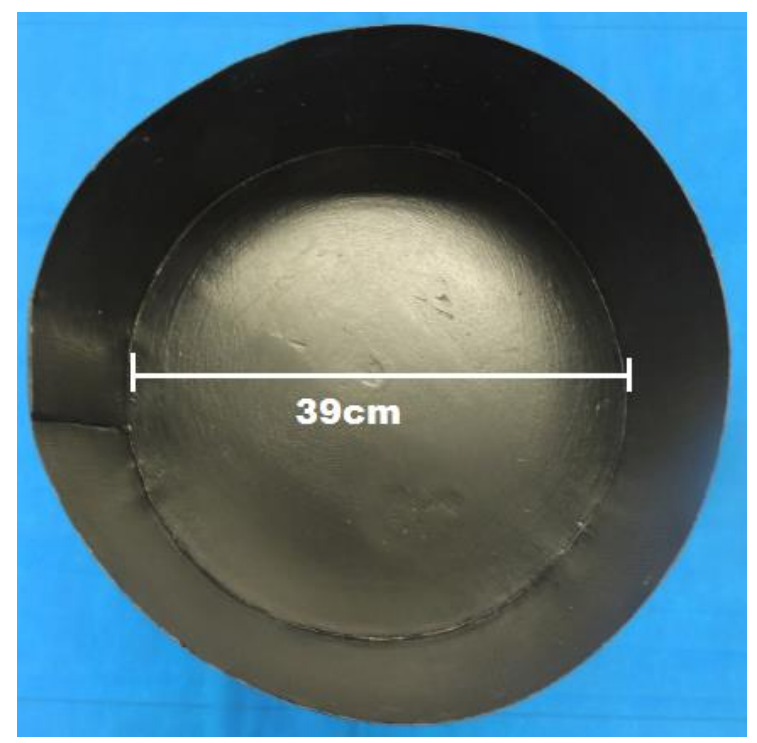

Fonte: (GARCIA-GOMES, 2017).

\subsubsection{Parâmetros Comportamentais}

A análise dos parâmetros comportamentais serviu para complementar o teste de atividade geral em campo aberto e avaliar possíveis alterações espontâneas na motilidade, psicomotoras, sensoriais e do sistema nervoso central apresentadas pelos mutantes (ESTORK et al.,2014). Neste teste cada camundongo foi observado diretamente por uma sessão de 5 minutos em que os seguintes parâmetros foram 
medidos como presente ou ausente, ou por escores quando necessário, e anotados: 1) sistema sensorial, quantificando: frêmito vocal, irritabilidade, reflexo auricular, aperto de cauda, reflexo corneal e resposta ao toque, como mostra o quadro 2 ; 3 ) testes psicomotores: trem posterior, reflexo de endireitamento, tônus corporal e força de agarrar, conforme quadro 3; 4) avaliação do sistema nervoso central e autônomo: tremores, cauda em pé, ataxia micção e defecação, como mostra o quadro 4. As sessões foram filmadas com uma câmera localizada a $2 \mathrm{~m}$ do chão para que fossem analisadas posteriormente com ajuda do software OpenFLD.Ink (disponível em http://blog.sbnec.org.br/2010/07/softwares-gratuitos-para-analise-do-labirinto-emcruz-elevado-e-campo-aberto/, no dia 21 de Out. de 2016).

Quadro 2 - Parâmetros analisados do sistema sensorial; descrição dos sinais observados e escores atribuídos.

\begin{tabular}{|c|c|c|}
\hline Parâmetro & Descrição dos sinais & Escores atribuídos \\
\hline Frêmito Vocal & $\begin{array}{l}\text { Emissão de som sem nenhuma } \\
\text { estimulação ou toque. }\end{array}$ & $\begin{array}{l}\text { ausente } \\
\text { presente }\end{array}$ \\
\hline Irritabilidade & $\begin{array}{l}\text { Se o animal apresenta reação } \\
\text { ao ser tocado ou assoprado. }\end{array}$ & $\begin{array}{l}\text { Ausente } \\
\text { Presente }\end{array}$ \\
\hline $\begin{array}{l}\text { Reflexo } \\
\text { Auricular }\end{array}$ & $\begin{array}{l}\text { Posição da orelha, quanto mais } \\
\text { próxima à cabeça menor é o } \\
\text { reflexo, logo após estalar os } \\
\text { dedos várias vezes seguidas. }\end{array}$ & $\begin{array}{l}0 \text { - orelha totalmente em pé (ausente) } \\
1 \text { - orelha um pouco mais em pé (base) } \\
2 \text { - orelha metade em pé } \\
3 \text { - orelha colada ligeiramente à cabeça } \\
4 \text { - orelha colada à cabeca }\end{array}$ \\
\hline $\begin{array}{l}\text { Aperto de } \\
\text { Cauda }\end{array}$ & $\begin{array}{l}\text { Reação do animal logo após ter } \\
\text { a região próxima á ponta da } \\
\text { cauda pressionada com } \\
\text { bastante intensidade. }\end{array}$ & $\begin{array}{l}0 \text { - sem reação (ausente) } \\
1 \text { - move-se ligeiramente } \\
2 \text { - move-se mais rápido } \\
3 \text { - move-se e pula (base) } \\
4 \text { - move-se, pula e corre }\end{array}$ \\
\hline $\begin{array}{l}\text { Reflexo } \\
\text { Corneal }\end{array}$ & $\begin{array}{l}\text { Reação do animal ao ver uma } \\
\text { pinça se aproximando, } \\
\text { lentamente dos seus olhos, mas } \\
\text { sem encostar. }\end{array}$ & $\begin{array}{l}0 \text { - olhos abertos (ausente) } \\
1 \text { - quase não se move } \\
2 \text { - se move um pouco } \\
3 \text { - fecha-os pela metade na aproximação da } \\
\text { pinça } \\
4 \text { - fecha-os totalmente na aproximação da pinça } \\
\text { (base) }\end{array}$ \\
\hline $\begin{array}{l}\text { Resposta ao } \\
\text { Toque }\end{array}$ & $\begin{array}{l}\text { Resposta do animal ao ser } \\
\text { tocado com uma pinça por um } \\
\text { intervalo de tempo mais } \\
\text { prolongado ( } 15 \text { segundos). }\end{array}$ & $\begin{array}{l}0 \text { - não se move } \\
1 \text { - apresenta pouco movimento } \\
2 \text { - animal dá um passo } \\
3 \text { - anda com dificuldade } \\
4 \text { - anda com agilidade (base) }\end{array}$ \\
\hline
\end{tabular}

Fonte: (adaptada de BRITO, 1994). 
Quadro 3 - Parâmetros analisados do sistema psicomotor, descrição dos sinais observados e escores atribuídos.

\begin{tabular}{|c|c|c|}
\hline Parâmetro & Descrição dos Sinais & Escores atribuídos \\
\hline Trem Posterior & $\begin{array}{l}\text { Postura normal ou com } \\
\text { o trem posterior caído } \\
\text { (intensidade, modo de } \\
\text { andar). }\end{array}$ & $\begin{array}{l}0 \text { - ausente (base) } \\
1 \text { - queda do trem posterior pouco visível } \\
2 \text { - queda do trem posterior visível. Animal anda com } \\
\text { dificuldade } \\
3 \text { - trem posterior visivelmente caído Animal anda com } \\
\text { dificuldade } \\
4 \text { - trem totalmente caído. Animal andando com } \\
\text { dificuldade, arrastando o trem posterior }\end{array}$ \\
\hline $\begin{array}{l}\text { Reflexo de } \\
\text { Endireitamento }\end{array}$ & $\begin{array}{l}\text { Reação do animal ao } \\
\text { ser colocado de dorso } \\
\text { para baixo e a latência } \\
\text { que ele volta à sua } \\
\text { posição normal. }\end{array}$ & $\begin{array}{l}0 \text { - não se move (ausente) } \\
1 \text { - volta-se lentamente com dificuldade } \\
2 \text { - volta-se lentamente } \\
\text { 3- volta-se mais rápido } \\
4 \text { - volta-se imediatamente (base) }\end{array}$ \\
\hline Tônus Corporal & $\begin{array}{l}\text { Presença ou não e grau } \\
\text { do mesmo }\end{array}$ & $\begin{array}{l}\text { ausente } \\
\text { presente (base) }\end{array}$ \\
\hline $\begin{array}{l}\text { Força de } \\
\text { agarrar }\end{array}$ & $\begin{array}{l}\text { Intensidade com que o } \\
\text { animal se segura em } \\
\text { uma grade quando } \\
\text { colocado sobre ela. }\end{array}$ & $\begin{array}{l}0 \text { - não se agarra à grade (ausente) } \\
1 \text { - segura inicialmente mas solta a grade } \\
2 \text { - segura a grade por um tempo um pouco prolongado, } \\
\text { mas a solta } \\
\text { 3- segura firmemente a grade, mas a solta } \\
4 \text { - não solta (base) }\end{array}$ \\
\hline
\end{tabular}

Fonte: (adaptada de BRITO, 1994).

Quadro 4 - Parâmetros analisados do sistema nervoso central, descrição dos sinais observados e escores atribuídos.

\begin{tabular}{|l|l|l|}
\hline Parâmetro & Descrição dos sinais & Escore atribuído \\
\hline Tremores & Presentes ou não e qual a intensidade & ausente presente \\
\hline Cauda em pé & Cauda normal ou ereta quando o animal se move & ausente presente \\
\hline Ataxia & Movimentos descoordenados & ausente presente \\
\hline
\end{tabular}

Fonte: (adaptada de BRITO, 1994).

\subsubsection{Teste de ansiedade no Labirinto em Cruz Elevada}

No teste de ansiedade no Labirinto em Cruz Elevada e nos demais testes comportamentais foram utilizados somente os camundongos machos, sendo 8 mutantes e 8 controles por grupo. Este teste foi validado em 1990 por Lister (1990) para avaliação da ansiedade em camundongos frente a um espaço aberto (KOMADA et al., 2008). O aparato consiste em uma cruz com dois dos braços abertos e dois fechados, cada um com $30 \mathrm{~cm}$ de comprimento e $16 \mathrm{~cm}$ de altura nos 
fechados, apoiado sobre uma base de aproximadamente $50 \mathrm{~cm}$ de altura (figura 12). No primeiro dia os animais foram colocados no centro da cruz elevada, com a cabeça voltada para o braço fechado, e analisados por cinco minutos. Nesse tempo foram medidas: a quantidade de entradas nos braços fechados (EBF - figura 13A) e nos braços abertos (EBA - figura 13B), e quanto tempo que o animal passava em cada um deles (TBF - nos braços fechados; TBA - nos braços abertos). Uma câmera foi instalada a $2 \mathrm{~m}$ do chão para que os testes fossem filmados para posterior análise com ajuda do software PlusMz (disponível em http://blog.sbnec.org.br/2010/07/softwares-gratuitos-para-analise-do-labirinto-emcruz-elevado-e-campo-aberto/, no dia 21 de Out. de 2016).

Figura 12 - Foto representativa do aparato utilizado para realização do teste do Labirinto em Cruz Elevada.

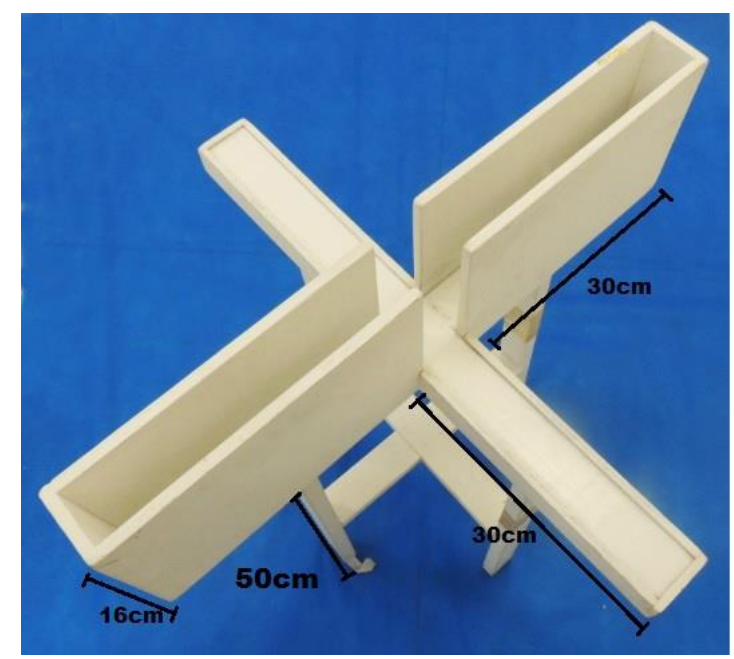

Fonte: (GARCIA-GOMES, 2017).

Figura 13 - Labirinto em Cruz Elevada. A) camundongo C57BL/6 no braço fechado; B) camundongo no braço aberto.
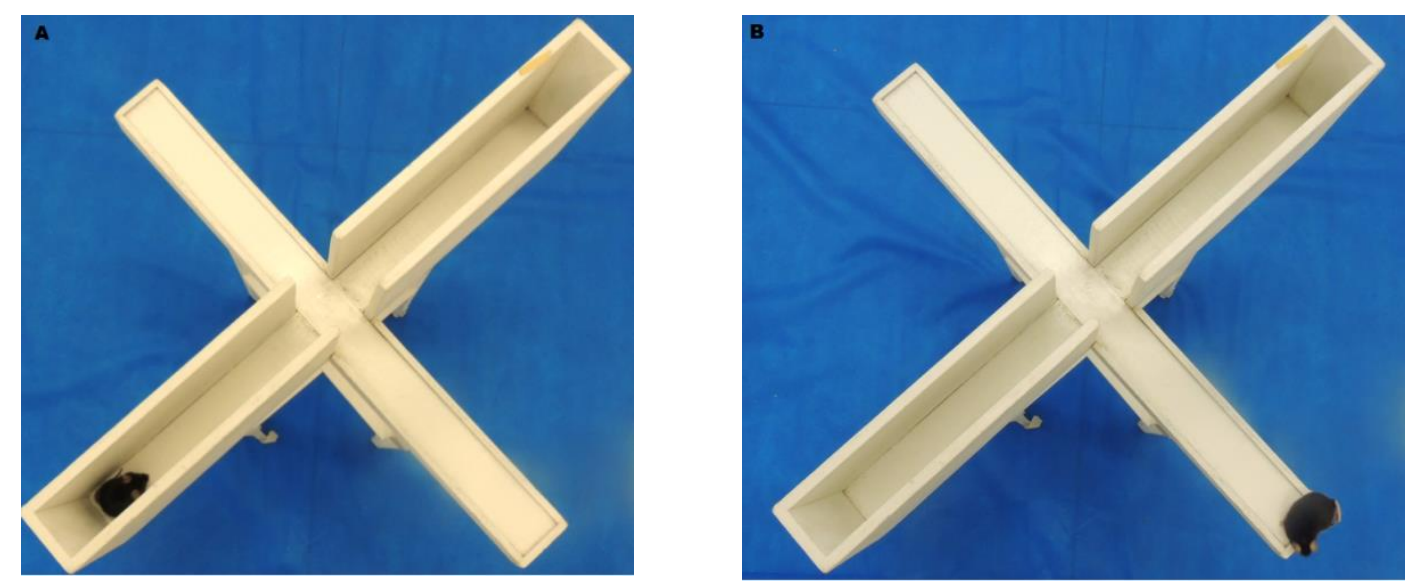

Fonte: (GARCIA-GOMES, 2017). 


\subsubsection{Teste de coordenação motora em Trave elevada}

Este teste foi empregado para avaliar possíveis alterações na coordenação motora de camundongos mutantes (LUONG et al., 2011). O aparato consiste em uma trave de $1,5 \mathrm{~cm}$ de largura, e $150 \mathrm{~cm}$ de comprimento, posicionada a $20 \mathrm{~cm}$ do chão, apoiada nas extremidades sobre duas bases, (figura 14). Na extremidade final da barra foi posicionado um abrigo com o sabugo de milho triturado da caixa moradia do animal que passaria pela trave, na extremidade inicial foi colocada uma luz - que servia como estimulo aversivo, para estimular que os camundongos atravessassem a trave. No primeiro dia foi realizado um treino, que consistia em 3 tentativas de atravessar a barra, com duração de 5 minutos cada. $O$ camundongo era colocado no início, e o tempo cronometrado, ao fim de cada tentativa (fim do tempo ou quando o animal atravessava a trave) o camundongo era recolocado no ponto inicial. $O$ treino foi repetido no dia seguinte, e no terceiro dia foi realizado 0 teste; composto de uma única tentativa de atravessar a trave - que durava 3 minutos - que era avaliada por um escore, sendo: 0 - quando o camundongo não andava, 4 - quando o camundongo andava se arrastando, ou apresentava qualquer dificuldade para andar e 7 - quando ele andava sem dificuldades. Os camundongos que desceram pela plataforma durante o treino foram avaliados com escore 0 , mas não participaram do teste. Quando um animal caía da trave ele era recolocado no ponto de onde caiu; animais que caíram mais de três vezes foram retirados daquele treino ou teste. $O$ dia de teste foi filmado por uma câmera posicionada a $1,5 \mathrm{~m}$ de altura, a $2 \mathrm{~m}$ da trave para posterior análise.

Figura 14 - Foto representativa do aparato utilizado para a realização do teste de coordenação motora em trave elevada, com o camundongo C57BL/6.

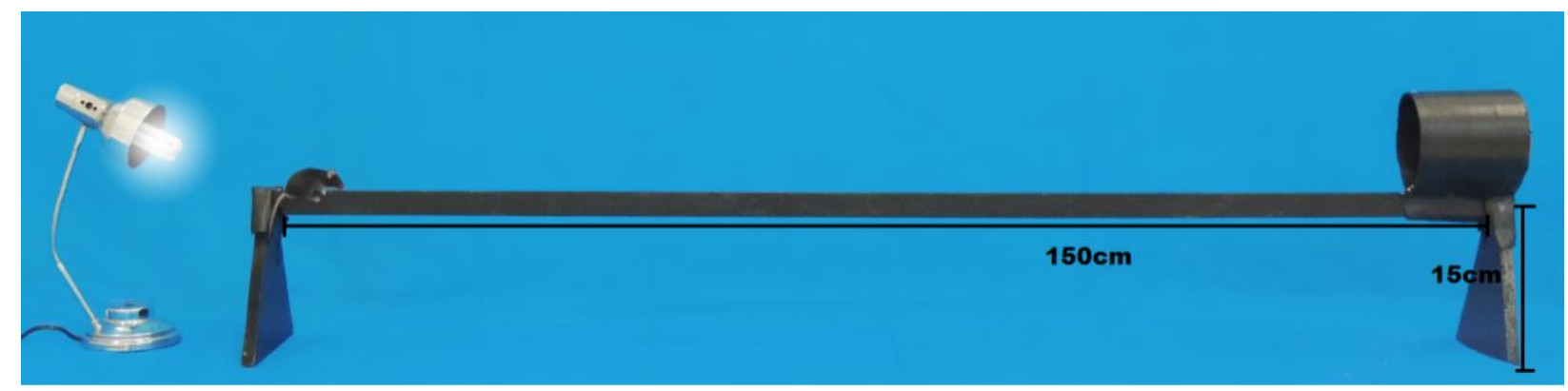

Fonte: (GARCIA-GOMES, 2017). 


\subsubsection{Teste de alternância espontânea em Labirinto em T}

Este teste foi empregado para avaliar possíveis alterações apresentadas pelos camundongos mutantes em aprendizado operacional (DEACON \& RAWLINS, 2006). O teste foi realizado em um labirinto em $T$ para camundongos - esse labirinto fica apoiado sob uma base de $50 \mathrm{~cm}$ de altura, cada braço tem $25 \mathrm{~cm}$ de comprimento e $14 \mathrm{~cm}$ de altura. No inicio de cada braço existe uma comporta que isola aquela área, e pode ser aberta ou fechada durante o teste (figura 15). $O$ camundongo era colocado na zona inicial do $\mathrm{T}$, com a comporta fechada, e lá permanecia por 10 segundos (figura 16C). Após esse tempo o camundongo podia escolher livremente em qual braço entrar, permanecendo no labirinto por 30 segundos. Se depois desse tempo nenhum braço tivesse sido escolhido o camundongo era recolocado na base do T novamente por mais 10 segundos. Caso o camundongo escolhesse um braço, a comporta era fechada impossibilitando que ele voltasse para a base. Após decorrido o tempo de 30 segundos no braço ele era novamente colocado na base por mais 10 segundos para que o procedimento fosse repetido até que 0 animal tivesse entrado 5 vezes nos braços(figuras $16 \mathrm{~A}$ e B). $\mathrm{O}$ camundongo ganhava um ponto cada vez que entrava em um braço diferente daquele da sessão anterior - sendo que 4 era o escore máximo, caso os braços não fossem repetidos, e 0, o mínimo, caso o animal entrasse todas as vezes no mesmo braço. 
Figura 15 - Foto representativa do aparato utilizado para realização do teste de memória no Labirinto em T.

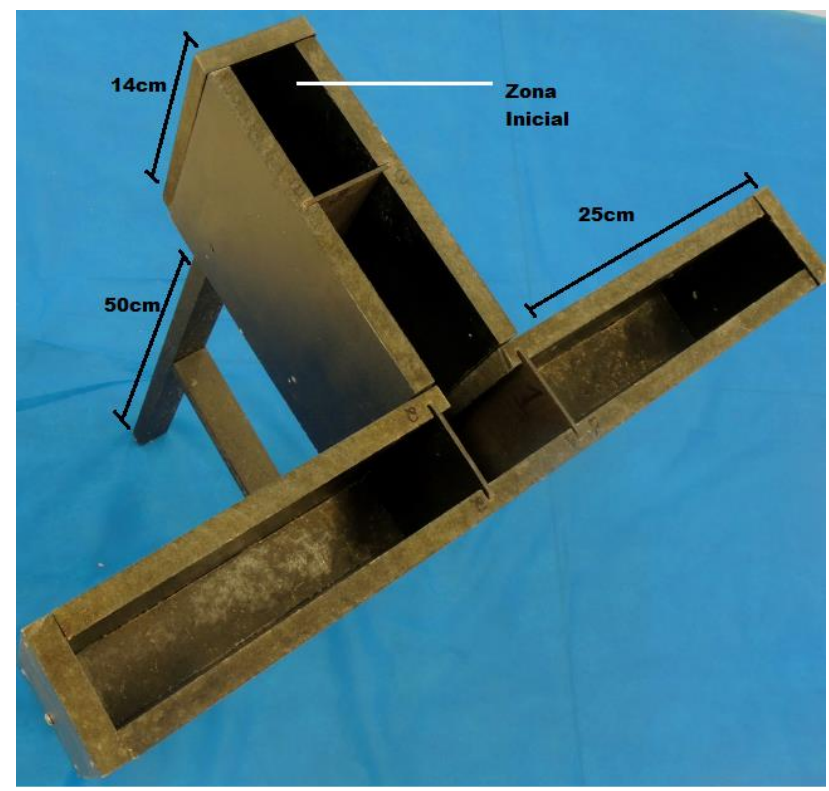

Fonte: (GARCIA-GOMES, 2017).

Figura 16 - camundongo C57BL/6 no Labirinto em T. A) Camundongo no braço esquerdo do labirinto em T; B) no braço direito; C) na zona inicial.

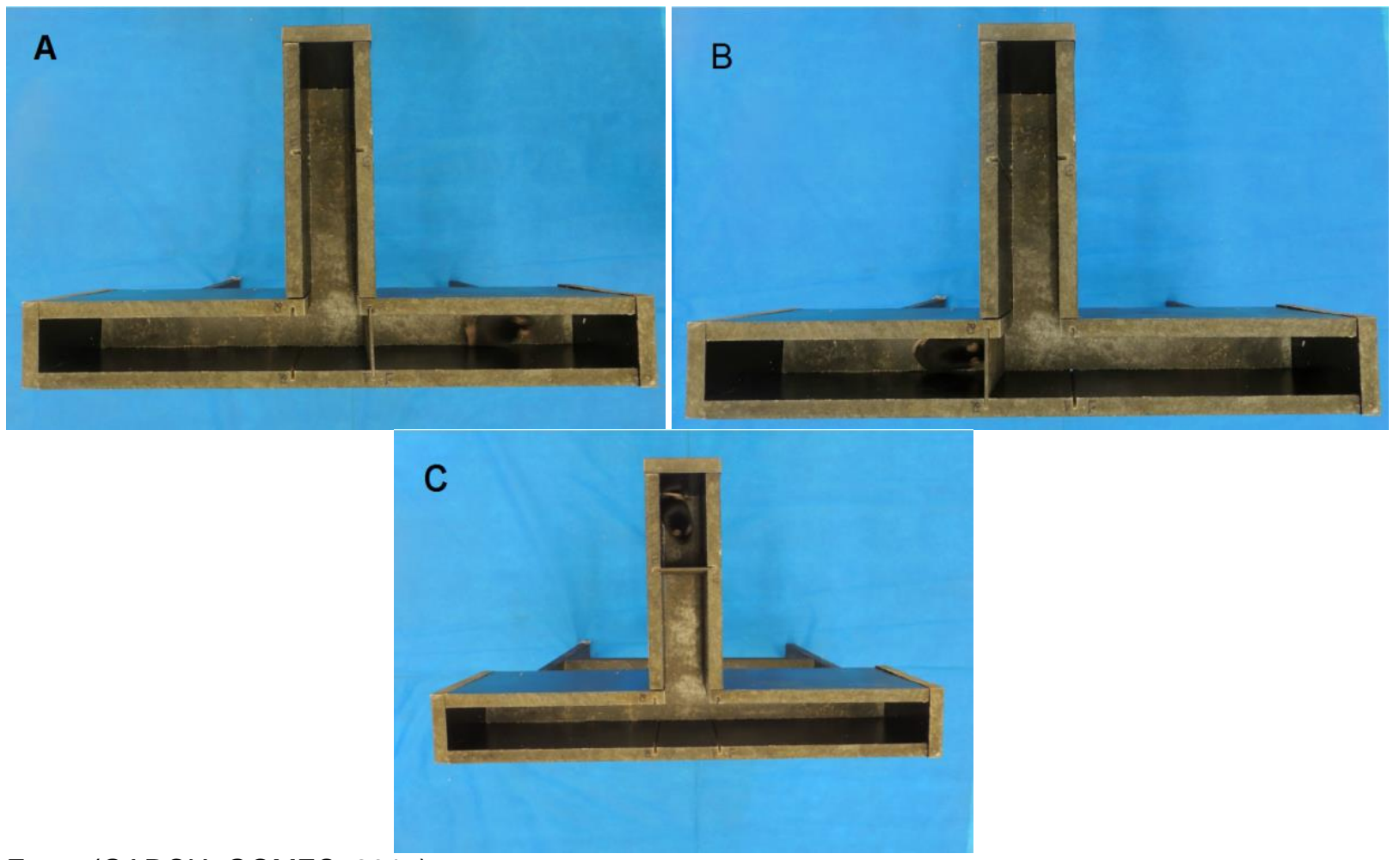

Fonte:(GARCIA-GOMES, 2017). 


\subsubsection{Teste de Natação Forçada}

A natação forçada é um teste comportamental para roedores usado para avaliação de drogas antidepressivas, eficácia antidepressiva de novos compostos e estudos experimentais que visam à elucidação ou prevenção de estados do tipo depressivo. Resumidamente, o protocolo consistiu em submeter o camundongo a uma situação inescapável colocando-o em um tanque transparente, contendo água limpa entre 24 e $26^{\circ} \mathrm{C}$ e uma profundidade de $40 \mathrm{~cm}$, conforme ilustrado na figura 17 (CAN et al., 2012a). Cada camundongo permaneceu por 6 minutos no tanque, e durante o teste foi avaliado o seu comportamento; o teste foi filmado para posterior análise por uma câmera posicionada a $1 \mathrm{~m}$ de distância da borda do tanque, e 1,5 m de altura. Após o término do teste, cada animal era seco com uma toalha e mantido aquecido. Os parâmetros analisados foram a latência para a primeira imobilidade e o tempo de imobilidade total durante o teste.

Figura 17 - Foto representativa da cuba utilizada para realização do teste de natação forçada.

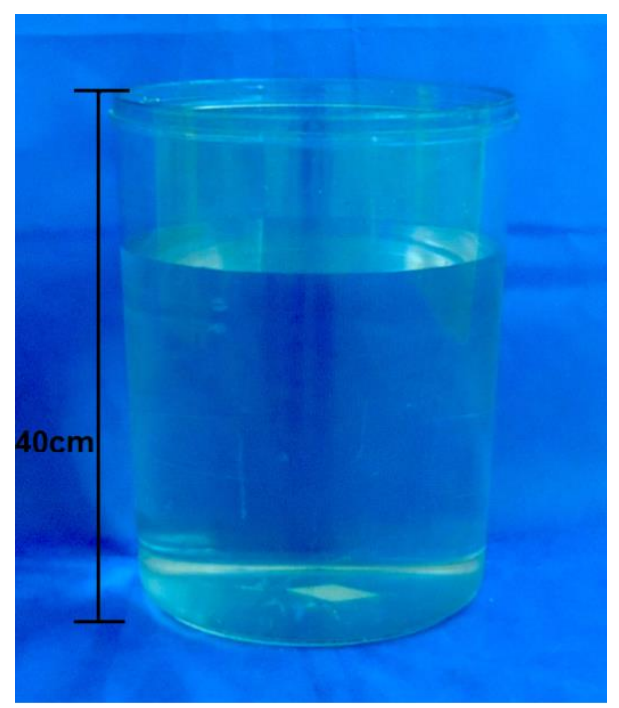

Fonte: (GARCIA-GOMES, 2017). 


\subsubsection{Teste de Suspensão pela cauda}

Este teste foi inicialmente proposto para avaliar efeitos de medicamentos antidepressivos em camundongos (CAN et al., 2012b) sendo também considerado como um modelo de depressão. Nesse teste o camundongo ficava pendurado com a cauda presa em um gancho, com a ajuda de uma fita adesiva, a aproximadamente $25 \mathrm{~cm}$ do chão, como ilustra a figura 18. Os camundongos ficavam 6 minutos pendurados e durante esse tempo foram medidos: a latência para a primeira imobilidade, e o tempo total de imobilidade durante o teste. O teste foi filmado por uma câmera posicionada a $1 \mathrm{~m}$ do aparato para posterior análise.

Figura 18 - Foto representativa do aparato utilizado para realizar o teste de suspensão pela cauda.

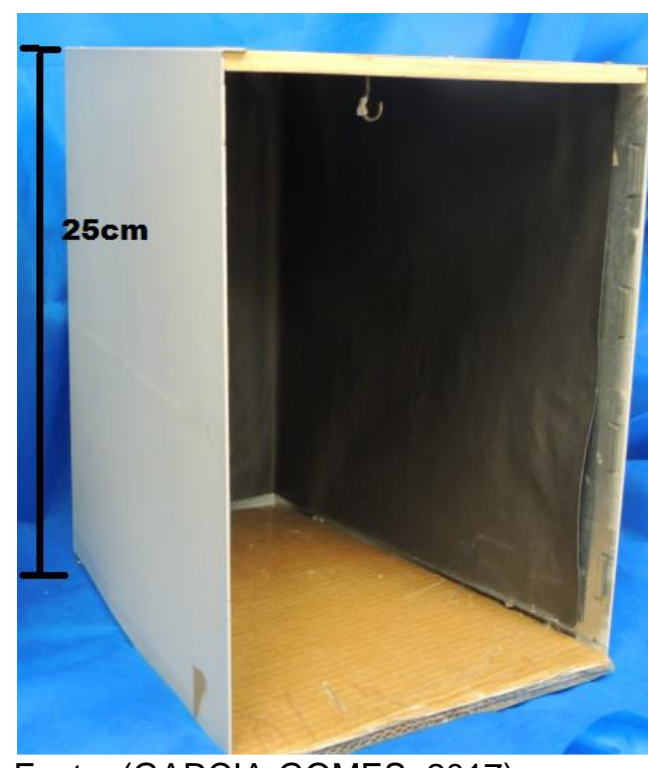

Fonte: (GARCIA-GOMES, 2017).

\subsubsection{Análise estatística}

Os resultados obtidos nos testes de desenvolvimento pós-natal e comportamentais foram submetidos a análise estatística utilizando testes para comparação de médias (Student $t$ test) e medianas (teste $U$ de Mann Witney) por meio do programa GraphPadPrism 5.03. A probabilidade de 5\% $(p<0,05)$ foi considerada capaz de evidenciar diferenças significativas entre os grupos. 


\subsection{RESULTADOS}

\subsubsection{Desenvolvimento pós-natal}

Foram analisados 68 filhotes (machos e fêmeas) provenientes das 9 ninhadas (geradas pelos cruzamentos de machos homozigotos tremor (-/-) com fêmeas heterozigotas para a mutação (+/-). Quatro camundongos não tiveram seus dados contabilizados pois morreram antes do dia do desmame, então não foi possível determinar se eram portadores da mutação ou não.

\subsubsection{Avaliação do desenvolvimento físico}

O teste t de Student não mostrou diferenças significativas nos parâmetros do desenvolvimento físico pós-natal analisados, ou seja, erupção dos incisivos inferiores $(p=0,0982 ; t=1,305 ; d f=66)$, erupção dos incisivos superiores $(p=0,0650$; $t=1,533 ; d f=66)$, e abertura dos olhos ( $p=0,1399 ; t=1,090 ; d f=66)$. Não foi possível realizar o teste $t$ de Student do parâmetro "pelagem completa", pois não houve desvio padrão dentro dos grupos.

O teste t de Student não mostrou diferenças significativas no desenvolvimento sexual dos camundongos tremor quando comparados aos seus controles (tabela 1). 
Tabela 1 - Resultados da análise do desenvolvimento físico pós-natal e sexual dos camundongos Swiss (controle) e Swiss tremor. Os dados foram contabilizados pelo dia que o parâmetro foi observado; e estão demonstrados em média e respectivo erro-padrão.

\begin{tabular}{llll}
\hline \multicolumn{4}{c}{ Grupos } \\
\hline Desenvolvimento físico pós- & $\begin{array}{l}\text { Swiss (controle) } \\
(\mathbf{n}=\mathbf{3 4 )}\end{array}$ & $\begin{array}{l}\text { Swiss tremor } \\
(\mathbf{n}=\mathbf{3 4})\end{array}$ & Valor de $\mathbf{p}$ \\
\hline Desdobramento das orelhas & $4,73 \pm 0,83$ & $4,5 \pm 0,82$ & 0,1224 \\
Incisivos inferiores & $8 \pm 0,68$ & $8 \pm 0,61$ & 0,0982 \\
Incisivos superiores & $10 \pm 0,69$ & $10 \pm 0,73$ & 0,065 \\
Abertura dos olhos & $13 \pm 0,89$ & $13 \pm 0,89$ & 0,1399 \\
Pelagem completa & $8 \pm 0$ & $8 \pm 0$ & - \\
Abertura vaginal & $25,78 \pm 0,42(n=10)$ & $25,86 \pm 0,66(n=10)$ & 0,2039 \\
Descida dos testículos & $20,33 \pm 0,78(n=10)$ & $20,08 \pm 0,67(n=10)$ & 0,3686 \\
\hline
\end{tabular}

Fonte: (GARCIA-GOMES, 2017).

Em relação ao ganho de peso dos camundongos do nascimento até o desmame foram observadas diferenças significativas entre os mutantes e seus controles somente no dia 21PN, apontadas pelo teste $t$ de Student (tabela 2). Já no comprimento, em centímetros, não foram observadas diferenças significativas ao longo do período analisado, segundo o teste t de Student (tabela 2).

Tabela 2 - Resultados obtidos a partir da medição do peso(g) e do comprimento(cm) dos filhotes Swiss (controle) e Swiss tremor. Os dados estão representados em média e respectivo erro-padrão.

\begin{tabular}{llll}
\hline \multicolumn{3}{c}{ Grupos } \\
\hline Medidas & $\begin{array}{l}\text { Swiss (controle) } \\
(\mathbf{n}=\mathbf{3 4})\end{array}$ & $\begin{array}{l}\text { Swiss tremor } \\
(\mathbf{n}=\mathbf{3 4})\end{array}$ & Valor de P \\
\hline Peso (g) 6PN & $4,30 \pm 0,55$ & $4,44 \pm 0,56$ & 0,1587 \\
Comprimento (cm) 6PN & $4,41 \pm 0,21$ & $4,37 \pm 0,20$ & 0,2115 \\
Peso (g) 13PN & $7,46 \pm 0,99$ & $7,45 \pm 0,89$ & 0,4796 \\
Comprimento (g) 13PN & $5,56 \pm 0,29$ & $5,56 \pm 0,26$ & 0,4826 \\
Peso (g) 21PN & $12,65 \pm 1,78$ & $11,75 \pm 1,44^{*}$ & $0,0121^{*}$ \\
Comprimento (cm) 21PN & $6,85 \pm 0,34$ & $6,79 \pm 0,38$ & 0,2537 \\
\hline
\end{tabular}

Fonte: (GARCIA-GOMES, 2017).

\subsubsection{Avaliação dos reflexos durante o desenvolvimento}

O teste $t$ de Student não demonstrou diferenças significativas entre os grupos na análise do reflexo de preensão palmar ( $\mathrm{p}=0,4338 ; \mathrm{t}=0,1673$; $\mathrm{df}=66)$, no reflexo de endireitamento de postura $(p=0,5000 ; t=0,0 ; d f=66)$ e no surgimento do reflexo de sobressalto $(p=0,4007 ; t=0,2531 ; d f=66)$ conforme pode ser observado na tabela 3 . 
$\mathrm{Na}$ avaliação do reflexo de geotaxia negativa não foi possível realizar o teste $t$ de Student pois não havia desvio padrão no grupo tremor (tabela 3).

Tabela 3 - Resultados da análise dos reflexos em camundongos Swiss (controle) e Swiss tremor. Os dados são contabilizados pelo dia que o parâmetro ocorreu (com exceção do reflexo de preensão palmar; que foi medido o dia que o filhote o perdeu), e estão demonstrados em média e respectivo erro-padrão

\begin{tabular}{llll}
\hline & \multicolumn{3}{c}{ Grupos } \\
\hline Reflexos & Swiss (controle) & $\begin{array}{l}\text { Swiss tremor } \\
(\mathbf{n}=\mathbf{3 4 )}\end{array}$ & Valor de $\mathbf{P}$ \\
\hline Preensão Palmar & $7 \pm 1,28$ & $7 \pm 1,60$ & 0,4338 \\
Endireitamento de Postura & $5 \pm 0,29$ & $5 \pm 0,29$ & 0,50 \\
Geotaxia Negativa & $4 \pm 0,34$ & $4 \pm 0$ & - \\
Sobressalto & $12 \pm 0,51$ & $11,96 \pm 0,62$ & 0,4007 \\
\hline
\end{tabular}

Fonte: (GARCIA-GOMES, 2017).

\subsubsection{Testes Comportamentais}

\subsubsection{Atividade geral em campo aberto}

O teste t de Student não demonstrou diferenças significativas nos seguintes parâmetros analisados no teste de atividade motora em campo aberto no dia 21PN: locomoção (tabela 4) ( $\mathrm{p}=0,1893 ; \mathrm{t}=0,8885 ; \mathrm{df}=50)$, número de bolos fecais (defecação; $p=0,1968 ; t=0,8607 ; d f=50$ ), e número de poças de urina (micção; $p=0,1068 ; t=1,261 ; d f=46)$. Os únicos parâmetros que apresentaram diferenças estatísticas significativas entre os dois grupos foram: o número de eventos de auto limpeza $(p<0,0001 ; t=4,336 ; d f=50$, tabela 4), no qual o grupo mutante apresentou aumento em relação ao grupo controle; - e a frequência de levantar (o animal se apoia sob os membros posteriores ou na parede do campo; $p=0,0015 ; t=3,122$; $\mathrm{df}=50$ ) no qual o grupo mutante apresentou diminuição em relação ao grupo controle, tabela 4. Para esse teste os animais não foram separados por sexo, pois foram analisados na fase pré-púbere. Os resultados que apresentaram diferenças significativas estão representados na figura 19. 
Tabela 4 - Resultados dos parâmetros de atividade geral observados no teste de campo aberto, realizado no dia 21PN dos camundongos Swiss (controle) e Swiss tremor, representados em média e respectivos erro-padrão Os parâmetros grooming, levantar, defecação e micção foram contabilizados em número de eventos, e a locomoção foi medida em segundos.

\begin{tabular}{llll}
\hline \multicolumn{3}{c}{ Grupos } \\
\hline Parâmetros & Swiss (controle) $(\mathbf{n = 2 6 )}$ & Swiss tremor $(\mathbf{n}=\mathbf{2 6})$ & Valor de $\mathbf{p}$ \\
\hline Locomoção & $248,04 \pm 41,34$ & $256,27 \pm 22,84$ & 0,1893 \\
Grooming & $2,96 \pm 2,66$ & $9,54 \pm 7,26^{* * *}$ & $<0,0001$ \\
Levantar & $55,34 \pm 24,45$ & $36,11 \pm 19,70^{* *}$ & 0,0015 \\
Defecação & $0,38 \pm 0,75$ & $0,23 \pm 0,51$ & 0,1968 \\
Micção & $1,29 \pm 1,16$ & $0,92 \pm 0,88$ & 0,1068 \\
\hline
\end{tabular}

Fonte: (GARCIA-GOMES, 2017).

Figura 19 - Parâmetros analisados Swiss (controle) e Swiss tremor no teste de atividade geral em campo aberto, realizado no dia 21PN. Os dados foram apresentados em média e respectivos errospadrão. Teste t de Student. A - grooming- ${ }^{* * *} \mathrm{p}<0,0001 ; \mathrm{B}-$ levantar ${ }^{* *} \mathrm{p}=0,0015$

A

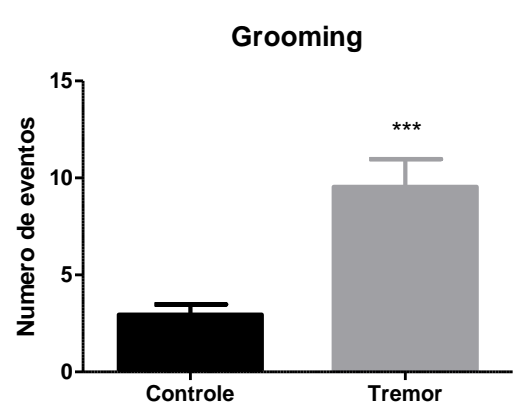

Fonte: (GARCIA-GOMES, 2017).
B

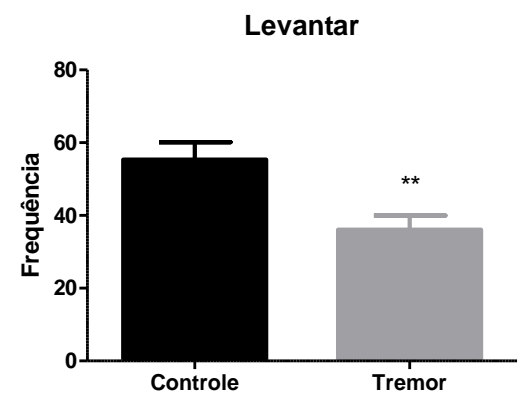

A tabela 5 mostra os resultados obtidos no teste de atividade geral em campo aberto realizado no dia 60PN. Nesse teste os camundongos foram separados por sexo para que não houvesse interferência nos resultados devido às mudanças hormonais após a puberdade. Foram observadas diferenças significativas, a partir da análise com o teste $t$ de Student, no número de poças de micção no grupo dos machos: $(p=0,0334 ; t=2,359 ; d f=16$, figura 20A) e das fêmeas $(p=0,0362 ; t=2,286$; $d f=16$, figura 20B); frequência de levantar também do grupo dos machos $(p<0,0001$; $t=11,99$; $d f=16$, figura $20 C$ ) e das fêmeas $(p<0,0001 ; t=13,12 ; d f=16$, figura 20D). $O$ grupo dos machos tremor também apresentou diminuição na frequência de grooming quando comparado ao grupo controle $(p=0,0409 ; t=2,223$; $d f=16$, figura 20E). Não foram observadas diferenças nos outros parâmetros; defecação dos 
machos $(p=0,5483 ; t=0,6151 ; d f=14)$ ou das fêmeas $(p=0,1875 ; t=1,377 ; d f=16)$, grooming das fêmeas $(p=0,5202 ; t=0,6597 ; d f=16)$, ou no tempo de locomoção dos machos $(p=0,5259 ; t=0,6484 ; d f=16)$ ou das fêmeas $(p=0,2752 ; t=1,130 ; d f=16)$. As diferenças significativas estão apresentadas na figura 20.

Tabela 5 - Resultados dos parâmetros observados no teste de atividade geral em campo aberto realizado no dia 60PN, dos camundongos Swiss (controle) e Swiss tremor, de ambos os sexos. Os valores são apresentados em média e respectivo erro-padrão

\begin{tabular}{|c|c|c|c|c|}
\hline Atividade Geral & $\begin{array}{l}\text { Swiss } \\
\text { (controle) }{ }^{\top} \\
(\mathbf{n}=10)\end{array}$ & $\begin{array}{l}\text { Swiss } \\
\text { tremor ठৃ } \\
(\mathrm{n}=10)\end{array}$ & $\begin{array}{l}\text { Swiss } \\
\text { (controle)우 } \\
(n=10)\end{array}$ & $\begin{array}{l}\text { Swiss 우 } \\
\text { tremor }(n=10)\end{array}$ \\
\hline Micção (número de poças) & $2 \pm 1,99$ & $0,3 \pm 0,71^{*}$ & $1 \pm 1,12$ & $0,1 \pm 0,3^{*}$ \\
\hline Defecação (Número de cíbalas) & $3 \pm 3,23$ & $3 \pm 3,53$ & $3 \pm 1,56$ & $2 \pm 1,80$ \\
\hline Frequência de Levantar & $70 \pm 13,80$ & $8 \pm 7,31^{\star \star *}$ & $68 \pm 10,65$ & $10 \pm 7,72^{* \star *}$ \\
\hline Frequência de Grooming & $4 \pm 3,77$ & $1 \pm 0,97^{*}$ & $7 \pm 4,49$ & $5 \pm 3,38$ \\
\hline Tempo de Locomoção (segundos) & $261 \pm 8,21$ & $264 \pm 13,66$ & $259 \pm 10,55$ & $237 \pm 53,88$ \\
\hline
\end{tabular}

Fonte: (GARCIA-GOMES, 2017). 
Figura 20 - Parâmetros analisados dos camundongos Swiss (controle) e Swiss tremor de ambos os sexos no teste de atividade geral em campo aberto- 60PN. Realizado no dia 60PN. Os dados são apresentados em média e respectivos erros-padrão. A - ${ }^{*} p=0,0334$; $B$ - ${ }^{*} p=0,0362$; $C$ e $D$ ${ }^{* \star *} p<0,0001 ; E-{ }^{*} p=0,0409$.
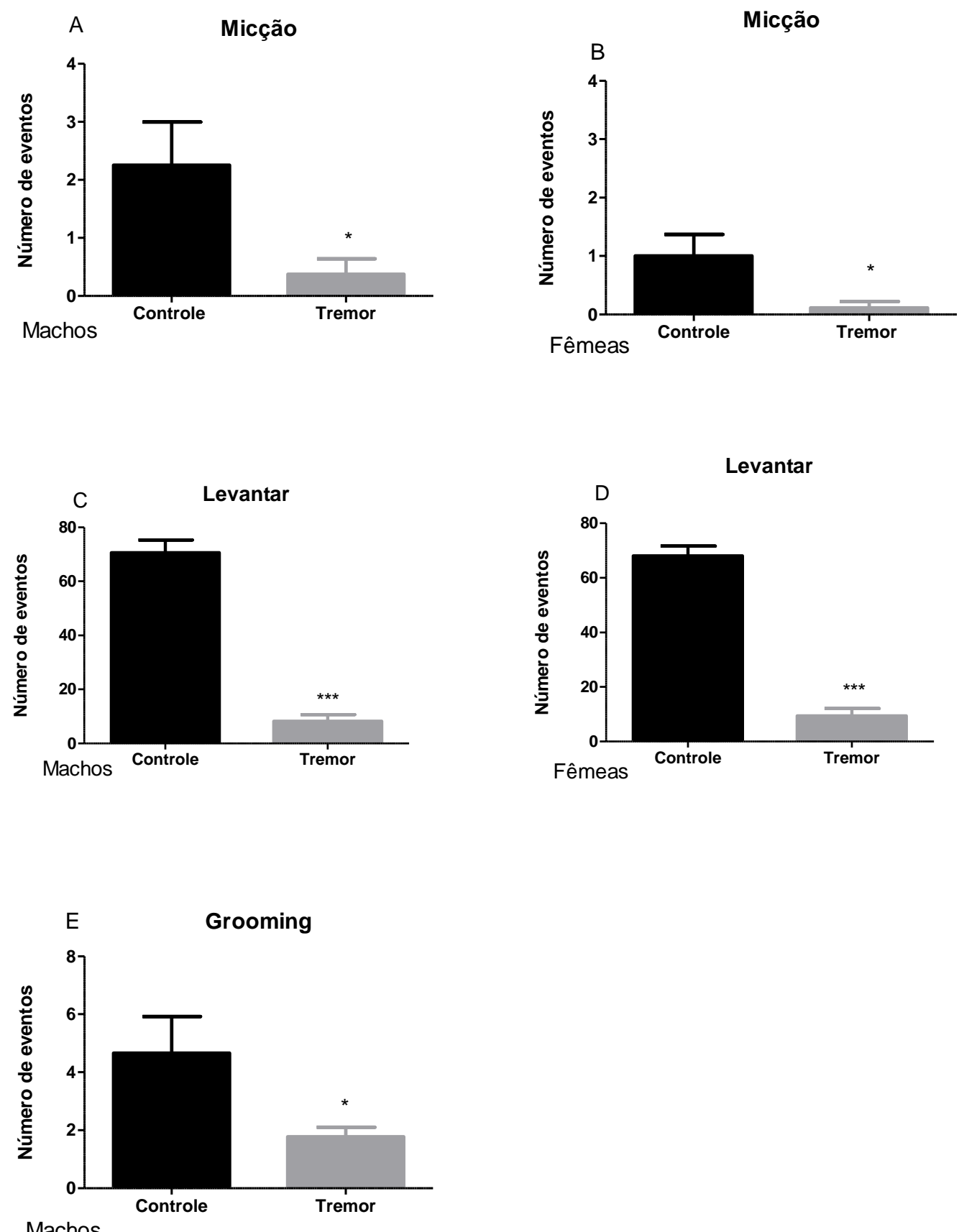

Fonte: (GARCIA-GOMES, 2017) 
A tabela 6 apresenta os resultados, em porcentagem por escore, dos parâmetros comportamentais que avaliam o sistema sensorial dos mutantes tremor em relação ao grupo controle. $O$ teste $U$ de Mann-Witney não indicou diferenças significativas.

Tabela 6 - Resultados observados a partir da análise de sistema sensorial dos camundongos Swiss (controle) e Swiss tremor, de ambos os sexos, aos 60 dias de idade. Os dados são apresentados em mediana (valor mínimo e máximo).

\begin{tabular}{|c|c|c|c|c|c|c|}
\hline Sistema Sensorial & $\begin{array}{l}\text { Swiss } \\
\text { (controle) } \\
\sigma^{\top}(n=10) \\
\end{array}$ & $\begin{array}{l}\begin{array}{l}\text { Swiss } \\
\text { tremor ठৃ } \\
(\mathrm{n}=10)\end{array} \\
\end{array}$ & $\begin{array}{l}\text { valor de } \\
\text { p }\end{array}$ & $\begin{array}{l}\text { Swiss } \\
(\text { controle }) \text { 우 } \\
(\mathrm{n}=10)\end{array}$ & $\begin{array}{l}\text { Swiss 우 } \\
\text { tremor } \\
(\mathrm{n}=10)\end{array}$ & $\begin{array}{l}\text { valor de } \\
\text { p }\end{array}$ \\
\hline Frêmito vocal & Não & Não & - & Não & Não & - \\
\hline Irritabilidade & $2 / 10$ & $2 / 10$ & 0,9512 & $1 / 9$ & $1 / 9$ & 0,9355 \\
\hline Reflexo auricular & $2(0-4)$ & $3(0-4)$ & 0,1348 & $3(0-4)$ & $2,5(0-4)$ & 0,8559 \\
\hline Aperto de cauda & $3(0-4)$ & $3(0-4)$ & 0,2169 & $4(0-4)$ & $2(0-4)$ & 0,1015 \\
\hline Reflexo corneal & $4(0-4)$ & $3(0-4)$ & 0,8815 & $4(0-4)$ & $4(0-4)$ & 0,915 \\
\hline Resposta ao toque & $1(0-4)$ & $1(0-4)$ & 0,3025 & $1(0-4)$ & $1(0-4)$ & 0,8113 \\
\hline
\end{tabular}

Fonte: (GARCIA-GOMES, 2017).

O quadro 5 apresenta os resultados dos testes psicomotores utilizados para a avaliação dos parâmetros comportamentais analisados no campo aberto. Não foram observadas diferenças entre as respostas dos grupos analisados.

Quadro 5 - Resultados observados a partir da análise dos parâmetros psicomotores em camundongos Swiss (controle) e Swiss tremor em ambos os sexos.

\begin{tabular}{|l|l|l|l|l|}
\hline & $\begin{array}{l}\text { Swiss } \\
(\text { controle }) \\
(\mathbf{n}=10)\end{array}$ & $\begin{array}{l}\text { Swiss tremor } \\
\sigma^{\top}(\mathbf{n = 1 0})\end{array}$ & $\begin{array}{l}\text { Swiss } \\
(\text { controle }) \\
\text { o+ }(\mathbf{n = 1 0})\end{array}$ & $\begin{array}{l}\text { Swiss } \text { ㅇ tremor } \\
(\mathbf{n = 1 0})\end{array}$ \\
\hline Trem Posterior & Não & Não & Não & Não \\
\hline Reflexo de Endireitamento & Sim & Sim & Sim & Sim \\
\hline Tônus Corporal & Sim & Sim & Sim & Sim \\
\hline Força de Agarrar & Sim & Sim & Sim & Sim \\
\hline
\end{tabular}

Fonte: (GARCIA-GOMES, 2017). 
Observou-se a ocorrência de tremores, de cauda em pé, e ataxia em todos camundongos mutantes de ambos os sexos, conforme mostra o quadro 6.

Quadro 6 - Resultados observados a partir da análise dos parâmetros do sistema nervoso central nos camundongos Swiss (controle) e Swiss tremor de ambos os sexos.

\begin{tabular}{|l|l|l|l|l|}
\hline $\begin{array}{l}\text { Sistema Nervoso } \\
\text { Central }\end{array}$ & $\begin{array}{l}\text { Swiss (controle) } \\
\sigma^{\top}(\mathbf{n = 1 0})\end{array}$ & $\begin{array}{l}\text { Swiss tremor o⿱ } \\
(\mathbf{n}=10)\end{array}$ & $\begin{array}{l}\text { Swiss } \\
(\text { controle }) \text { 우 } \\
(\mathbf{n}=10)\end{array}$ & $\begin{array}{l}\text { Swiss 우 } \\
\text { tremor }(\mathbf{n}=10)\end{array}$ \\
\hline Tremores & Não & Sim & Não & Sim \\
\hline Cauda em pé & Não & Sim & Não & Sim \\
\hline Ataxia & Sim & Sim & Sim & Sim \\
\hline
\end{tabular}

Fonte: (GARCIA-GOMES, 2017).

\subsubsection{Ansiedade no Labirinto em Cruz Elevada}

Para o teste de ansiedade no Labirinto em Cruz Elevada foram utilizados somente os camundongos machos, sendo 8 mutantes e 8 controles por grupo. A tabela 7 mostra a comparação entre as respostas dos animais controle em relação aos mutantes; a análise realizada com 0 teste $\mathrm{t}$ de Student não evidenciou diferenças significativas na porcentagem de tempo que os animais passaram nos braços abertos em relação aos braços fechados ( $p=03943 ; t=0,8788$; $d f=14$ ), na porcentagem do número de entradas nos braços abertos em relação aos fechados $(p=0,6783 ; t=0,4235 ; d f=14)$ ou no tempo de permanência nos braços abertos $(p=0,5713 ; t=0,5798 ; d f=14)$ ou nos braços fechados $(p=0,3734 ; t=0,9195 / d f=14)$ mas mostrou diferenças no número de entradas nos braços abertos $(p=0,0006$; $t=4,403 ; d f=14$, figura $21 \mathrm{~A})$ e nos braços fechados $(p=0,0062 ; t=3,216 ; d f=14$, figura 21B). As diferenças significativas são apresentadas na figura 21.

Tabela 7 - Respostas dos camundongos machos Swiss (controle) e Swiss tremor no teste de ansiedade no Labirinto em Cruz Elevada. Os valores estão representados em média e respectivos erro-padrão.

\begin{tabular}{lll}
\hline & Swiss (controle) $\sigma^{7}(\mathbf{n}=8)$ & Swiss o $^{7}$ tremor $(\mathbf{n}=8)$ \\
\hline \% Tempo BA & $22 \pm 7,14$ & $33 \pm 34,33$ \\
\% Entradas BA & $43 \pm 6,60$ & $41 \pm 19,02$ \\
№ entradas BA & $9 \pm 2,65$ & $3 \pm 2,22{ }^{* \star \star}$ \\
№ entradas BF & $12 \pm 5,15$ & $4 \pm 2,80^{\star *}$ \\
Tempo BA (segundos) & $58 \pm 18,63$ & $72 \pm 65,07$ \\
Tempo BF (segundos) & $204 \pm 23,89$ & $173 \pm 92,31$ \\
\hline
\end{tabular}

Fonte: (GARCIA-GOMES, 2017). 
Figura 21 - Respostas dos camundongos machos Swiss (controle) e Swiss tremor no teste de ansiedade em cruz elevada. São apresentadas as distribuições dos dois grupos. Teste t de Student. $A-{ }^{* * *} p=0,0006 ; B-{ }^{* *} p=0,0062$. $N=8 /$ grupo.
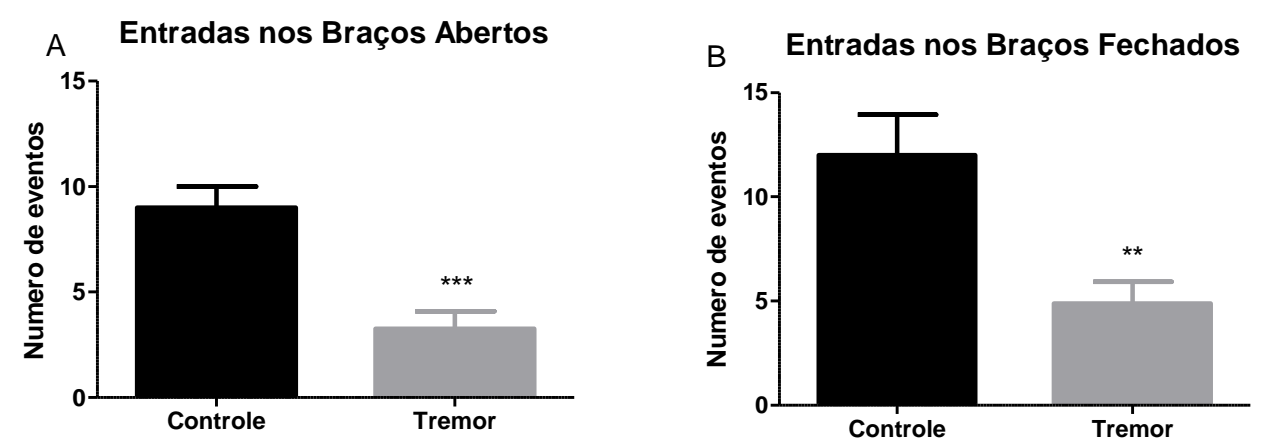

Fonte: (GARCIA-GOMES, 2017).

\subsubsection{Coordenação Motora em Trave Elevada}

A figura 22 ilustra as respostas dos camundongos machos dos grupos Swiss (controle) e Swiss tremor no teste de coordenação motora em trave elevada. O teste U de Mann-Witney indicou redução significante nos escores da trave elevada dos animais mutantes em relação ao grupo controle $(p=0,0001)$.

Figura 22 - Respostas dos camundongos machos Swiss (controle) e Swiss tremor no teste de coordenação motora em trave elevada. São apresentadas as distribuições dos dois grupos. ${ }^{* * *} p$ $=0,0001$ em relação ao grupo controle (teste $U$ de Mann-Witney). $N=8 / g r u p o$.

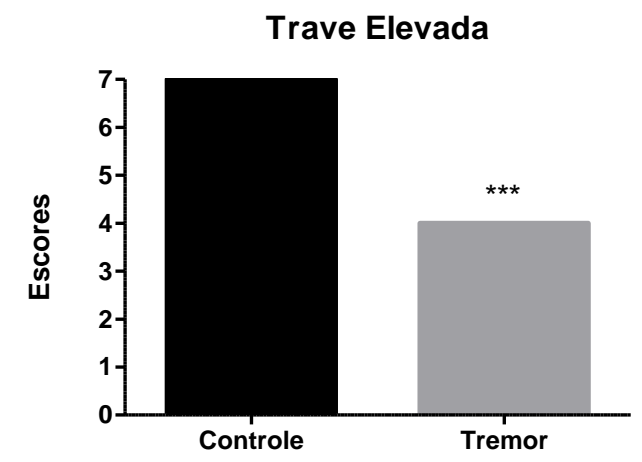

Fonte: (GARCIA-GOMES, 2017). 


\subsubsection{Memória em Labirinto em T}

A figura 23 ilustra o comportamento de camundongos mutantes tremor machos Swiss e seus respectivos controles no teste de alternância espontânea em Labirinto em T. O teste $U$ de Mann-Witney não indicou diferenças significativas entre as respostas dos animais mutantes e de seu grupo controle $(p=0,4117 \mathrm{U}=31,50)$.

Figura 23 - Comportamento de camundongos machos Swiss (controle) e Swiss tremor no teste de alternância espontânea em Labirinto em T. Os dados são apresentados em média e respectivos erros-padrão. Teste $\mathrm{U}$ de Mann-Witney. $\mathrm{N}=8 /$ grupo.

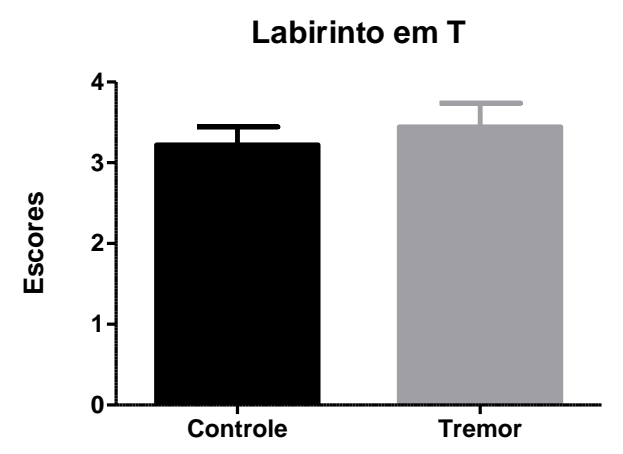

Fonte: (GARCIA-GOMES, 2017).

\subsubsection{Natação Forçada}

A figura 24 mostra as respostas de depressão dos camundongos machos mutantes tremor Swiss e o respectivo grupo controle no teste de natação forçada. O teste t de Student evidenciou diferenças significativas na imobilidade total; o grupo tremor apresentou diminuição no tempo de imobilidade em relação ao grupo controle $(p<0,0001 ; t=6,892 ; d f=14$, figura 24) mas não evidenciou diferenças na latência para a primeira imobilidade $(p=0,0949 ; t=1,827 ; d f=13)$ dos animais no teste. 
Figura 24 - Comportamento de camundongos machos Swiss (controles) e Swiss tremor no teste de natação forçada. Os dados são apresentados em média e respectivo erro-padrão. Teste t de Student. $\mathrm{N}=8 /$ grupo. ${ }^{* \star *} \mathrm{p}<0,0001$.

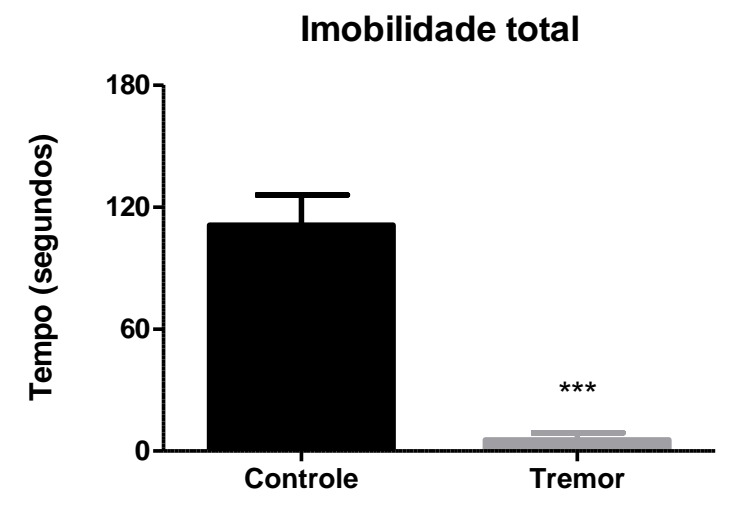

Fonte: (GARCIA-GOMES, 2017).

\subsubsection{Suspensão pela cauda}

A figura 25 mostra as diferenças evidenciadas pelo teste de $t$ de Student no tempo de imobilidade total no teste $(p<0,0001 ; t=6,676 \mathrm{df}=14$, figura 25$)$. Não foram evidenciadas diferenças no tempo de latência para a primeira imobilidade $(p=0,8696$; $\mathrm{t}=0,1672$; $d f=14$, figura 25 ).

Figura 25 - Comportamento de camundongos machos Swiss (controle) e Swiss tremor no teste de suspensão pela cauda. Os dados são apresentados em média e respectivo erro-padrão. Teste t de Student. $N=8 /$ grupo. ${ }^{* * *} \mathrm{p}<0,0001$.

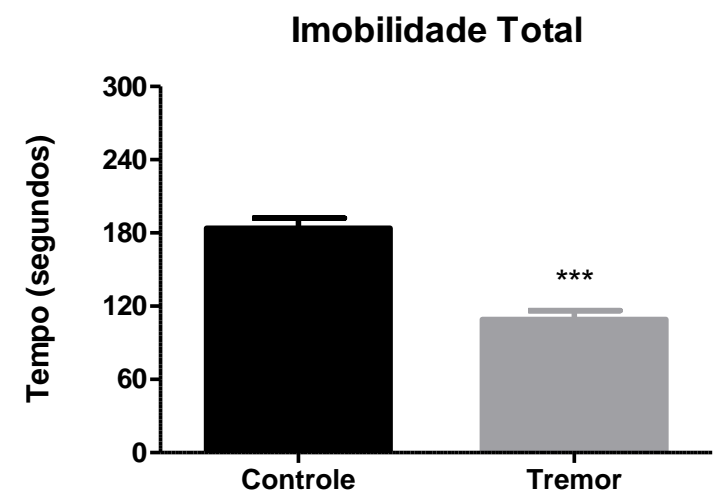

Fonte: (GARCIA-GOMES, 2017). 


\subsection{DISCUSSÃO}

A característica mais evidente nos camundongos mutantes, que permite diferenciá-los dos animais controle, na terceira semana de vida, foram os tremores observados durante a locomoção na gaiola moradia. Enquanto os camundongos normais movimentam-se rapidamente pela gaiola, os camundongos mutantes tendem a ficar mais parados e, quando estimulados a se movimentar, apresentam ataxia e tremores em todo o corpo. Ocasionalmente, ocorrem convulsões, que podem ser induzidas por meio de estímulos audiogênicos. Ao longo das semanas os tremores tornam-se mais intensos e a locomoção dos animais mutantes fica mais incoordenada.

Os resultados dos testes de desenvolvimento pós-natal demostraram que, exceto no peso aos 21PN, não houve diferença significativa em nenhum dos parâmetros analisados, confirmando as observações iniciais sobre o fenótipo do camundongo mutante. No entanto, ainda serão necessários estudos mais detalhados, incluindo testes moleculares e avaliação histopatológica, para averiguar possíveis alterações morfológicas e funcionais durante a fase de desenvolvimento pré e pós-natal dos mutantes tremor.

Concomitantemente à caracterização fenotípica do camundongo mutante, iniciaram-se os estudos genéticos visando identificar a mutação. Resultados preliminares do mapeamento genético utilizando marcadores microssatélites distribuídos pelo genoma do camundongo indicaram que a mutação tremor encontra-se no cromossomo 14, na região entre 33,21 e 38,21 cM, tendo como possível candidato o gene Egr3, um dos fatores de transcrição da família zinc-finger, envolvidos na inervação e formação do fuso mitótico (GARCIA GOMES et al., 2016).

Além dos testes de desenvolvimento pós-natal, os camundongos Swiss e Swiss tremor foram submetidos ao teste de campo aberto no $21^{\circ}$ dia PN, no qual tiveram a sua atividade geral observada e analisada; e os resultados indicaram que os mutantes apresentaram maior frequência de grooming e maior locomoção mesmo que a ultima não tenha apontado diferenças significativas - do que os animais controle, mostrando assim maior exploração do ambiente novo. Quanto à diminuição da frequência de levantar em relação ao grupo controle podemos aventar que ela se deve ao déficit motor desses animais. No teste de atividade geral em 
campo aberto realizado aos 60 dias, foi observada diminuição na frequência de levantar e de grooming de ambos os sexos, apesar da frequência de grooming no grupo das fêmeas não ter apresentado diferença estatística significante. A redução na frequência de levantar dos camundongos mutantes foi semelhante aos resultados observados no teste de atividade geral em campo aberto realizado aos 21 dias de vida; no entanto, a frequência de grooming estava reduzida nos mutantes no dia $60 \mathrm{PN}$, possivelmente devido ao agravamento do déficit motor.

Nos testes de natação forçada e de suspensão pela cauda observou-se redução no tempo total de imobilidade dos camundongos tremor em relação ao grupo controle, que pode ser interpretado como hiperatividade dos animais mutantes. . Esses resultados fortalecem a hipótese dos estudos genéticos de que o gene candidato seria o Egr3; uma vez que camundongos mutantes homozigotos recessivos de diferentes fundos genéticos (TOURTELLOTTE \& MILBRANDT, 1998) para esse gene apresentaram hiperatividade e locomoção exagerada - em comparação ao grupo controle - quando expostos a ambientes novos (GALLITANOMENDELL et.al., 2007).

Também foi demonstrado que o gene Egr3 está associado com a modulação de receptores GABA-érgicos no hipocampo (BROOKS-KAYAL et al., 2009), sendo que sua super-expressão foi relacionada com a susceptibilidade à convulsões audiogênicas em modelos animais (LÓPEZ-LÓPEZ et al., 2016). O mesmo mecanismo poderia explicar as crises convulsivas observadas no mutante tremor, contudo serão necessários estudos mais detalhados para elucidar a patogenia dessas convulsões.

O exame neurológico compreende as seguintes etapas: nível de consciência, atenção, comportamento, postura, marcha e movimento espontâneo, trofismo muscular, tônus muscular, sensibilidades dolorosa e tátil, funções básicas dos nervos cranianos (principalmente oculomotora e mastigatória), integridade dos reflexos espinais, teste de reações ou reflexos posturais e provas comportamentais específicas. No camundongo, contudo, muitos de tais itens são de difícil qualificação, sendo muito comum o uso da descrição comparativa e indireta por testes comportamentais e motores para definição de cada um dos componentes (PINTO et. al., 2013). Nesse sentido, os testes comportamentais empregados no presente estudo permitiram avaliar a capacidade motora e sensorial dos camundongos mutantes tremor. 
Em relação ao comportamento nos animais adultos, a partir do 60 dia PN, as diferenças marcantes dos mutantes em relação aos camundongos Swiss normais foram observadas nos testes de ansiedade em labirinto em cruz elevada, coordenação motora em trave elevada, respostas comportamentais no teste de nado forçado e no teste de suspensão pela cauda.

No teste de ansiedade e no teste de labirinto em cruz elevada observou-se menor número de entradas nos braços abertos e nos braços fechados dos mutantes em comparação aos seus controles. A diminuição do número de entradas mostra apenas que os camundongos tremor apresentaram locomoção inferior aos controles durante o teste, o que sugere que esses animais apresentaram problemas de coordenação motora, o que foi corroborado pela diminuição dos escores no teste de coordenação motora em trave elevada.

No teste da trave elevada os mutantes assumiam uma postura característica agarrando-se com os membros anteriores e enrolando a cauda na trave para manter o equilíbrio. Ao atravessar, esses animais apoiavam o abdômen na trave e se arrastavam por toda a extensão da mesma. Apesar da dificuldade motora para atravessar a trave, os mutantes foram capazes de realizar o teste, o que comprova que esses animais não possuem déficit sensorial que possa interferir na exploração do ambiente em relação aos controles.

Os resultados obtidos até o momento indicaram que o camundongo mutante tremor apresentou proeminente deficiência motora, mas que não demostrou alterações da memória espacial quando comparado ao grupo controle. 
4. CAPÍTULO 2

CARACTERIZAÇÃO COMPORTAMENTAL DO CAMUNDONGO MUTANTE ESPONTÂNEO TREMOR EM FUNDO GENÉTICO C57BL/6 


\subsection{INTRODUÇÃO}

A mutação espontânea tremor, autossômica recessiva, foi identificada na colônia de camundongos Swiss no Biotério do Departamento de Patologia da FMVZ/USP. As principais características fenotípicas observadas nesses mutantes foram alterações neurológicas tais como tremores, ataxia e convulsões tônicas audiogênicas, evidentes a partir de três semanas de vida. Para dar início aos estudos genéticos a mutação foi transferida para a linhagem isogênica C57BL/6 por meio de 10 retrocruzamentos, obtendo-se uma linhagem congênica, conforme ilustra a figura 1.

O mapeamento genético com marcadores microssatélites distribuídos pelo genoma do camundongo indicou que a mutação tremor encontra-se no cromossomo 14, na região entre 33,21 e 38,21 cM, tendo como possível candidato o gene Egr3 (early growth response 3), um dos fatores de transcrição da família zinc-finger, envolvidos na inervação e formação do fuso mitótico. O gene Egr3 é um dos quatro membros da família EGR (early growth response), Egr1, Egr2, Egr3 e Egr4, a saber. Esse gene desempenha um importante papel no crescimento celular e no desenvolvimento neuronal, e também atua na regulação da plasticidade sináptica, ativação neuronal, aprendizado e memória. Além disso, está envolvido em uma grande variedade de processos, incluindo desenvolvimento muscular, desenvolvimento de linfócitos, crescimento e migração de células endoteliais (TOURTELLOTTE \& MILBRANDT, 1998; KIM et al., 2010). Sua transcrição pode ocorrer de forma rápida e transitória, sendo induzida por uma ampla gama de estímulos celulares ambientais, fisiológicos e patológicos. Estudos realizados em camundongos knockout demonstraram que o gene Egr3 está associado com a plasticidade neuronal em resposta ao estresse e a novas situações (GALLITANOMENDEL et al, 2007), com o aprendizado e memória (LI et al, 2007) e com a modulação de receptores GABA-érgicos no hipocampo (ROBERTS et al., 2005). Já a super-expressão do Egr3 foi relacionada com a susceptibilidade a convulsões audiogênicas em modelos animais (LOPÉZ-LOPÉZ et al., 2016).

Paralelamente à identificação dos genes envolvidos e das funções bioquímicas de seus produtos, que fornecem uma parte das informações sobre o fenótipo observado, o objetivo final da descrição de uma mutação é determinar as 
funções do gene no contexto de todo o organismo. Desta forma, a análise comportamental é uma ferramenta importante que auxilia na compreensão dos fenômenos que envolvem alterações fisiológicas e do sistema nervoso. Inicialmente, realiza-se o exame físico dos animais, observando-se aspectos comportamentais simples que são indicativos de saúde geral, tais como: peso corporal, temperatura, aparência da pele e pelos, atividade na gaiola, desempenho reprodutivo, agressão, construção de ninhos, etc. Observam-se também os reflexos neurológicos procurando identificar quaisquer deficiências graves que poderão impedir a realização de outros testes comportamentais. Posteriormente, as tarefas motoras e sensoriais servem para avaliar as habilidades físicas do mutante estudado (CRAWLEY, 2008).

O objetivo desse estudo foi caracterizar o fenótipo dos camundongos mutantes tremor a partir de testes comportamentais que visaram a observação do estado geral de saúde, dos reflexos neurológicos, das habilidades sensoriais e da função motora dos animais em relação aos seus respectivos controles e comparação entre os sexos. Os testes mediram: parâmetros de motilidade, psicomotores, sensoriais e ligados ao sistema nervoso central e autônomo por meio de observação direta dos animais, atividade geral em campo aberto, comportamento em labirinto em cruz elevada para medir ansiedade e memória espacial, coordenação motora em trave elevada, resposta comportamental no teste de natação forçada, resposta comportamental no teste de suspensão pela cauda.

Figura 1 - Esquema representativo dos cruzamentos realizados para que a mutação fosse transferida para o fundo genético C57BL/6.

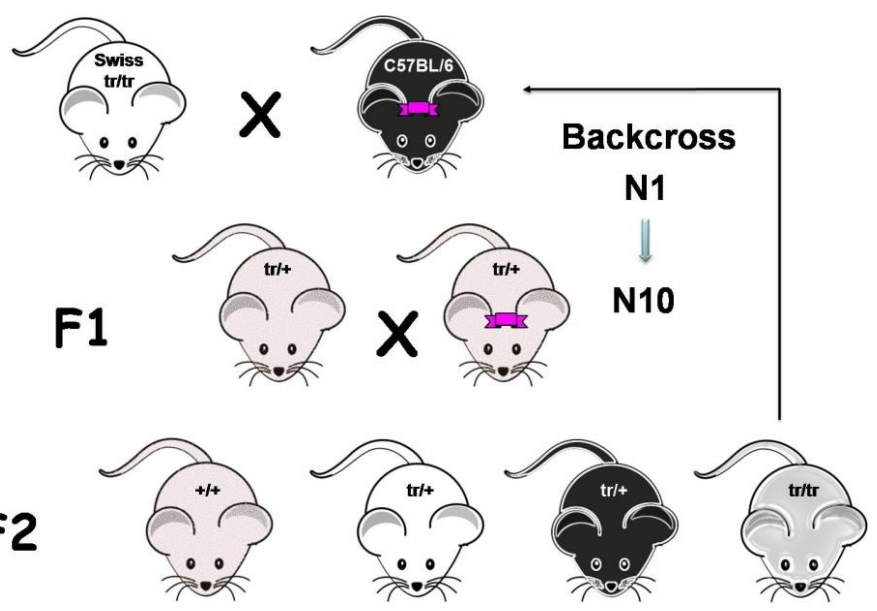

Fonte: (GARCIA-GOMES, 2016). 


\subsection{MATERIAL E MÉTODOS}

\subsubsection{Animais}

Os camundongos (Mus musculus) utilizados nos experimentos foram provenientes do Biotério do Departamento de Patologia da Faculdade de Medicina Veterinária e Zootecnia da Universidade de São Paulo (FMVZ-USP), de padrão sanitário convencional monitorizado. Os animais foram mantidos conforme descrito no item 3.2.1 do capítulo 1.

Os procedimentos experimentais foram submetidos e aprovados pela Comissão de Ética no Uso de Animais da FVMZ/USP e receberam número de protocolo 4124150116, aprovado no dia 23 de Março de 2016.

\subsubsection{Delineamento experimental}

O objetivo do trabalho foi caracterizar o fenótipo do camundongo mutante espontâneo tremor em fundo genético C57BL/6 em ambos os sexos. Para isso foram utilizados: 16 machos ( 8 controle e 8 mutantes) e 24 fêmeas (12 controles e 12 mutantes), com 8 semanas de idade no início dos experimentos. Realizou-se uma bateria de testes comportamentais para analisar os seguintes parâmetros: atividade geral em campo aberto, parâmetros comportamentais, ansiedade em labirinto em cruz elevada, coordenação motora em trave elevada, e respostas similares às de depressão no teste de natação forçada e suspensão pela cauda. A metodologia desses testes foi descrita no item 3.2.4 do capítulo 1 No presente estudo foi adicionado o teste de evocação de memória no labirinto em cruz elevada, realizado 24 horas após o teste de ansiedade no labirinto em cruz elevada - item 3.2.4.3 (capítulo 1). 


\subsubsection{Teste do Labirinto em Cruz Elevada para evocação da memória espacial}

Esse teste foi realizado em dois dias consecutivos, sendo que no primeiro dia analisou-se os dados dos 3 primeiros minutos do vídeo do teste de ansiedade no Labirinto em Cruz Elevada (item 3.2.4.3, capítulo 1). No segundo dia do teste os animais eram recolocados no labirinto por 3 minutos e os mesmos parâmetros foram medidos.

Os resultados do primeiro dia de teste servem para medir as respostas de ansiedade nos animais; já os resultados do segundo dia servem para analisar a memória espacial dos mesmos; uma vez que o animal já conhece o ambiente, devemos esperar menor frequência das respostas similares as de ansiedade. Esse teste foi proposto por Bernardi, M. M. (comunicação pessoal). Igualmente ao primeiro dia de teste, as sessões do segundo dia também foram filmadas para posterior análise com ajuda do mesmo software.

\subsubsection{Análise estatística}

Os dados foram analisados conforme descrito no item 3.3.5 do capítulo 1 . 


\subsection{RESULTADOS}

\subsubsection{Atividade geral em campo aberto}

A tabela 1 mostra a atividade geral de camundongos mutantes tremor machos e fêmeas em fundo genético C57BL/6 e seus respectivos grupos controle observada em campo aberto, e na figura 2 estão ilustrados os parâmetros que apresentaram variações significativas. No grupo dos machos o teste $\mathrm{t}$ de Student evidenciou redução significativa na frequência de levantar dos animais do grupo mutante em relação ao grupo controle ( $p=0,0003 ; t=4,962 ; d f=14$, figura $2 A$ ), e na frequência de grooming ( $p=0,0033 ; t=3,532 ; d f=14$, figura $2 C)$, mas não evidenciou diferenças nos outros parâmetros analisados; número de defecações $(p=0,1558 ; t=1,500 ; d f=14)$, número de poças de micção $(p=0,3343 ; t=1,000 ; d f=14)$, ou de tempo de locomoção $(p=0,3223 ; t=1,026 ; d f=14)$. Entretanto, no grupo das fêmeas o teste mostrou redução significante no número de poças de micção $(p=0,0243, t=2,419$, df=22,figura $2 E)$, na frequência de levantar $(p<0,0001, t=5,113 \mathrm{df}=22$, figura 2$)$ e no grooming $(p=0,0341, t=2,259, d f=22$, figura $2 D)$ dos animais do grupo mutante em relação ao grupo controle. Foi observada diminuição também da duração do tempo de locomoção das fêmeas mutantes em relação ao controle $(p=0,0418, t=2,162$, $d f=22$, figura $2 \mathrm{~F}$ ) mas, como no grupo dos machos, não foram observadas diferenças significativas na quantidade de defecações $(t=0,4193, d f=22, p=0,2096$, tabela 1$)$. 
Tabela 1 - Resultados dos parâmetros observados no teste de atividade geral em campo aberto dos camundongos C57BL/6 (controle) e C57BL/6 tremor, de ambos os sexos. Os dados foram representados em média e respectivos erro-padrão.

\begin{tabular}{lllllll}
\hline Parâmetros & $\begin{array}{l}\text { C57BL/6 } \sigma^{\top} \\
(\mathbf{n}=8)\end{array}$ & $\begin{array}{l}\text { tremorơ } \\
(\mathbf{n}=8)\end{array}$ & $\begin{array}{l}\text { Valor de } \\
\boldsymbol{p}\end{array}$ & $\begin{array}{l}\text { C57BL/6우 } \\
(\mathbf{n}=12)\end{array}$ & $\begin{array}{l}\text { tremor } \text { ㅇ } \\
(\mathbf{n}=12)\end{array}$ & Valor de $\boldsymbol{p}$ \\
\hline $\begin{array}{l}\text { Micção } \\
\text { (n. de poças) }\end{array}$ & $0,25 \pm 0,46$ & $0,5 \pm 0,53$ & 0,3343 & $0,083 \pm 0,29$ & $0,5 \pm 0,52$ & $0,0243^{*}$ \\
$\begin{array}{l}\text { Defecação } \\
\text { (n. cíbalas) }\end{array}$ & $1,5 \pm 1,93$ & $3 \pm 2,07$ & 0,1558 & $1,66 \pm 2,19$ & $2,42 \pm 2,27$ & 0,4193 \\
$\begin{array}{l}\text { Frequência de } \\
\text { Levantar }\end{array}$ & $23,87 \pm 10,38$ & $3,75 \pm 6,27$ & $0,0003^{* * *}$ & $58 \pm 22,65$ & $16,33 \pm 16,84$ & $<0,0001^{* * *}$ \\
$\begin{array}{l}\text { Frequência de } \\
\text { Grooming }\end{array}$ & $2,87 \pm 0,83$ & $1,12 \pm 1,12$ & $0,0033^{* *}$ & $4,25 \pm 1,66$ & $2,83 \pm 1,40$ & $0,0341^{*}$ \\
$\begin{array}{l}\text { Tempo de } \\
\text { Locomoção } \\
\text { (segundos) }\end{array}$ & $251,62 \pm 32,51$ & $265 \pm 17,40$ & 0,3223 & $\begin{array}{l}216,83 \pm \\
31,55\end{array}$ & $\begin{array}{l}244,92 \pm \\
32,09\end{array}$ & $0,0418^{*}$ \\
\hline
\end{tabular}

Fonte: (GARCIA-GOMES, 2017). 
Figura 2 - Resultados do teste de atividade geral em campo aberto realizado com os camundongos C57BL/6 (controle) e C57BL/6 tremor, de ambos os sexos. . Os dados são apresentados em média e respectivos erros-padrão. ${ }^{*} p<0,05$ em relação ao grupo controle, teste t de Student. A e B ${ }^{* * *} p=0,0003 ;$ C e D - ${ }^{* *} p=0,0033 ; E-{ }^{*} p=0,0243 ; F-{ }^{*} p=0,0418$.

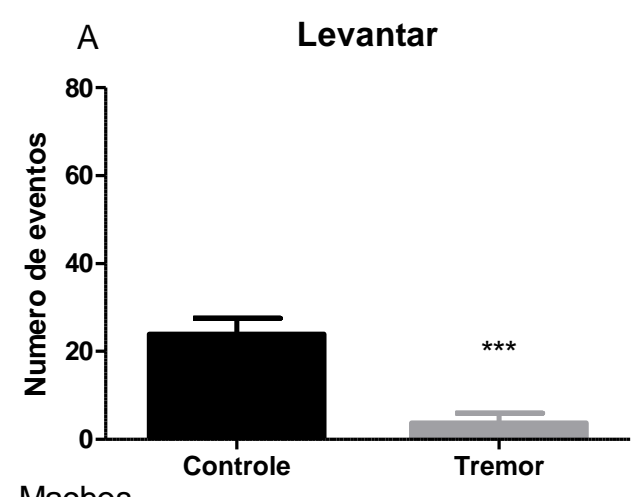

Machos
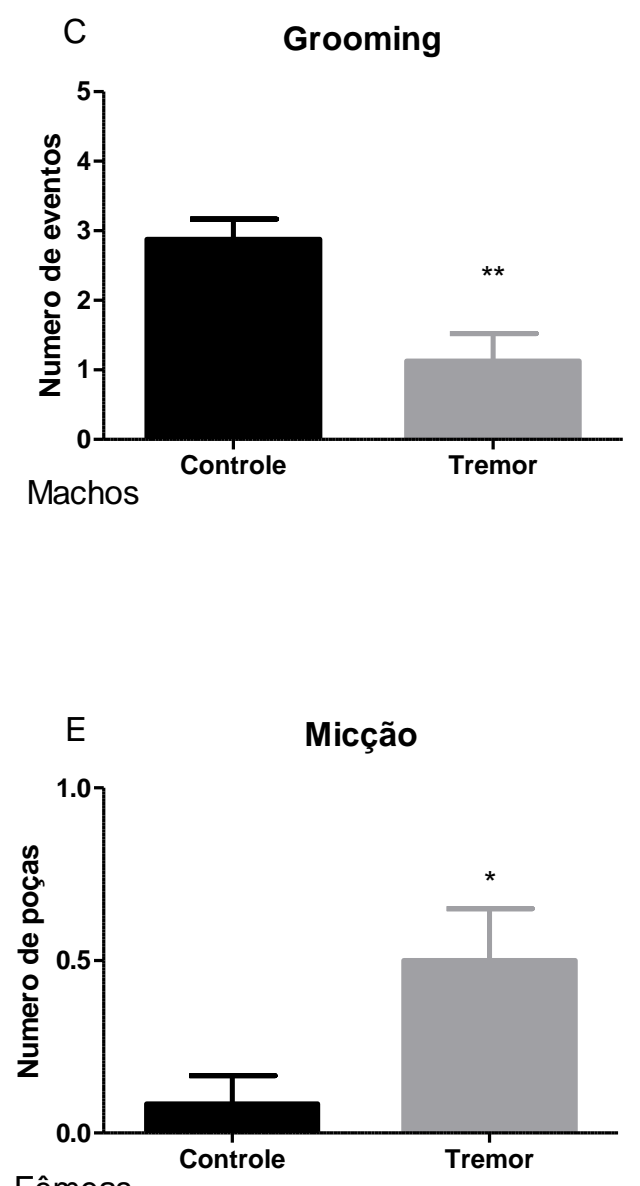

Fonte: (GARCIA-GOMES, 2017).

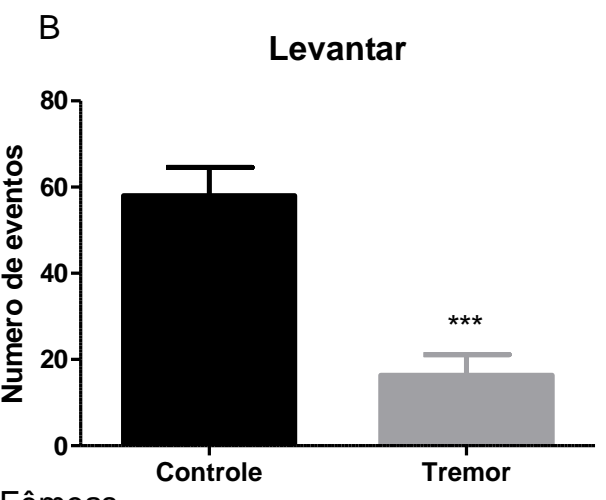

Fêmeas

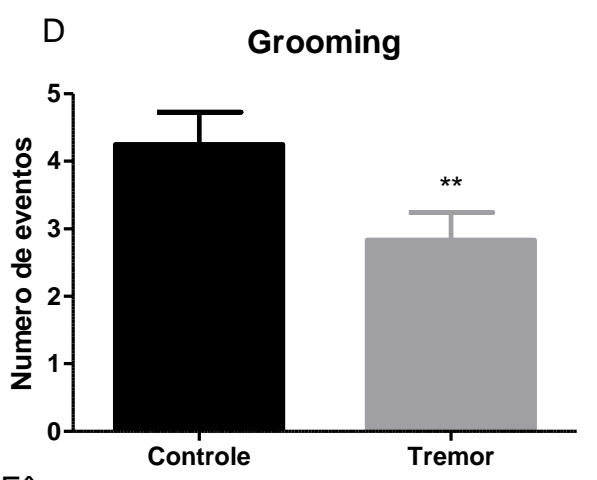

Fêmeas

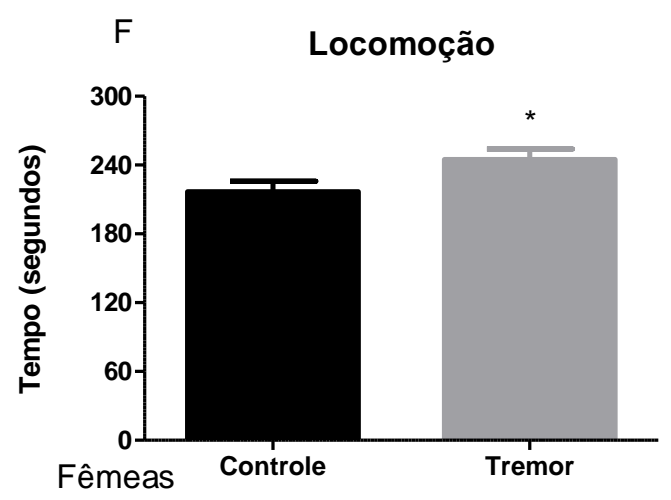




\subsubsection{Parâmetros Comportamentais}

A tabela 2 apresenta os resultados, em porcentagem por escore, dos parâmetros comportamentais que avaliam o sistema sensorial dos mutantes tremor em relação ao grupo controle. Os dados significativos estão representados na figura 3.

Tabela 2 - Resultados da avaliação do sistema sensorial de camundongos C57BL/6 (controle) e C57BL/6 tremor, de ambos os sexos. Os dados são apresentados em mediana (mínimo e máximo).

\begin{tabular}{|c|c|c|c|c|c|c|}
\hline Parâmetros & $\begin{array}{l}\text { C57BL/6 } \\
(n=8)\end{array}$ & $\begin{array}{l}\text { Tremoro } \\
(\mathrm{n}=8)\end{array}$ & Valor de $p$ & $\begin{array}{l}\text { C57BL/6우 } \\
(n=12)\end{array}$ & $\begin{array}{l}\text { tremor우 } \\
(n=12)\end{array}$ & Valor de $p$ \\
\hline Frêmito vocal & Não & Não & - & Não & Não & - \\
\hline Irritabilidade & $2(0-4)$ & $2(0-4)$ & 0,3485 & $0(0-4)$ & $0(0-4)$ & 0,1998 \\
\hline $\begin{array}{l}\text { Reflexo } \\
\text { Auricular }\end{array}$ & $1,5(0-4)$ & $0(0-4)$ & 0,2906 & $2,5(0-4)$ & $2(0-4)$ & 0,5491 \\
\hline $\begin{array}{l}\text { Aperto de } \\
\text { Cauda }\end{array}$ & $3,5(0-4)$ & $3(0-4)$ & 0,3974 & $4(0-4)$ & $4(0-4)$ & 0,4868 \\
\hline $\begin{array}{l}\text { Reflexo } \\
\text { Corneal }\end{array}$ & $3,5(0-4)$ & $3(0-4)$ & 0,3358 & $4(0-4)$ & $4(0-4)$ & 0,7446 \\
\hline $\begin{array}{l}\text { Resposta ao } \\
\text { Toque }\end{array}$ & $3,5(0-4)$ & $2(0-4)$ & 0,4761 & $3,5(0-4)$ & $2(0-4)$ & $0,0043^{* *}$ \\
\hline
\end{tabular}

Fonte: (GARCIA-GOMES, 2017).

No grupo das fêmeas foi observada uma diminuição no parâmetro de resposta ao toque dos animais mutantes em relação aos animais controles, a partir do teste de Mann-Witney ( $U=24,50, p=0,0043$, figura 3 ) os outros parâmetros não apresentaram diferenças significativas. 
Figura 3 - Resposta ao toque de camundongos C57BL/6 (controle) e C57BL/6 tremor fêmeas. Os dados são apresentados em média e respectivos erros-padrão.Teste $U$ de Mann -Witney. $N=$ 12/grupo. ${ }^{* *} \mathrm{p}=0,0043$.

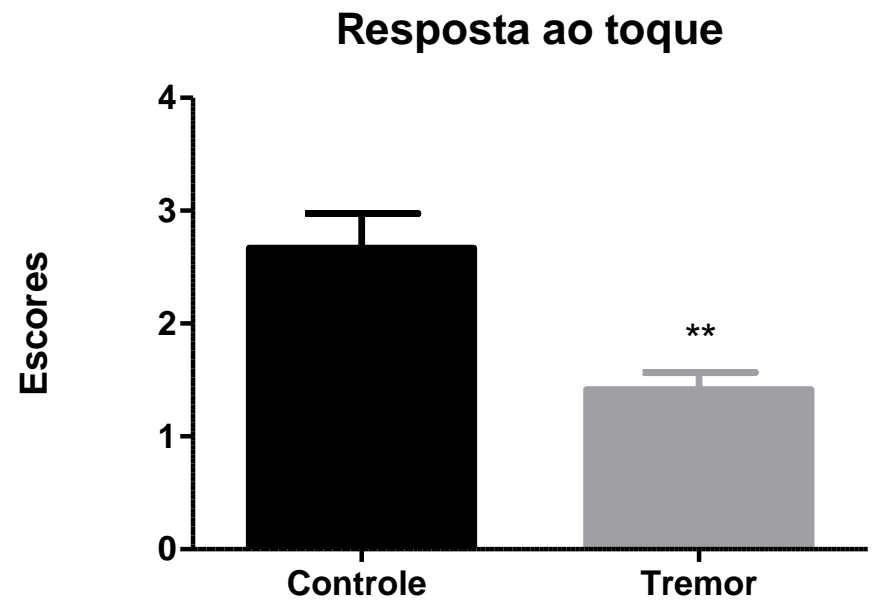

Fonte: (GARCIA-GOMES, 2017).

O quadro 1 apresenta os resultados dos testes psicomotores na avaliação de parâmetros comportamentais no campo aberto. Não foram observadas diferenças estatísticas significativas entre os grupos.

Quadro 1 - Resultados dos parâmetros psicomotores analisados em campo aberto, de camundongos C57BL/6 (controle) e C57BL/6 tremor, de ambos os sexos. Os dados são apresentados como presente ou ausente.

\begin{tabular}{|l|l|l|l|l|}
\hline Parâmetros & $\begin{array}{l}\text { C57BL/607 } \\
(\mathbf{n = 8})\end{array}$ & $\begin{array}{l}\text { tremoro' } \\
(\mathbf{n = 8})\end{array}$ & $\begin{array}{l}\text { C57BL/6 } \text { + } \\
(\mathbf{n = 1 2})\end{array}$ & $\begin{array}{l}\text { tremoro+ } \\
(\mathbf{n = 1 2})\end{array}$ \\
\hline Contorção & Não & Não & Não & Não \\
\hline Trem posterior & Não & Não & Não & Não \\
\hline Reflexo de endireitamento & Sim & Sim & Sim & Sim \\
\hline Tonus corporal & Sim & Sim & Sim & Sim \\
\hline Força de agarrar & Sim & Sim & Sim & Sim \\
\hline
\end{tabular}

Fonte: (GARCIA-GOMES, 2017).

A tabela 3 mostra que foram observadas diferenças estatísticas dos camundongos mutantes quando comparados aos controles, a partir do teste $U$ de Mann Witney, com aumento na ocorrência de tremores $(p<0,0001, U=0,0)$ em machos e fêmeas, presença de cauda em pé $(p=0,0033 ; U=8000$ dos machos, e $p<0,0001$ : $U=0,0$ das fêmeas) e de ataxia $(p<0,0001, U=0,0)$ dos machos e das fêmeas. 
Tabela 3 - Resultados dos parâmetros do sistema nervoso central analisados em campo aberto de camundongos C57BL/6 (controle) e C57BL/6 tremor, em ambos os sexos. Os dados são apresentados em mediana (mínimo e máximo), ou em presente/ausente.

\begin{tabular}{|c|c|c|c|c|c|c|}
\hline Parâmetros & $\begin{array}{l}\text { C57BL/6 } \\
(n=8)\end{array}$ & $\begin{array}{l}\text { Tremor o } \\
(\mathrm{n}=8)\end{array}$ & Valor de $p$ & $\begin{array}{l}\text { C57BL/6우 } \\
(n=12)\end{array}$ & $\begin{array}{l}\text { tremor } \text { 우 } \\
(n=12)\end{array}$ & Valor de $p$ \\
\hline Tremores & Não & Sim & $<0,0001^{* * *}$ & Não & Sim & $<0,0001^{* * *}$ \\
\hline Cauda em pé & $1(0-4)$ & $4(0-4)$ & $0,0033^{* *}$ & $0(0-4)$ & $4(0-4)$ & $<0,0001^{* * *}$ \\
\hline Ataxia & Não & Sim & $<0,0001^{* * *}$ & Não & Sim & $<0,0001^{* * *}$ \\
\hline
\end{tabular}

Fonte: (GARCIA-GOMES, 2017).

\subsubsection{Ansiedade no Labirinto em Cruz Elevada}

A tabela 4 mostra os resultados obtidos no teste de ansiedade na cruz elevada, dos camundongos machos. O teste $t$ de Student evidenciou diferenças significativas no número de entradas nos braços fechados (EBF); houve uma diminuição do numero de entradas dos mutantes tremor em relação aos controles $(p<0,0001 ; t=5,600 ; d f=16$, figura 4). Os demais parâmetros não apresentaram diferenças significativas. Número de entradas nos braços abertos (EBA; $p=0,3088$; $t=1,953 ; d f=16$ ), tempo nos braços fechados (TBF; $p=0,8585 ; t=0,1813 ; d f=16$ ), tempo nos braços abertos (TBA; $p=0,3507 ; t=0,9632 ; d f=16$ ), porcentagem de tempo nos braços aberto (\%TBA; $p=0,3507 ; t=0,9632 ; d f=16$ ), e porcentagem de entradas nos braços abertos (\%EBA; $p=0,3746 ; t=0,9152 ; d f=16$ ). Os dados significativos estão representados na figura 4 .

Tabela 4 - Resultados dos camundongos C57BL/6 (controle) e C57BL/6 tremor machos obtidos no teste de ansiedade no labirinto em cruz elevada. Dados apresentados em média e respectivos erropadrão.

\begin{tabular}{|c|c|c|}
\hline & C57BL/6 ठ $(\mathrm{N}=8)$ & Tremoro ${ }^{\top}(n=8)$ \\
\hline$\%$ TBA & $18 \pm 8,80$ & $24 \pm 16,54$ \\
\hline$\%$ EBA & $31 \pm 13,00$ & $37 \pm 15,61$ \\
\hline TBA & $54 \pm 26,40$ & $72 \pm 49,61$ \\
\hline TBF & $158 \pm 34,38$ & $154 \pm 53,97$ \\
\hline EBA & $8 \pm 4,93$ & $6 \pm 3,41$ \\
\hline EBF & $16 \pm 2,28$ & $9 \pm 2,67^{* * *}$ \\
\hline
\end{tabular}

Fonte: (GARCIA-GOMES, 2017). 
Figura 4: Resposta dos camundongos C57BL/6 (controle) e C57BL/6 tremor fêmeas no teste de Labirinto em cruz elevada para ansiedade. EBF- número de entradas no braço fechado. $\mathrm{N}=8$ /grupo. Os dados são apresentados em média e respectivos desvio-padrão. ${ }^{* * *} p<0,0001$.

\section{Entradas nos Braços Fechados}

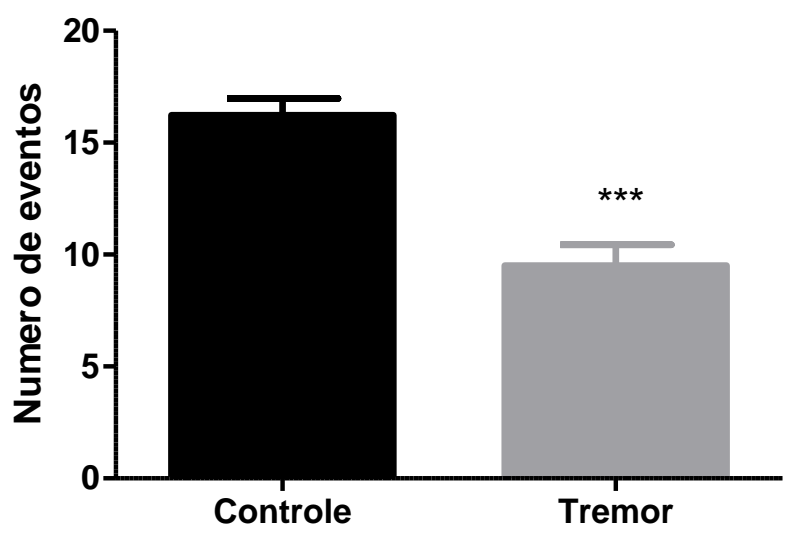

Fonte: (GARCIA-GOMES, 2017)

A tabela 5 ilustra as respostas de ansiedade no labirinto em cruz elevada dos camundongos C57BL/6 tremor fêmeas e seus respectivos controles, os resultados significativos também estão representados nas figuras 5 e 6 . $O$ teste t de Student mostrou redução tanto no número de entradas no braço aberto (EBA; $\mathrm{p}=0,0170$; $t=2,2603$, $d f=22$, figura $5 A$ ) como nos braços fechados (EBF; $p<0,0001 ; t=6,964$; $\mathrm{df}=22$, figura $5 \mathrm{~B}$ ) nos camundongos mutantes. Não foram observadas diferenças significativas entre $o$ tempo de permanência nos braços abertos (TBA; $p=0,0724 ; t=$ 1,$570 ; d f=11$ ) ou nos braços fechados (TBF; $p=0,1516 ; t=1,080 ; d f=11$ ). A tabela 5 mostra também que foram evidenciadas diferenças na porcentagem de entradas (\%EBA; $p<0,0001 ; t=4,675 ; d f=22$, figura $6 A$ ) e no tempo de permanência (\%TBA; $p=0,0410 ; t=1,822 ; d f=22$, figura $6 B$ ) nos braços abertos.

Tabela 5 - Resultados dos camundongos fêmeas C57BL/6 (controle) e C57BL/6 tremor no teste de ansiedade em labirinto em cruz elevada. Apresentados em média e respectivos erro-padrão.

\begin{tabular}{lll}
\hline & C57BL/6 o $(\mathrm{N}=12)$ & Tremor ㅇ $(\mathrm{n}=\mathbf{1 2})$ \\
\hline \% TBA & $43 \pm 20,41$ & $53 \pm 15,01^{*}$ \\
$\%$ EBA & $34 \pm 10,55$ & $67 \pm 18,97^{* * *}$ \\
TBA & $93 \pm 58,24$ & $134 \pm 47,83$ \\
TBF & $111 \pm 31,55$ & $109,5 \pm 34,97$ \\
EBA & $14 \pm 6,42$ & $9 \pm 2,35^{*}$ \\
EBF & $16 \pm 4,27$ & $6 \pm 2,85^{* * *}$ \\
\hline
\end{tabular}

Fonte: (GARCIA-GOMES, 2017). 
Figura 5 - Resposta dos camundongos fêmeas C57BL/6 (controle) e C57BL/6 tremor no teste de Labirinto em Cruz Elevada. $\mathrm{N}=12 / \mathrm{grupo}$. Os dados são apresentados em média e respectivos desviopadrão. A - ${ }^{*} p=0,0170 ; B-{ }^{* * *} p<0,0001$.
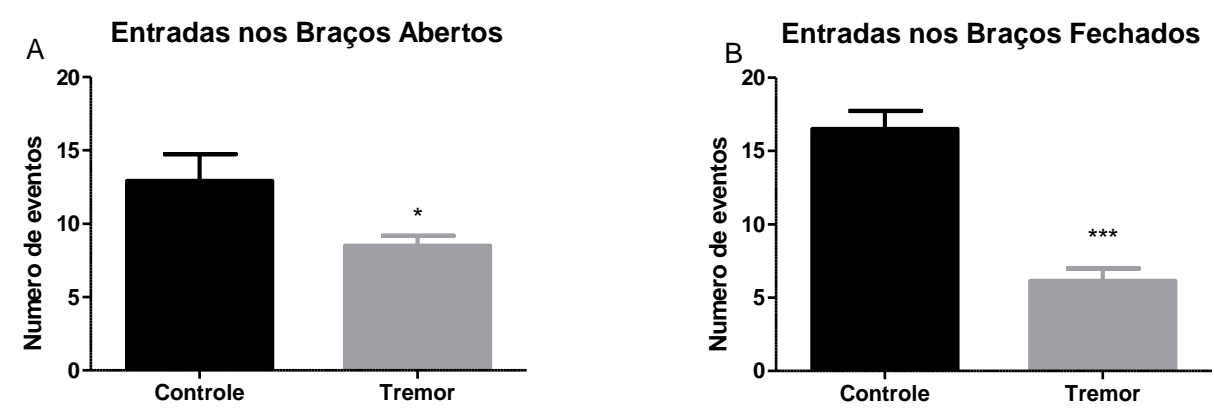

Fonte: (GARCIA-GOMES, 2017).

Figura 6: Resposta dos camundongos fêmeas C57BL/6 (controle) e C57BL/6 tremor no teste de Labirinto em Cruz Elevada. \%TBA - porcentagem de tempo nos braços abertos; \%EBA porcentagem do número de entradas nos braços abertos. $N=12$ grupo. Os dados são apresentados em média e respectivos desvio-padrão. $A-{ }^{*} p=0,0410 ; B$ - ${ }^{* * *} p<0,0001$.
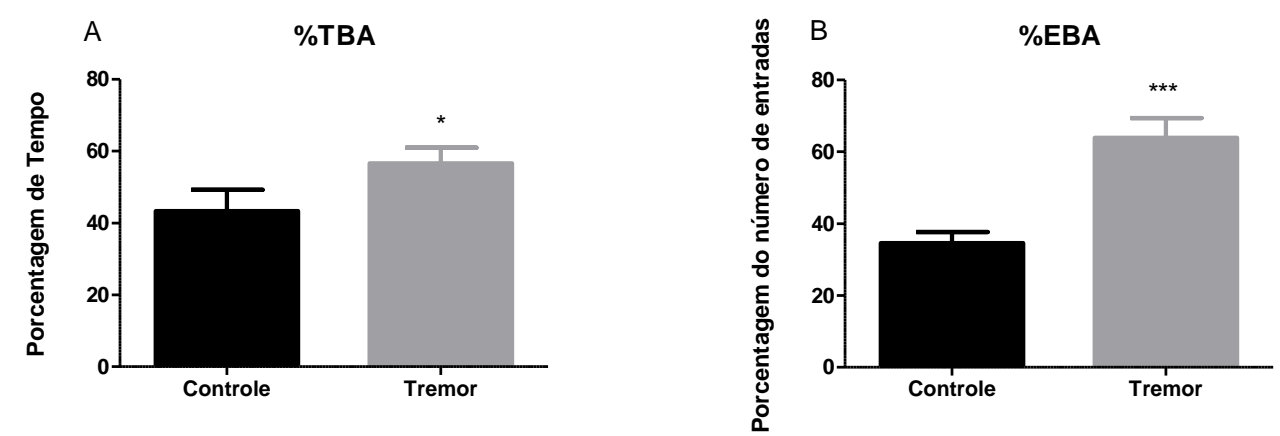

Fonte: (GARCIA-GOMES, 2017).

\subsubsection{Evocação de memória espacial no Labirinto em Cruz Elevada}

A tabela 6 mostra os resultados obtidos no teste de memória espacial em labirinto em cruz elevada dos camundongos C57BL/6 tremor machos e seus controles. Na comparação entre a resposta dos animais no primeiro e segundo dia do experimento, o teste $t$ de Student evidenciou diferenças significativas em todos os parâmetros, exceto no número de entradas nos braços fechados do grupo tremor $(E B F)(p=0,3662 ; t=0,9661 ; d f=8)$. O grupo controle apresentou diferenças no tempo de permanência nos braços abertos (TBA) $(p=0,0025 ; t=4,344 ; d f=8$, figura $8 A)$, nos braços fechados (TBF) $(p=0,0002 ; t=6,304 ; d f=8$, figura $8 C)$; no número de entradas 
nos braços fechados (EBF) $(p=0,0008 ; t=5,250 ; d f=8$, figura $9 C)$, nos braços abertos (EBA) $(p=0,0003 ; t=5,970 ; d f=8$, figura 9A); na porcentagem de tempo nos braços abertos (\%TBA) $(p=0,0025 ; t=4,344 ; d f=8$, figura $7 C)$ e na porcentagem de entradas nos braços abertos (\%EBA) $(p=0,0003 ; t=5,970 ; d f=8$, figura $7 A)$. Já o grupo tremor apresentou diferenças também no tempo de permanência nos braços abertos (TBA) $(p=0,0113 ; t=3,410 ; d f=8$, figura $8 B)$, nos braços fechados $(T B F)(p=0,0099$; $t=3,511$; $d f=8$, figura $8 D$ ), no número de entradas nos braços abertos $(E B A)(p=0,0036 ; t=4,296 ; d f=8$, figura $9 A)$, na porcentagem de tempo nos braços abertos $(\%$ TBA $)(p=0,0113 ; t=3,410 ; d f=8$, figura 7D) e na porcentagem de entradas nos braços abertos $(\% E B A)(p=0,0036 ; t=4,296 ; d f=8$, figura $7 B)$. Os resultados significantes estão apresentados nas figuras 7, 8 e 9.

Tabela 6 - Comparação dos resultados do teste de memória espacial em labirinto em cruz elevada em camundongos machos C57BL/6 (controle) e C57BL/6 tremor. Os valores foram apresentados em média e respectivos erro-padrão.

\begin{tabular}{lll}
\hline & C57BL $/ 6 \sigma^{7} \times$ C57BL $/ 6 \sigma^{\top}($ Teste) $(\mathrm{N}=8)$ & Tremor $\sigma^{\top} \times$ Tremor $\sigma^{\top}$ (Teste) $(\mathrm{N}=8)$ \\
\hline \%EBA & $\mathrm{p}=0,0003^{* * *}, \mathrm{t}=5,970, \mathrm{df}=8$ & $\mathrm{p}=0,0036^{* *}, \mathrm{t}=4,296, \mathrm{df}=8$ \\
\%TBA & $\mathrm{p}=0,0025^{* *}, \mathrm{t}=4,344, \mathrm{df}=8$ & $\mathrm{p}=0,0113^{*}, \mathrm{t}=3,410, \mathrm{df}=8$ \\
EBA & $\mathrm{p}=0,0003^{* * *}, \mathrm{t}=5,970, \mathrm{df}=8$ & $\mathrm{p}=0,0036^{* *}, \mathrm{t}=4,296, \mathrm{df}=8$ \\
EBF & $\mathrm{p}=0,0008^{* * *}, \mathrm{t}=5,250, \mathrm{df}=8$ & $\mathrm{p}=0,3662, \mathrm{t}=0,9661, \mathrm{df}=8$ \\
TBA & $\mathrm{p}=0,0025^{* *}, \mathrm{t}=4,344, \mathrm{df}=8$ & $\mathrm{p}=0,0113^{*}, \mathrm{t}=3,410, \mathrm{df}=8$ \\
TBF & $\mathrm{p}=0,0002^{* * *}, \mathrm{t}=6,304, \mathrm{df}=8$ & $\mathrm{p}=0,0099^{* *}, \mathrm{t}=3,511, \mathrm{df}=8$ \\
\hline
\end{tabular}

Fonte: (GARCIA-GOMES, 2017) 
Figura 7 - Resultados dos camundongos machos C57BL/6 (controle) e C57BL/6 tremor no teste no labirinto em cruz elevada para evocação de memória espacial. \%EBA - Porcentagem de Entradas nos braços abertos, \%TBA - porcentagem de tempo nos braços abertos. $\mathrm{N}=9 /$ grupo. Resultados apresentados em média e respectivos erro-padrão. A - ${ }^{* *} p=0,0014 ; B-{ }^{* *} p=0,0036 ; C$ - ${ }^{* *} p=0,0025 ; D$ $-{ }^{*} \mathrm{p}=0,0113$.
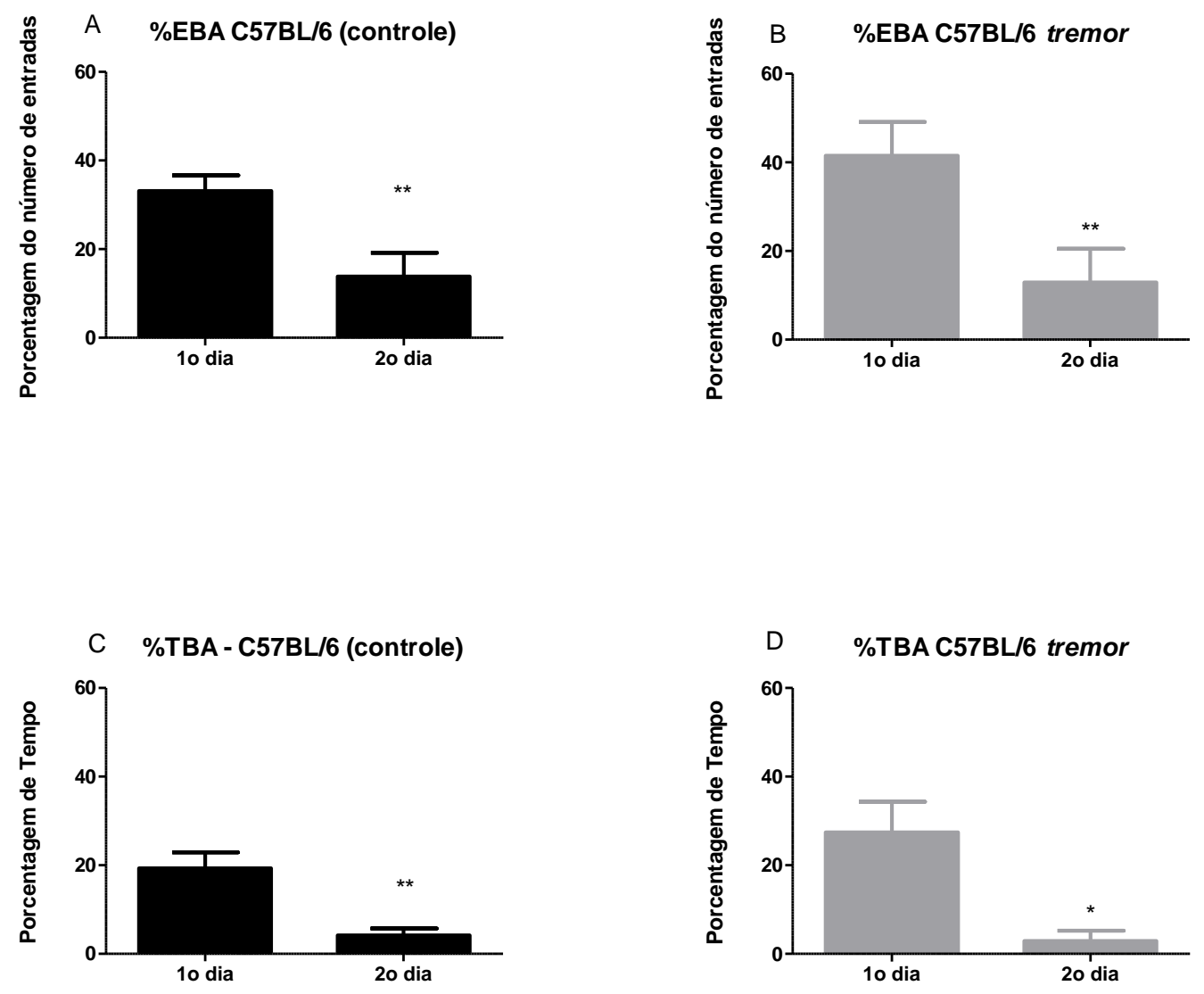

Fonte: (GARCIA-GOMES, 2017). 
Figura 8 - Resultados dos camundongos machos C57BL/6 (controle) e C57BL/6 tremor no teste no labirinto em cruz elevada para evocação de memória espacial. EBA - número de entradas nos braços abertos, EBF - número de entradas nos braços fechados. N=9/grupo. Resultados apresentados em média e respectivos erro-padrão. $A-{ }^{* * *} p=0,0003 ; B-{ }^{* *} p=0,0036 ; C-{ }^{* * *} p=0,0008$.
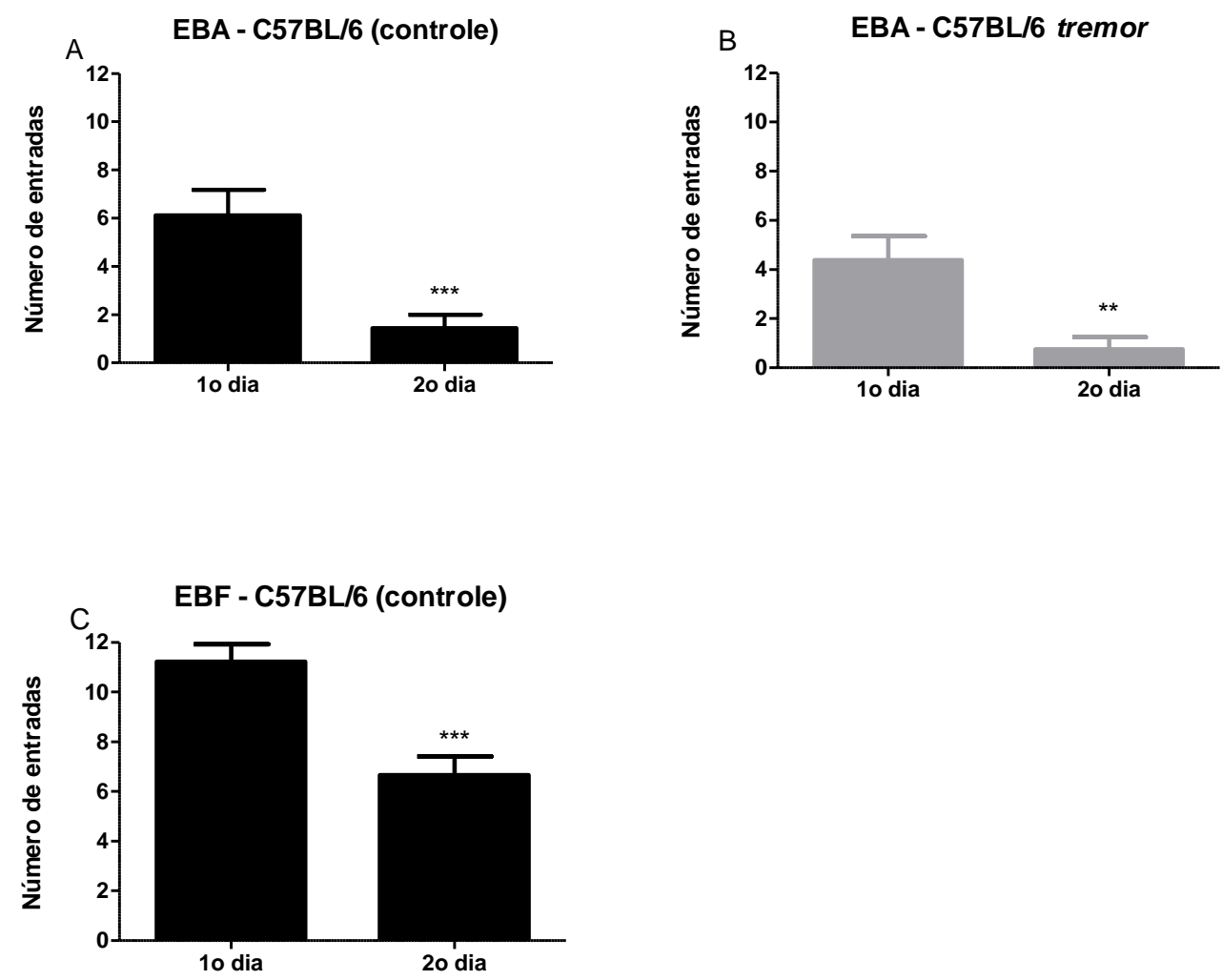

Fonte: (GARCIA-GOMES, 2017). 
Figura 9 - Resultados dos camundongos machos C57BL/6 (controle) e C57BL/6 tremor no teste no labirinto em cruz elevada para evocação de memória espacial. TBA - tempo nos braços abertos, TBF - tempo nos braços fechados. $\mathrm{N}=9 /$ grupo. Resultados apresentados em média e respectivos erropadrão. A - ${ }^{* \star} p=0,0025 ; B-{ }^{*} p=0,0113 ; C-{ }^{* *} p=0,0002 ; D-{ }^{* *} p=0,0099$.
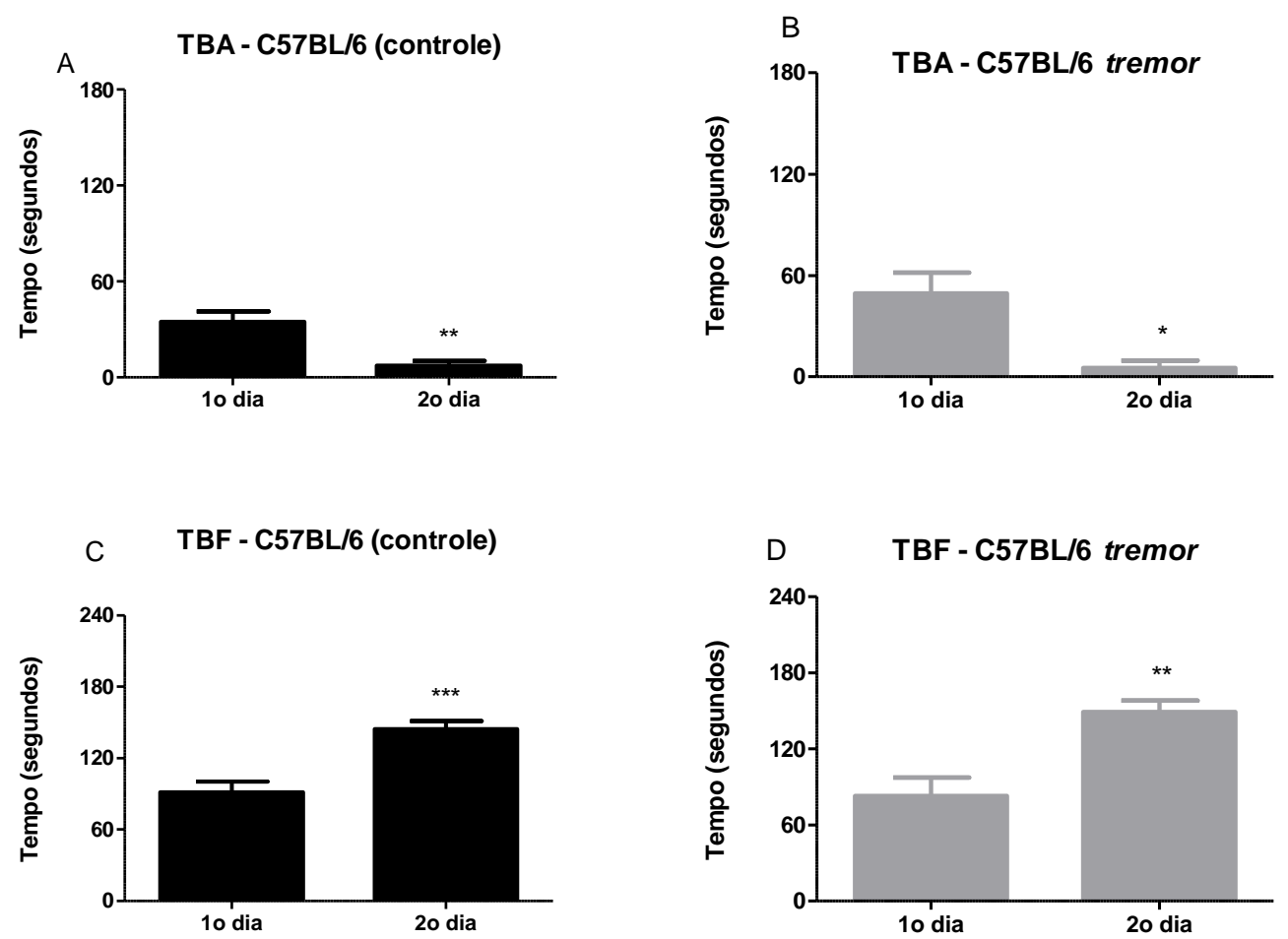

Fonte: (GARCIA-GOMES, 2017).

Não foram observadas diferenças no número de entradas nos braços fechados (EBF) no grupo controle ( $\mathrm{p}=0,2690 ; \mathrm{t}=1,164$; $\mathrm{df}=11$, tabela 7 ) ou no grupo tremor $(p=0,4063 ; t=0,8636 ; d f=11$, tabela 7$)$. Nos dois grupos foram observadas diminuições nas porcentagens do número de entradas nos braços abertos (\%EBA) controle $(p=0,0103 ; t=3,091 ; d f=11$, figura $10 A)$, tremor $(p=0,0415 ; t=4,534 ; d f=11$, figura 10B) e na porcentagem de tempo nos braços abertos (\%TBA) controle $(p=0,0009 ; t=4,534 ; d f=11$ figura $10 C)$, tremor $(p=0,0127 ; t=2,972 ; d f=11$, figura 10D) do primeiro dia em relação ao segundo.

A tabela 7 ilustra as respostas dos camundongos mutantes tremor fêmeas em fundo genético C57BL/6 e seus respectivos controles no teste do labirinto em cruz elevada para memória espacial analisadas a partir do teste t de Student, e as figuras 10 e 11 mostra os que apresentaram diferenças significativas. Na comparação entre a resposta dos animais no primeiro e segundo dia do experimento, o teste $t$ de Student evidencia diminuição do número de entradas nos braços abertos dos dois 
grupos (EBA), controle $(p=0,0009 ; t=4,520 ; d f=11$, figura 11A) e tremor $(p=0,00012$; $t=4,308$; $d f=11$, figura 11B), e no tempo de permanência nos braços abertos (TBA) também dos dois grupos - controle $(p=0,0023 ; t=3,933 ; d f=11$, figura $11 \mathrm{C})$ e tremor $(p=0,0139 ; t=2,921 ; d f=11$, figura $11 D)$, e aumento no tempo de permanência dos dois grupos nos braços fechados $(T B F)$ : controle $(p<0,0001 ; t=6,273$; $d f=11$, figura $11 \mathrm{E})$ e tremor $(\mathrm{p}=0,0050 ; \mathrm{t}=3,497 ; \mathrm{df}=11$, figura $11 \mathrm{~F})$.

Tabela 7: Resultados dos camundongos fêmeas C57BL/6 (controle) e C57BL/6 tremor observados no teste de labirinto em cruz elevada para evocação da memória espacial. Os valores foram apresentados em média e respectivos erro-padrão. $\mathrm{N}=12$ /grupo.

\begin{tabular}{lll}
\hline & $\begin{array}{l}\text { C57BL/6 우 } \times \text { C57BL/6 우 (Teste) } \\
(\mathrm{N}=\mathbf{1 2})\end{array}$ & $\begin{array}{l}\text { Tremor 우 } \times \text { Tremor } \text { ㅇ (Teste) } \\
(\mathrm{N}=\mathbf{1 2})\end{array}$ \\
\hline \%EBA & $\mathrm{p}=0,0103^{*}, \mathrm{t}=3,091, \mathrm{df}=11$ & $\mathrm{p}=0,0415^{*}, \mathrm{t}=2,308, \mathrm{df}=11$ \\
\%TBA & $\mathrm{p}=0,0009^{* * *}, \mathrm{t}=4,534, \mathrm{df}=11$ & $\mathrm{p}=0,0127^{*}, \mathrm{t}=2,972, \mathrm{df}=11$ \\
EBA & $\mathrm{p}=0,0009^{* * *}, \mathrm{t}=4,520, \mathrm{df}=11$ & $\mathrm{p}=0,0012^{* *}, \mathrm{t}=4,308, \mathrm{df}=11$ \\
EBF & $\mathrm{p}=0,2690, \mathrm{t}=1,164, \mathrm{df}=11$ & $\mathrm{p}=0,4063, \mathrm{t}=0,863, \mathrm{df}=11$ \\
TBA & $\mathrm{p}=0,0023^{* *}, \mathrm{t}=3,933, \mathrm{df}=11$ & $\mathrm{p}=0,0139^{*}, \mathrm{t}=2,921, \mathrm{df}=11$ \\
TBF & $\mathrm{p}<0,0001^{* * *}, \mathrm{t}=6,273, \mathrm{df}=11$ & $\mathrm{p}=0,0050^{* *}, \mathrm{t}=3,497, \mathrm{df}=11$ \\
\hline
\end{tabular}

Fonte: (GARCIA-GOMES, 2017). 
Figura 10 - Resultados dos camundongos fêmeas C57BL/6 (controle) e C57BL/6 tremor no teste no labirinto em cruz elevada para evocação de memória espacial. \%EBA - Porcentagem de Entradas nos braços abertos, \%TBA -porcentagem de tempo nos braços abertos. $\mathrm{N}=12 /$ grupo. Resultados apresentados em média e respectivos erro-padrão. $A-{ }^{* *} p=0,0051 ; B-{ }^{*} p=0,0207 ; C$ - ${ }^{* *} p=0,0004$; D $-{ }^{* *} \mathrm{p}=0,0063$.
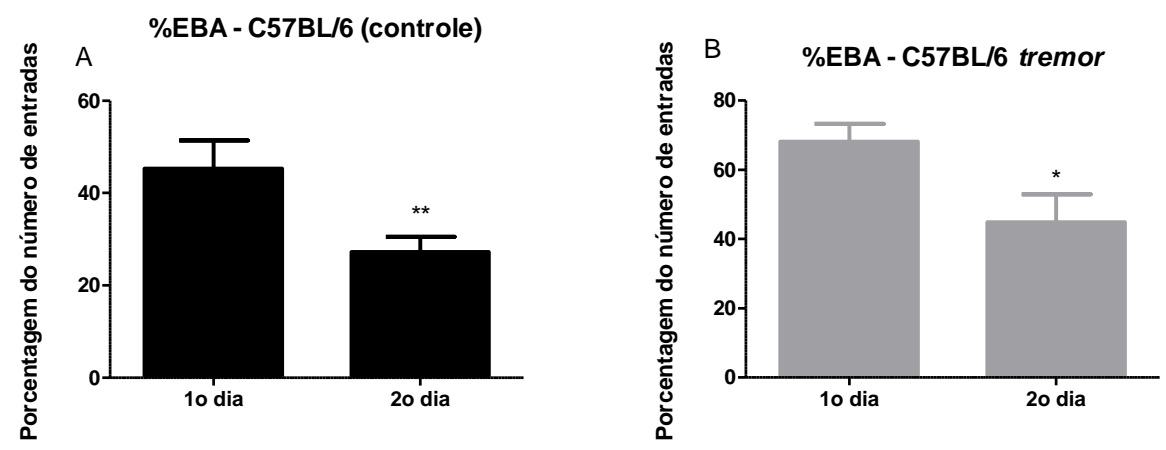

C \%TBA - C57BL/6 (controle)

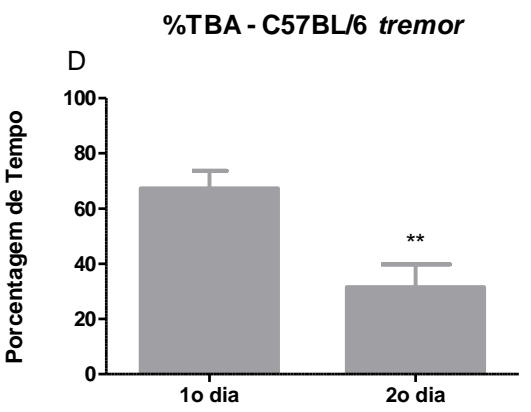

Fonte: (GARCIA-GOMES, 2017). 
Figura 11 - Resultados dos camundongos fêmeas C57BL/6 (controle) e C57BL/6 tremor no teste no labirinto em cruz elevada para evocação de memória espacial. EBA - Entradas nos braços abertos), TBA - tempo nos braços abertos), TBF - tempo nos braços fechados. $\mathrm{N}=12 /$ grupo. Resultados apresentados em média e respectivos erro-padrão. A - ${ }^{* * *} \mathrm{p}=0,0004 ; \mathrm{B}-{ }^{* * *} \mathrm{p}=0,0006 ; \mathrm{C}-{ }^{* *} \mathrm{p}=0,0012$; $D-{ }^{* *} p=0,0070 ; E-{ }^{* *} p=0,0025 ; F-{ }^{* * *} p<0,0001$.
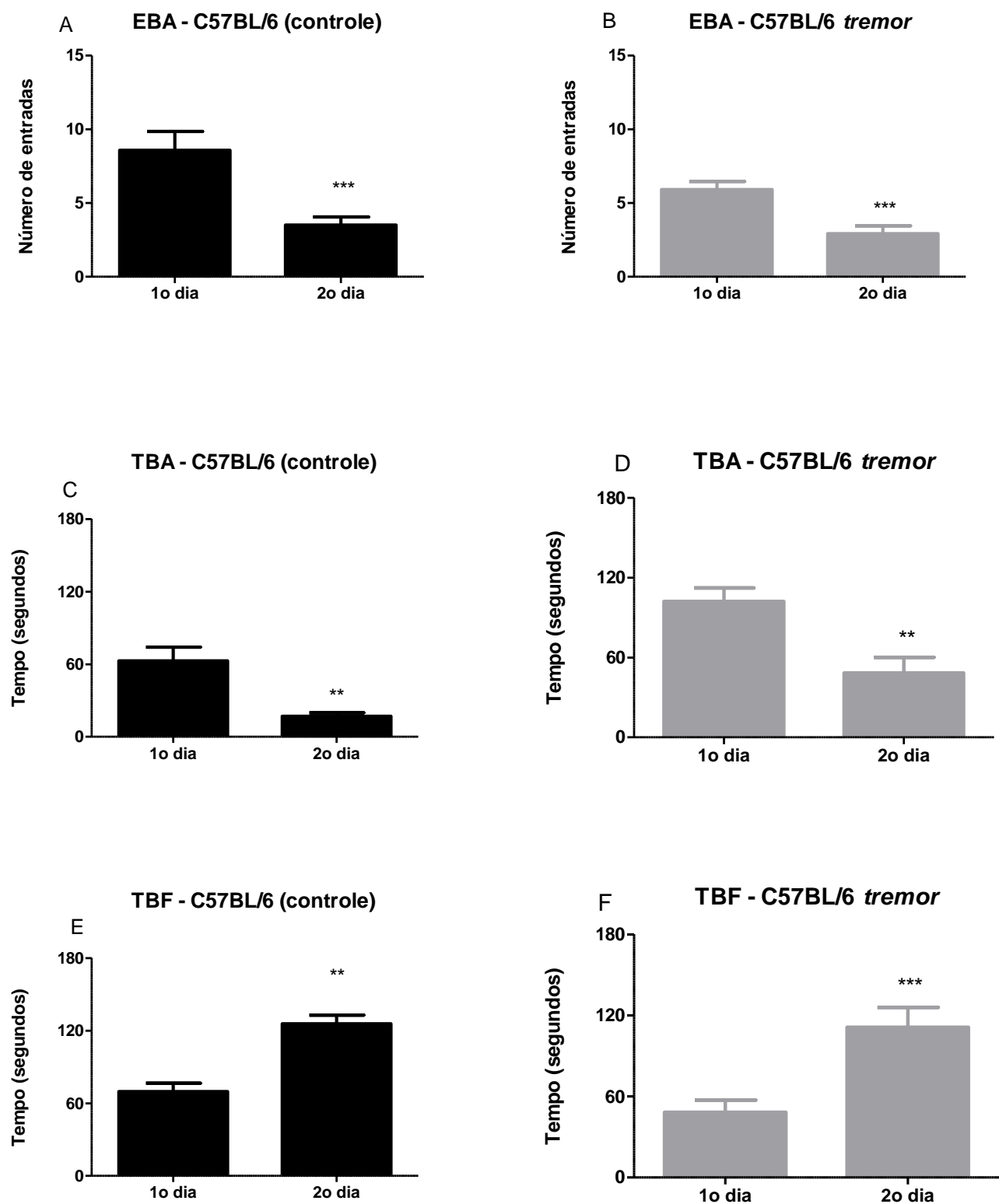

Fonte: (GARCIA-GOMES, 2017). 


\subsubsection{Coordenação Motora em Trave elevada}

A figura 12 ilustra as respostas dos mutantes tremor machos e fêmeas em fundo genético C57BL/6 e o respectivo grupo controle no comportamento da trave elevada. $O$ teste $U$ de Mann-Witney indicou redução significante nos escores da trave elevada dos animais mutantes em relação ao grupo controle $(p<0,0001)$.

Figura 12 - Respostas dos camundongos machos (A) e fêmeas (B) C57BL/6 (controle) e C57BL/6 tremor no teste de coordenação motora em trave elevada. São apresentadas as distribuições dos dois grupos. ${ }^{* * *} p<0,0001$, em relação ao grupo controle (teste $U$ de Mann-Witney). Machos: $n=$ 8/grupo, fêmeas: $n=12 /$ grupo.
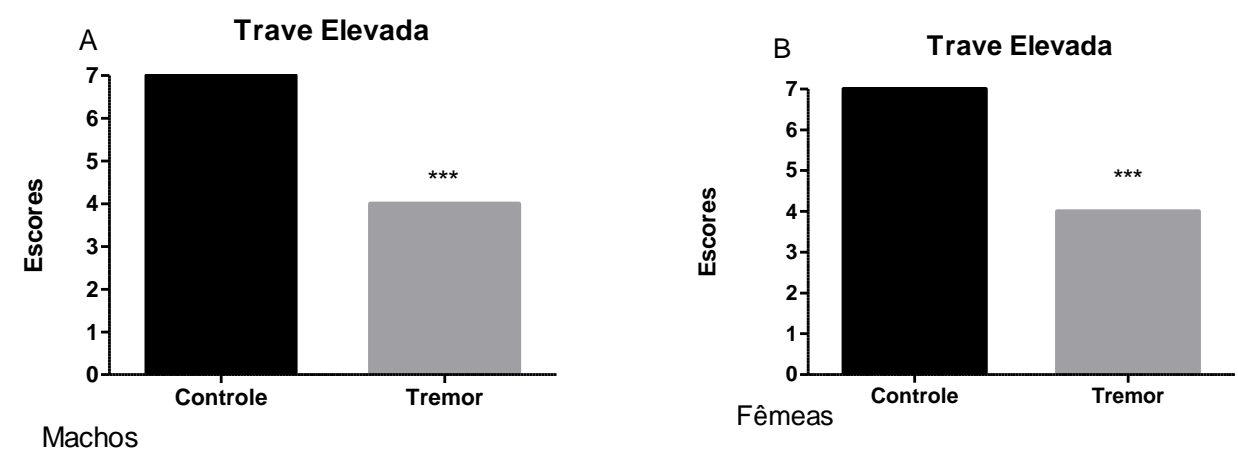

Fonte: (GARCIA-GOMES, 2017).

A figura 13 ilustra a postura dos camundongos atravessando a trave elevada. $\mathrm{Na}$ figura 13A observa-se o camundongo C57BL/6 andando sem dificuldade, com postura normal e apoiando as quatro patas na trave; enquanto na figura 13B observa-se o camundongo mutante tremor andando com dificuldade e alteração de postura, apresentando o trem posterior abaixado, a cauda enrolada na trave e o focinho apoiado. 
Figura 13 - camundongo C57BL/6 no teste de coordenação motora em trave elevada. A) camundongo controle $\mathrm{C} 57 \mathrm{BL} / 6$ andando na trave; B) camundongo tremor andando na trave.

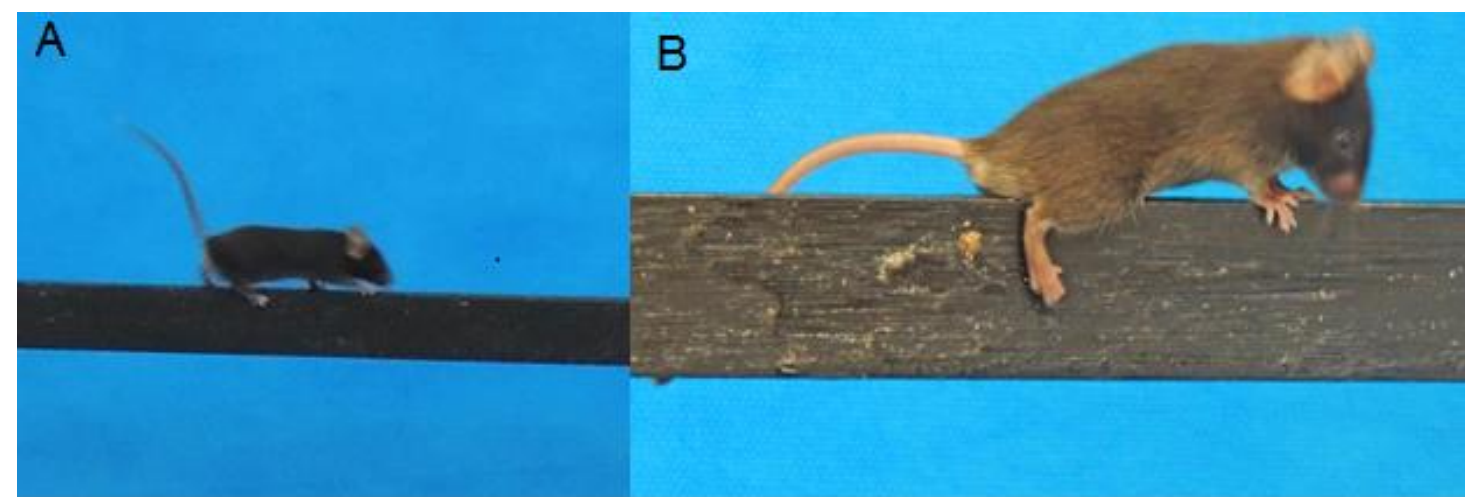

Fonte: (GARCIA-GOMES, 2017).

\subsubsection{Memória em Labirinto em T}

A figura 14 ilustra o comportamento de camundongos mutantes tremor machos e fêmeas em fundo genético C57BL/6 e seus controles no teste de alternância espontânea em Labirinto em T. O teste $U$ de Mann-Witney não indicou diferenças significativas entre as respostas dos animais mutantes e do grupo controle $(p=0,9549 ; U=31,00$ para os machos e $p=0,6225 ; U=63,50$ para as fêmeas).

Figura 14 - Comportamento de camundongos C57BL/6 (controle) e C57BL/6 tremor de ambos os sexos no teste de alternância espontânea em Labirinto em T. Os dados são apresentados em média e respectivos erros-padrão. Teste $U$ de Mann-Witney.
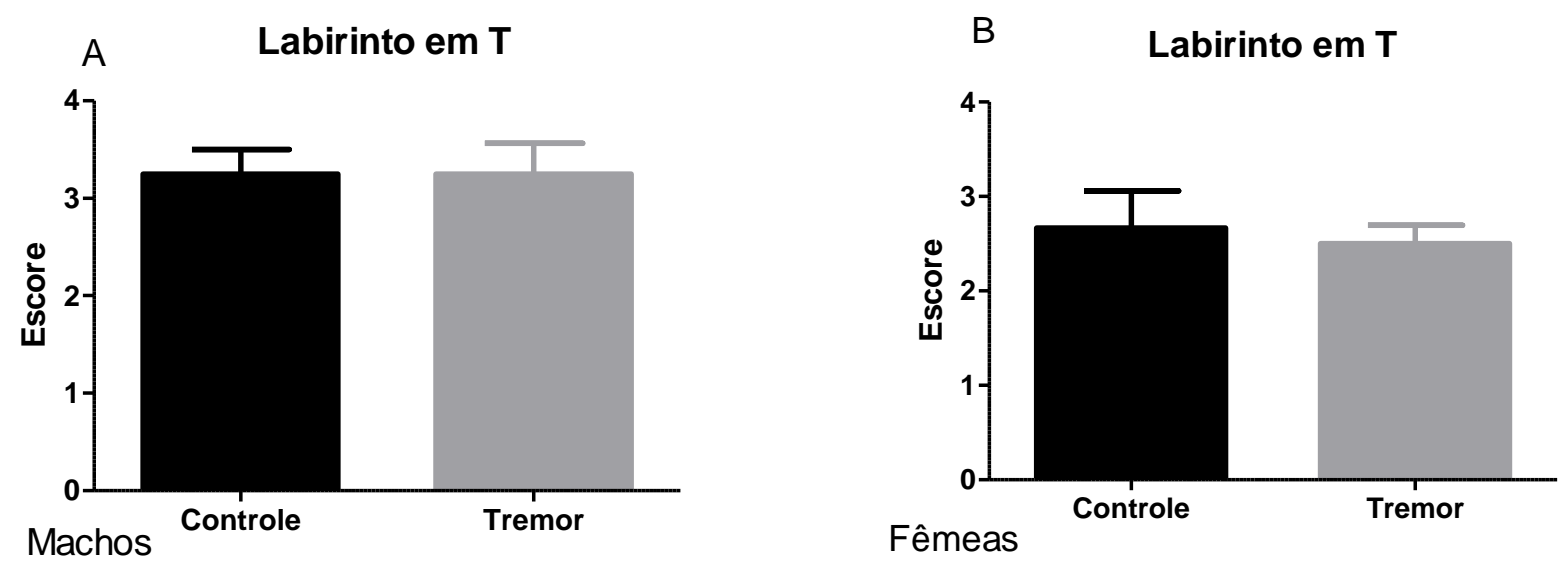

Fonte: (GARCIA-GOMES, 2017). 


\subsubsection{Natação Forçada}

A tabela 8 mostra as respostas similares às de depressão dos camundongos machos e fêmeas mutantes tremor em fundo genético C57BL/6 e o respectivo grupo controle no teste de natação forçada. O teste $t$ de Student evidenciou diferenças significativas (figura 15) no tempo de imobilidade total para o grupo dos machos $(p<0,0001 ; t=6,892 ; d f=22$, figura $15 A)$, mas não no tempo de latência para a primeira imobilidade $(p=0,0949 ; t=1,827 ; d f=22)$. Já no grupo das fêmeas foram observadas diferenças significativas no tempo de imobilidade total $(p<0,0001$; $t=5.032$; $d f=22$, figura $15 \mathrm{~B}$ ) e no tempo de latência para a primeira imobilidade $(p=0,0015 ; t=3,613 ; d f=22$, figura $15 C)$.

Tabela 8 - Respostas no teste de natação forçada de camundongos C57BL/6 (controle) e C57BL/6 tremor de ambos os sexos. Os dados são apresentados em mediana (mínimo e máximo).

\begin{tabular}{|c|c|c|c|c|c|c|}
\hline Parâmetros & $\begin{array}{l}\text { C57BL/6o' } \\
(n=8)\end{array}$ & $\begin{array}{l}\text { tremor }{ }^{\top} \\
(\mathrm{n}=8)\end{array}$ & Valor de $p$ & $\begin{array}{l}\text { C57BL/6우 } \\
(n=12)\end{array}$ & $\begin{array}{l}\text { tremor우 } \\
(\mathrm{n}=12)\end{array}$ & Valor de $p$ \\
\hline $\begin{array}{l}\text { Latência } \\
\text { para a 1a } \\
\text { imobilidade } \\
\text { (segundos) }\end{array}$ & $8,14 \pm 5,70$ & $3,83 \pm 0,75$ & 0,0949 & $56,25 \pm 71,02$ & $246,5 \pm 168$ & $0,0015^{* *}$ \\
\hline $\begin{array}{l}\text { Tempo total } \\
\text { de } \\
\text { imobilidade }\end{array}$ & $111 \pm 39,48$ & $5,43 \pm 9,14$ & $<0,0001^{* * *}$ & $78,5 \pm 46,32$ & $7,58 \pm 15,40$ & $<0,0001^{* * *}$ \\
\hline
\end{tabular}


Figura 15 - Comportamento de camundongos C57BL/6 (controle) e C57BL/6 tremor de ambos os sexos no teste de natação forçada. Os dados são apresentados em média e respectivos errospadrão. Teste T de Student. Machos: $n=8 /$ grupo, fêmeas: $n=12 /$ grupo. A e $B \quad{ }^{* \star *}<0,0001$; C ${ }^{* *} \mathrm{p}=0,0015$.
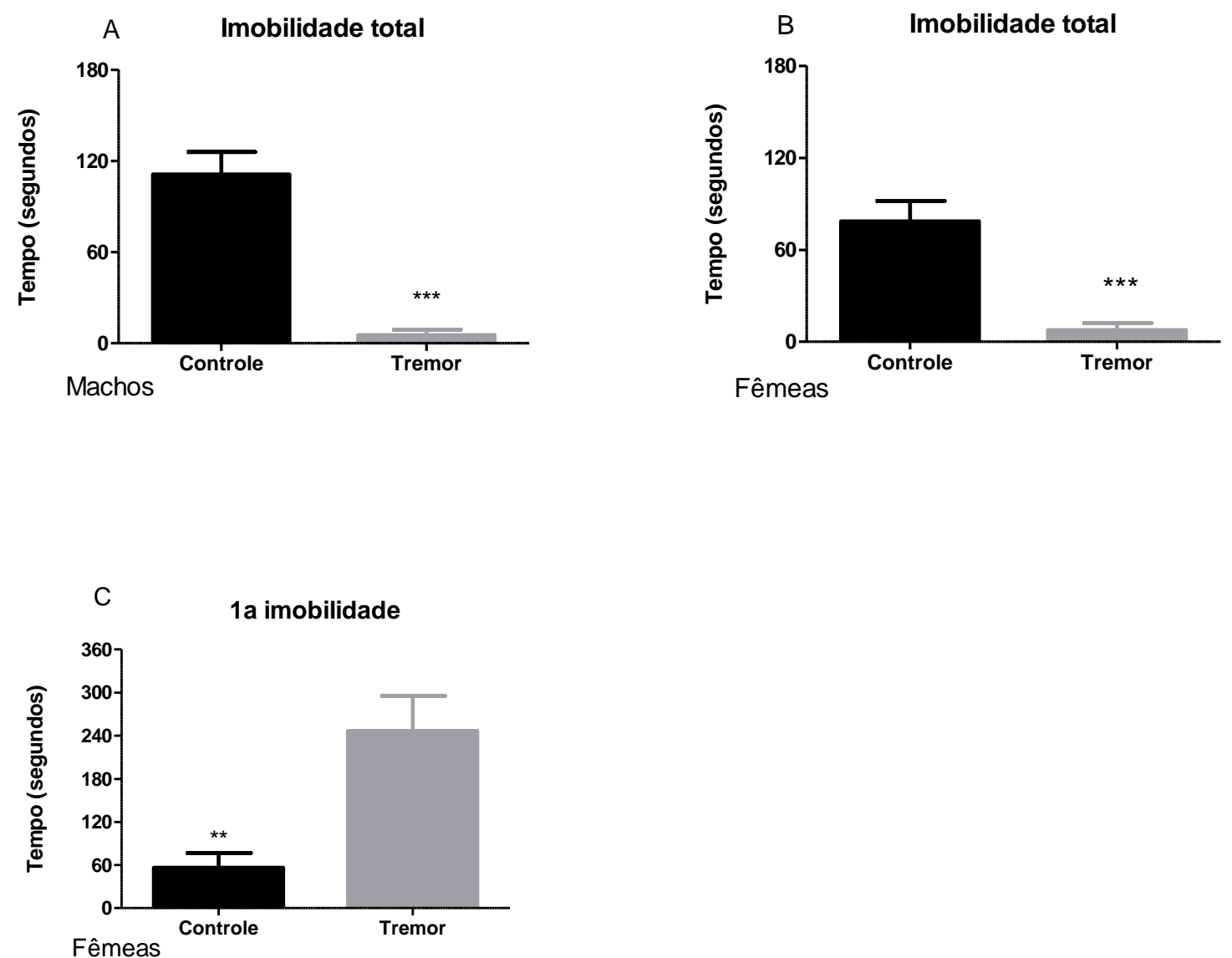

Fonte: (GARCIA-GOMES, 2017). 


\subsubsection{Suspensão pela cauda}

A tabela 9 mostra as respostas similares às de depressão dos camundongos machos e fêmeas mutantes tremor em fundo genético C57BL/6 e o respectivo grupo controle no teste de suspensão pela cauda. A partir da análise com o teste $t$ de Student não foram evidenciadas diferenças significativas no tempo de latência para a primeira imobilidade em nenhum dos grupos (machos: $p=0,9240 ; t=0,09716$; $d f=14$, fêmeas: $p=0,0814 ; t=1,8357 ; d f=22$, tabela 9), mas foram evidenciadas diferenças no tempo de imobilidade total dos dois grupos - machos $(p<0,0001$; $t=7,030 ; d f=14$, figura $16 A)$ fêmeas $(p<0,0001 ; t=11,80 ; d f=22$, figura $16 B)$.

Tabela 9 - Respostas no teste de suspensão pela cauda de camundongos C57BL/6 (controle) e C57BL/6 tremor machos e fêmeas. Os dados são apresentados em mediana (mínimo e máximo).

\begin{tabular}{|c|c|c|c|c|c|c|}
\hline Parâmetros & $\begin{array}{l}\text { C57BL/6 } \\
(n=8)\end{array}$ & $\begin{array}{l}\text { tremor }{ }^{\top} \\
(\mathrm{n}=8)\end{array}$ & Valor de $p$ & $\begin{array}{l}\text { C57BL/6우 } \\
(n=12)\end{array}$ & $\begin{array}{l}\text { tremor우 } \\
(n=12)\end{array}$ & Valor de $p$ \\
\hline $\begin{array}{l}\text { Latência para } \\
\text { a } 1^{\text {a }} \\
\text { imobilidade } \\
\text { (segundos) }\end{array}$ & $16,28 \pm 10,67$ & $17,43 \pm 9,85$ & 0,9716 & $15 \pm 11,55$ & $8 \pm 4,29$ & 0,0814 \\
\hline $\begin{array}{l}\text { Tempo total } \\
\text { de imobilidade }\end{array}$ & $185,71 \pm 25,12$ & $108,57 \pm 22,04$ & $<0,0001$ & $206 \pm 17,52$ & $99 \pm 24,52$ & $<0,0001$ \\
\hline
\end{tabular}

Fonte: (GARCIA-GOMES, 2017).

Figura 16 - Comportamento de camundongos C57BL/6 (controle) e C57BL/6 tremor machos e fêmeas no teste de suspensão pela cauda. Os dados são apresentados em média e respectivos errospadrão. Teste $T$ de Student. Machos: $n=8 /$ grupo, fêmeas: $n=12 /$ grupo. A e $B-{ }^{* * *} p<0,0001$

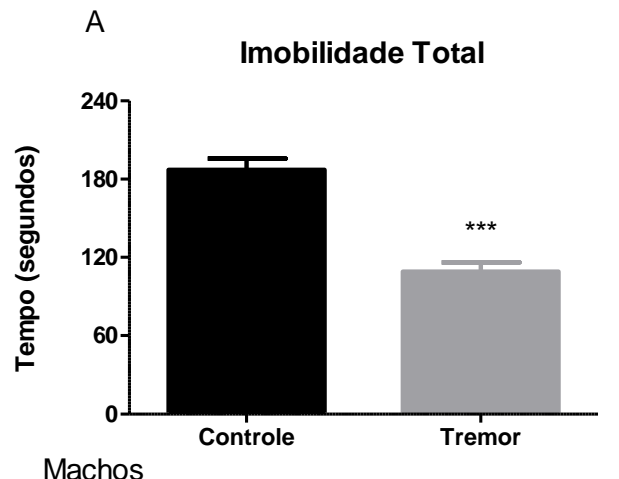

Machos

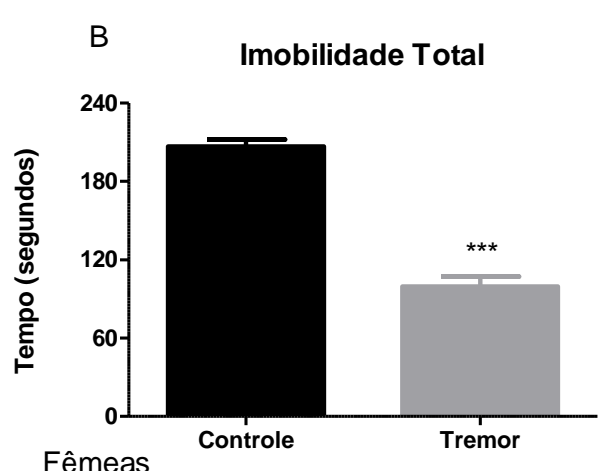

Fêmeas

Fonte: (GARCIA-GOMES, 2017). 


\subsection{DISCUSSÃO}

Um dos fatores relevantes na observação do comportamento do animal é a sua tendência a movimentar-se, conhecida como atividade geral. A quantificação dessa atividade por meio da locomoção e do levantar, considerados parâmetros exploratórios, podem também refletir aspectos de motricidade (BERNARDI e NETO, 1979, 1981). O comportamento de limpeza da face observado no campo aberto é tomado como a expressão de um decréscimo na emocionalidade e mostra não dependência das situações de medo (WALSH e CUMINNS, 1976).

Os resultados obtidos nos testes de atividade geral em campo aberto e de coordenação motora sugerem que os mutantes tremor possam apresentar deficiência na função espinocerebelar uma vez que esses parâmetros se mostraram reduzidos. Prosseguiu-se então um exame mais detalhado de outros parâmetros na tentativa de caracterizar o fenótipo comportamental dos camundongos mutantes. $\mathrm{Da}$ observação da atividade geral em campo aberto, pode-se depreender que a frequência de levantar e de grooming estavam reduzidas nos mutantes em relação ao grupo controle. No entanto, a redução tanto do levantar como da frequência de limpeza da face também poderia ser consequência de prejuízo na coordenação motora dos animais. De fato, o ato de levantar exige equilíbrio e movimentos coordenados para manter a postura; já a limpeza da face consiste de movimentos repetidos dos membros anteriores do animal em direção à face enquanto ele se apoia nos membros posteriores (KALUEFF, et. al., 2016). Os resultados observados na trave elevada concordam com esta hipótese, pois os camundongos mutantes atravessavam a trave com muita dificuldade e apresentaram redução nos escores em relação ao grupo controle. Os mutantes assumiam uma postura característica segurando-se com os membros anteriores e enrolando a cauda na trave para manter o equilíbrio. Ao atravessar, esses animais apoiavam o abdômen na trave e se arrastavam por toda a extensão da mesma, como foi ilustrado na figura 13B.

No parâmetro tempo de locomoção, os machos não apresentaram diferenças significativas entre os mutantes e seu respectivo grupo controle; porém as fêmeas apresentaram aumento significativo nesse parâmetro, que pode ser justificado pela diminuição da ansiedade ou pela hiperatividade desses animais. Nos testes de natação forçada e de suspensão pela cauda observou-se redução no tempo total de 
imobilidade dos camundongos tremor de ambos os sexos em relação ao grupo controle, que também pode ser interpretado como hiperatividade dos animais mutantes. Em um estudo realizado por Gallitano-Mendel et al. (2007), camundongos knockout para o gene Egr3 demostraram atividade locomotora aumentada em um ambiente novo, sugerindo que o Egr3 pode estar envolvido em alterações comportamentais, bem como nas respostas fisiológicas ao estresse.

Dentre os modelos para avaliação de medicamentos para tratamento de ansiedade destaca-se o labirinto em cruz elevada. Esse teste propõe que pequenos roedores, por terem aversão a espaços abertos devido à possibilidade de serem predados, permanecem e entram com menor frequência nos braços abertos do que nos braços fechados (KOMADA, et. al., 2008; PINTO et. al., 2012). No presente trabalho, nota-se redução tanto do número de entradas nos braços abertos quanto nos fechados dos camundongos mutantes em relação ao seu respectivo grupo controle. Por outro lado, o tempo de permanência nos braços não foi diferente entre os grupos. Visto que houve redução no número de entrada tanto nos braços abertos quanto nos fechados pode-se atribuir esse efeito a um prejuízo na função motora dos mutantes, previamente observada em outros testes, como o de atividade motora em campo aberto e de coordenação motora em trave elevada. No grupo das fêmeas foi observado aumento na porcentagem de entradas nos braços abertos e na porcentagem de tempo que os animais passavam nos braços abertos em relação aos braços fechados, o que concorda com a hipótese de haver uma redução da ansiedade desses animais em relação ao grupo controle, diferente do que havia sido observado nos testes com os camundongos machos. O segundo dia do teste na Cruz Elevada (que mediu a evocação da memória espacial dos animais) serviu para analisar se eles memorizaram o labirinto - que havia sido apresentado no dia anterior. A diminuição significativa nas porcentagens - de entradas e do tempo de permanência nos braços abertos - dos dois grupos comprova que não há déficit na formação ou na evocação da memória espacial dos camundongos tremor em relação aos camundongos controle em ambos os sexos.

O teste de alternância espontânea no labirinto em T (ou Y) avalia a memória operacional que está sob o controle de várias áreas corticais, principalmente o córtex occipital, frontal e parietal direito (SQUIRE e ZOLA, 1996). O teste da alternância espontânea é empregado para avaliar a aprendizagem operacional e requer que o animal escolha o braço oposto ao braço anteriormente escolhido. Os 
mutantes não apresentaram diferenças nas respostas neste teste comportamental quando comparados ao grupo controle, o que corrobora com a hipótese de que o camundongo tremor não apresenta déficit na formação ou na evocação da memória espacial e operacional; assim, é possível sugerir que alterações nas áreas corticais envolvidas com a memória operacional não tenham ocorrido nos mutantes. Esta é uma diferença entre o camundongo mutante espontâneo tremor e o camundongo mutante induzido knockout do gene Egr3, uma vez que esse último apresenta déficit de memória relacionada ao hipocampo - indicado pela diminuição no número de alternâncias no teste de memória do Labirinto em Y (GALLITANO-MENDEL, et. al. 2007). Li et al. (2007) observaram em seu estudo que apesar do camundongo knockout Egr3 apresentar desenvolvimento cerebral normal e sinapses normais nas áreas CA3 e CA1 do hipocampo - região na qual os neurônios apresentam alta expressão dos genes Egr1 e Egr3, esses animais apresentaram prejuízo evidente no aprendizado e memória, relacionado à dificuldade de reconhecer estímulos associativos; bem como deficiência na memória de curto e de longo prazo observada no teste de reconhecimento de objetos. Considerando isso é possível dizer que o gene Egr3 tem um papel muito importante no processo de aprendizagem e memória, e possivelmente na regulação de genes responsáveis pela formação e aquisição de memória. Na hipótese do candidato Egr3 ser o gene causador do fenótipo observado no camundongo tremor, esse déficit de memória do camundongo knockout ajuda a salientar a importância de se estudar as diferenças entre modelos induzidos e espontâneos, uma vez que o camundongo tremor não apresenta déficits de memória quando comparado aos camundongos controles.

Estudos realizados in vitro por Roberts et. al.(2005) comprovaram que o gene Egr3, quando transfectado em cultivo primário de neurônios do hipocampo, regula o neurotransmissor GABRA4p, aumentando sua atividade bem como os níveis das subunidades endógenas a4. Os camundongos knockout Egr3 apresentaram redução de $50 \%$ de RNA mensageiro de GABRA4, mas sem alterações na sua subunidade $\alpha$ mais abundante ( $\alpha 1$ ), o que sugere que o Egr3 tem um papel muito importante na formação do GABRA4 (ROBERTS et. al., 2005). Os autores também sugerem que o gene Egr3 controla a expressão das unidades a4 e exerce ação reguladora sobre o GABRA4 no desenvolvimento da epilepsia. A partir desse conhecimento, podemos propor novos estudos sobre a expressão gênica de Egr3 no SNC do mutante tremor 
visando esclarecer possíveis mecanismos envolvidos nas crises convulsivas observadas nesses animais.

A ausência de ataxia e o tremor de repouso são outras características que diferem o camundongo knockout Egr3 do mutante tremor (ROBERTS et. al., 2005). O mutante tremor apresentou tremor semelhante ao do camundongo knockout para o receptor a1 GABAa descrito por Kralic et. al. (2005), classificado como tremor postural e de movimento. Considerando esses dados podemos sugerir que 0 camundongo tremor tem características que o diferem do tremor presente na doença de Parkinson, que pode ser caracterizado como tremor de repouso; mas que assemelham-se ao tremor essencial; caracterizado por tremor de movimento (ou cinético) e postural (quando há uma tentativa do indivíduo de exercer uma força contra a gravidade e é gerada uma oscilação involuntária) (KRALIC, et. al. 2005).

Ainda sobre o estudo de Kralic et. al. (2005) a constatação mais importante é que a deleção da subunidade $\alpha 1$ dos receptores GABAa acaba por gerar tremores de postura e cinéticos (de movimento) exibidos pelos camundongos afetados com a mutação, assim como falta de coordenação motora, o que faz com que a doença se assemelhe muito à patologia do tremor essencial em humanos, o que seria de grande importância para a medicina, uma vez que os mecanismos da doença ainda não são bem elucidados e não existem modelos animais adequados ao seu estudo.

$\mathrm{Na}$ tentativa de encontrar modelos animais com características genéticas e fenotípicas que se assemelhem às doenças neurológicas em humanos, nossos resultados sugerem que o camundongo mutante espontâneo tremor possa servir como modelo para tais doenças; no entanto, sua caracterização ainda encontra-se na fase inicial. 


\section{CONCLUSÕES}

A partir dos objetivos pretendidos ao início do projeto, pudemos concluir que:

- O desenvolvimento pós-natal dos filhotes Swiss, físico e de reflexos, não apresentou diferenças entre os mutantes tremor e os controles, confirmando a hipótese inicial de que o fenótipo só pode ser reconhecido no momento do desmame, ou seja na $3^{\underline{a}}$ semana de vida.

- Os camundongos Swiss e C57BL/6 tremor apresentaram maior locomoção, porém menor frequência de grooming e de levantar, em relação aos camundongos controles, observados no teste de atividade geral em campo aberto.

- Os camundongos Swiss e C57BL/6 mutantes tremor apresentaram déficit na coordenação motora em relação aos camundongos controles, observado no teste de coordenação motora em trave elevada.

- Os camundongos Swiss e C57BL/6 mutantes tremor não apresentaram déficit de memória espacial em relação aos seus respectivos controles, como observado no teste de labirinto em T;

- Os camundongos Swiss e C57BL/6 tremor apresentam menos respostas similares às de ansiedade em relação aos animais controle, como observado no teste de labirinto em cruz elevada.

- Os camundongos Swiss e C57BL/6 mutantes tremor apresentaram maior movimentação em relação aos respectivos controles nos testes de natação forçada e suspensão pela cauda, o que pode ser interpretado como hiperatividade. 


\section{REFERÊNCIAS}

ALDER, S.; ZBINDER, G. Methods for the evaluation of physical, neuromuscular and behavioral development of rats in early postnatal period. In: NEUBERT, D.; MERKER, H. J.; KWASIGROCH, T. E. (Ed.). Methods in prenatal toxicology. Stuttgart: Thieme, 1977. p. 175-185.

BERNARDI, M. M.; NETO, J.P. Effects of abrupt and gradual withdrawal from longterm haloperidol treatment on open field behavior of rats. Pshycopharmacology, v. 65 , n. 3, p. $247-250,1979$.

BERNARDI, M.M.; NETO, J.P. Effects of single and long-term haloperidol administration on open field behavior of rats. Psychopharmacology, v. 73, p. 171 175, 1981.

BRITO, A. S. Manual de ensaios toxicológicos in vivo. Campinas. Unicamp. 1994. p- $15-21$.

BROOKS-KAYAL, A. R.; RAOL, Y. H.; RUSSEK, S. J. Alteration and Epileptogenesis Genes. Neurotherapeutics: The Journal of the American Society for Experimental NeuroTheurapeutics, v. 6, p. $312-318,2009$.

BULT, C. J.; EPPIG, J. T.; BLAKE, J. A.; KADIN,J. A.; RICHARDSON, J. E. The mouse genome database: genotypes, phenotypes, and models of human disease. Nucleic Acids Research, v. 41, D885 - D891, 2013.

CAN A., DAO D. T., ARAD M., TERRILLION C. E., PIANTADOSI S. C., GOULD, T. D. The Mouse Forced Swim Test. Journal of Visualized Experiments: JoVE, n. 59, e3638, p. 1-6, Jan., 2012a. doi:10.3791/3638

CAN A., DAO D. T., TERRILLION C. E., PIANTADOSI S. C., BHAT S., GOULD T. D. The Tail Suspension Test. Journal of Visualized Experiments: JoVE, n. 59, e3769, p. 1-5, Jan., 2012b. doi:10.3791/3769.

CoNeCte - Blog da Sociedade Brasileira de Neurociências e Comportamento. Stéfano Pupe. Softwares gratuitos para análisedo Labirinto em Cruz Elevado e Campo Aberto. 30.jul.2010. Disponível em < http://blog.sbnec.org.br/2010/07/softwares-gratuitos-para-analise-do-labirinto-emcruz-elevado-e-campo-aberto/>. Acesso em 10.mai.2017.

CRAWLEY,J. N. Behavioral phenotyping of rodents.Comp Med., v.53, n.2, p. 140 146, 2003.

CRAWLEY,J.N. Behavioral phenotyping strategies for mutant mice. Neuron, v. 57, p. $809-818,2008$.

DAPPER,J. D.;JUSTICE, M. J.Defining the breakpoints of the quaking(viable) mouse mutation reveals a duplication from a Parkin intron. Movement Disorders journal. v. 20, n. 10, p. 1369 - 1374, 2005. 
DEACON R. M. J. \& RAWLINS J. N. P. T-maze alternation in the rodent. Nature Protocols, v. 1, n. 1, p. 7-12, 2006. doi:10.1038/nprot.2006.2.

ETTINGER, S. J.; FELDMAN, E. C.Tratado de Medicina Veterinária: doenças do cão e do gato. São Paulo, Guanabara Koogan, 2004. 2236 p.

ESTORK, D.M.; GUSMAO, D.F.;PACIENCIA, M.L.B.;DIAZ, I.E.C.; VARELLA, A.D.; YOUNES, R.N.; REIS, L.F.L.; MONTERO, E.F.S.; BERNARDI, M.M.; SUFFREDINI, I.B. First chemical evaluation and toxicity of Casinga-cheirosa to Balb-c male mice. Molecules. v.19, p. $3973-3987,2014$.

FLANAGAN, S. P. 'Nude', a new hairless gene with pleiotropic effects in the mouse. Genetics Research, v. 8, n. 3, p. $295-309,1966$.

GALLITANO-MENDEL, A.; IZUMI, Y.; TOKUDA, K.; ZORUMSKI, C. F.; HOWELL, M. P.; MUGLIA, L. J.; WOZNIAK, D. F.; MILBRANDT, J. The immediate early gene Egr3 mediates adaptation to stress and novelty. Neuroscience, v. 148, n. 3, p. 633 643, 2007.

GUÉNET, J. L. Chemical mutagenesis of the mouse genome: an overview. Genetica. Paris, v. 122, p. 9 - 24, 2004.

GUÉNET, J. L. The mouse genome.Genome Research. Paris, v. 15, p. 1729 1740, 2005.

HOWNG, S. Y. B.; AVILA, R. L.; EMERY, B.; TRAKA, M.; LIN, W.; WATKINS, T.; COOK, S.; BRONSON, R.; DAVISSON, M.; BARRES, B. A.; POPKO, B. ZFP191 is required by oligodendrocytes for CNS myelination. Genes \& Development, v. 24, p. 1-11, Jan, 2010. doi: 10.1101/gad.1864510.

JACKSON LABORATORY. JAX Mice Pup Appearence by Age. Disponível em < http://jackson.jax.org/rs/444-BUH-304/images/LT0030_Mouse_Estrus-pups.pdf>.

Acesso em 10.mai.2017.

KALUEFF, A. V.; STEWART, A. M.; SONG, C.; BERRIDGE, K. C.; GRAYBIEL, A. M.; FENTRESS, J. C. Neurobiology of rodent self-grooming and its value for translational neuroscience. Neuroscience. v.17, p. $45-58,2016$.

KIM, S. H.; SONG, J. Y.; JOO, E-J.; LEE, K. Y.; AHN, Y. M.; KIM, Y.S. EGR3 as a Potential Susceptibility Gene for Schizophrenia in Korea. American Journal of Medical Genetics, part B, p. 1355 - 1360, 2010.

KOMADA, M.; TAKAO, K.; MIYAKAWA, T. Elevated Pluse Maze for Mice. Journal of Visualized Experiments, v. 22, e1088, 2008.

KRALIC, J. E.; CRISWELL, H. E.; OSTERMAN, J. L.; O'BUCLKEY, T. K.; WILKIE, M. E.; MATTHEWS, D. B.; HAMRE, K.; BREESE, G. R.; HOMANICS, G. E.; MORROW, A. L. Genetic essential tremor in $\gamma$-aminobutyric acid a receptor $\alpha 1$ subunit knockout mice. The Journal of Clinical Investigation, v.115, n. 3, p. 774 779, 2005. 
LI, L.; YUN, S. H.; KEBLESH, J.; TROMMER, B. L.; XIONG, H.; RADULOVIC, J.; TOURTELLOTTE, W. G. Egr3, as a synaptic activity regulated transcription factor that is essential for learning and memory. Molecular and cellular Neuroscience, $v$. 35 , n. 1, p. $76-88,2007$.

LISTER, R.G. Ethologically-based animal models of anxiety disorders; Pharmacology \& Therapeutics, v. 46, n. 3, p. 321 - 340, 1990.

LÓPEZ-LÓPEZ, D.; GÓMEZ-NIETO, R.; HERRERO-TURRIÓN, M. J.; GARCÍACAIRASCO, N.; SÁNCHEZ-BENITO, D.; LUDEÑA, M. D.; LÓPEZ, D. E. Overexpression of the immediate-early genes Egr1, Egr2 and Egr3 in two strains of rodents susceptible to audiogenic seizures. Epilepsy \& Behavior, 2016, 12p.

LORENZ, M. D.; KORNEGAY, J. N. Neurologia Veterinária. Barueri, Manole, 2006. $480 \mathrm{p}$.

LUONG T. N., CARLISLE H. J., SOUTHWELL A., PATTERSON P. H. Assessment of motor balance and coordination in mice using the balance beam. Journal of Visualized Experiments: JoVE, n. 49, e2376, p. 5-7, 2011. doi:10.3791/2376

MASSIRONI, S. M. G. Padrão Genético. In: LAPCHIK, V. B. V.; MATTARAIA, V. G. M.; KO, G. M. Cuidados e Manejo de Animais de Laboratório. São Paulo: Atheneu, 2009. P-385.

MENALLED, L. B.; CHESSELET, M.F. Mouse models of Huntington's disease. Trends in Pharmacological Science, v. 23, n. 1., p. 32 - 39, 2002.

MIWA, M. Rodents modelsof tremor. The Cerebellum, v. 6, p. 66 - 72, 2007. NAVE, K. A.Neurological mouse mutants and the genes of myelin.Journal of Neuroscience Research. v. 38, n. 6, p. $607-612,1994$.

NEVES, M. A. O.; MELlO, M. P.; DUMARD, R. S. A.; BOTELHO, J. P.; NASCIMENTO, O. J. M.; FREITAS, M. R. G. Abordagem fisioterapêutica na minimização dos efeitos da ataxia em indivíduos com esclerose múltipla. Revista Neurociências, v. 15, n.2, p. $160-165,2007$.

O'SHAUGHNESSY, P. J.; SHEFFIELD, J. W. Effect of temperature and the role of testicular descent on post-natal testicular androgen production in the mouse. Journals of Reproduction \&FertilityLtd., v.91, p. 357 - 364, 1991.

PINTO, W.B.V.R.; KO, G.M.; VALERO-LAPCHIK, V.B.; ARIZA, C.B.; PORCIONATTO, M. Teste de labirinto em cruz elevado: aplicações e contribuições no estudo de doenças neuropsiquiátricas em modelos animais. RESBCAL, São Paulo, v.1 n.1, p. 102 - 120, 2012.

PINTO, W. B. V. R.; SOUZA, P. V. S.; KO,G. M. Exame neurológico do camundongo. RESBCAL, v.2 n.3, p. 222 - 227, 2013. 
RICCI, E. L.;BERNARDI, M. M.; GÓRNIAK, S. L.; SPINOSA,H. S. Behavioral teratogenicity induced by maternal food restriction: maternal cannibalism and poor reflex development in offspring. Biotemas, v. 27, n. 2, p. 185 - 192, 2014.

ROBERTS, D. S.; RAOL, Y. H.; BANDYOPADHYAY, S.; LUND, I. V.; BUDRECK, E. C.;PASSINI, M. A.; WOLFE, J. H.; BROOKS-KAYAL, A. R.; RUSSEK, S. J. Egr3 stimulation of GABRA4 promoter activity as a mechanism for seizure-induced upregulation of GABAa receptor $\alpha 4$ subunit expression. Proceedings of the National Academy of Sciences, v.102, n. 37, p. $11894-11899,2005$.

RUBERT, V. A.; REIS, D. C.; ESTEVES, A. C. Doença de Parkinson e exercício físico. Revista Neurociências, v. 15, n.2, p. 141 - 146, 2007.

SQUIRE, L.R.; ZOLA, S.M.. Structure and function of declarative and non-declarative memory system. Proceedings of the National Academy of Sciences of the United States of America, v.93, n. 24, p. 13515 - 13522, 1996.

SWEET, H. O.; BRONSON, R. T.; JOHNSON, K. R.; COOK, S. A.;DAVISSON, M. T.Scrambler, a new neurological mutation of the mouse with abnormalities of neuronal migration. Mammalian Genome. v. 7, p. 798 - 802, 1996.

TATEM, K. S.; QUINN, J. L.; PHADKE, A.; GORDISH-DRESSMAN, H.; NAGARAJU, K. Behavioral and Locomotor Measurements Using na Open Field Activity Monitoring System for Skeletal Muscle Diseases. Journal of Visualized Experiments, v. 91, e51785, 2014.

TOURTELLOTTE, W. G.; MILDBRANDT, J. Sensory ataxia and muscle spindle agenesis in mice lacking the transcription fator Egr3. Nature Genetics, v.20, p. 87 91, 1998.

WALSH, R. N.; CUMINNS, R.A. The open-field test: a critical review. Psychological Bulletin, v. 83, n. 3, p. $482-504,1976$. 